EUDER GLENDES ANDRADE MARTINS

\title{
O Clado Urticóide (Rosales) na Flora da Serra do Cipó, Minas Gerais.
}

São Paulo

2009 


\section{EUDER GLENDES ANDRADE MARTINS}

\section{O Clado Urticóide (Rosales) na Flora da Serra do Cipó, Minas Gerais.}

Dissertação apresentada ao Instituto de Biociências da Universidade de São Paulo, para a obtenção do Título de Mestre em Ciências, na Área de Botânica.

Orientador(a): José Rubens Pirani 


\section{Ficha Catalográfica}

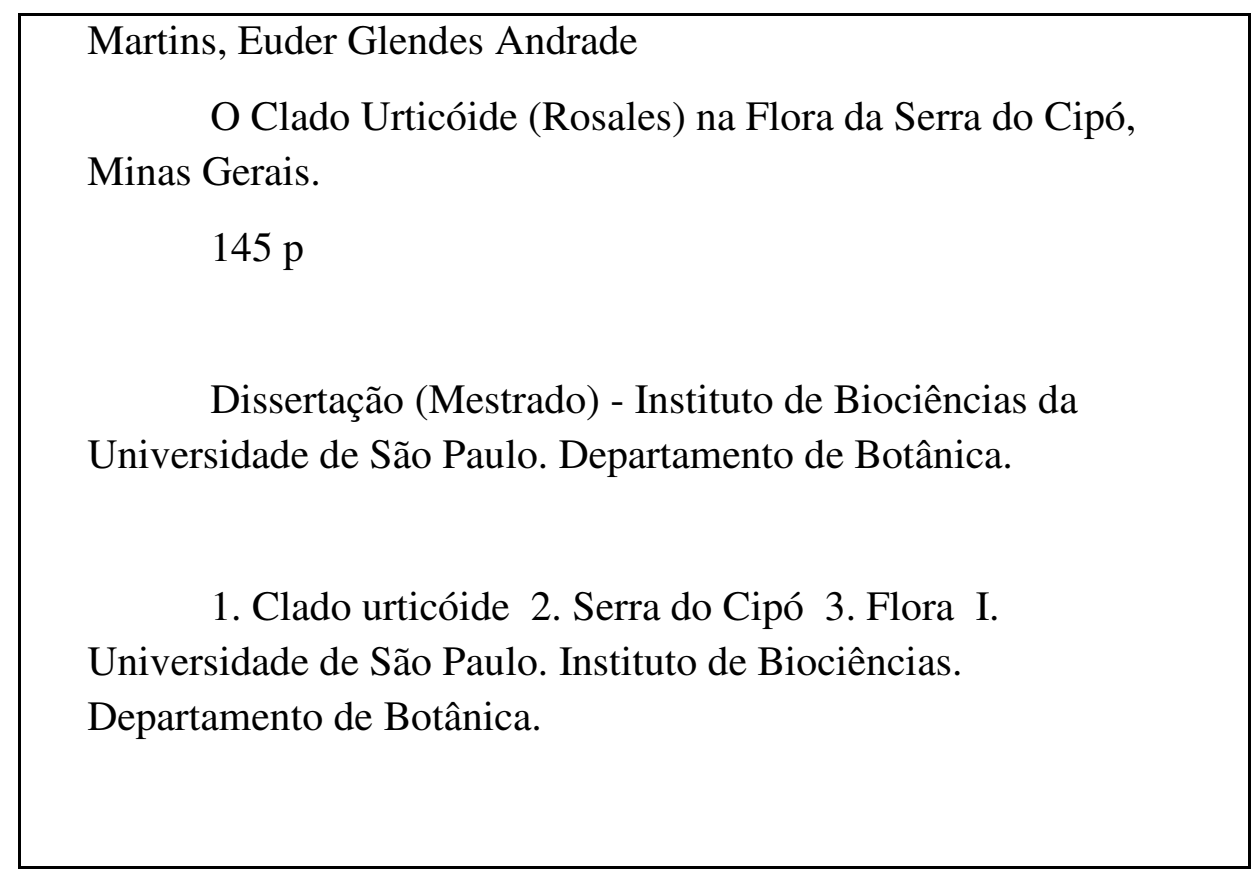

Comissão Julgadora:

Prof(a). Dr(a).

Prof(a). Dr(a).

Prof(a). Dr.(a).

Orientador(a) 
Aos meus pais. Francisca Maia Martins e Luzanira, aos meus irmãas. Helder. Maia e Jaíra, e aos meus queridas sobrinhos, kerlândia. Marcela. Kerliane. Marlan. Caia e Cira Or. por toda apaia e carinha, pela paciência, compreensãa e pela saudade em minha ausência, dedica. 
Sau imensamente grato a tadas as instituiçäes e pessoas que, direta ou indiretamente contribuiram cam este trabalho.

Agradeça an meu Orientador Prof. Dr. Dasé Rubens Pirani, par toda apaia e confianca. pelas ensinamentos. símbala de dedicaçãa e disciplina. e pela opartunidade de realizar este trabalho.

to CNPq e CEPSMA-USP pelas bolsas concedidas e pela apoia financeira.

ta Prof. Dr. RamiraV. Camacha pela estímula, amizade, par ter me apresentada à "Batânica" e mostrada a caminha da pesquisa na USP par meia da Profa. Dra. Marica Megura, a qual sou gentilmente grato por ter aberta as portas deste Instituta $e$. principalmente, pela articulaçãa junta as Prof. Pirani.

Aos curadores dos herbários visitados, que enviaram as materiais para meu estuda.

ta Prof. Dr. Sergia Ramaniuc-Neta, especialista na grupa urticáide, pela esclarecimenta e sugestaes de leitura sobre a grupa urticaide repassados quanda membra da banca de meu Exame de Zualificaçãa, assim coma pelas discussäes pasteriores e colabaraçãa cam este trabalho.

Aos Profs. Renata Mella-Silua. Lúcia Lohmann. Nanuza e Paula Takea Sano. por estarem sempre dispostos a tirar minhas dívidas. Ao Prof. Dr. Pacula Takea pelas belas viagens a Serra da Cipá. pelos ensinamentos, pela amizade e pelos bans momentos de descontraçãa, agradeça.

Aa Abel pela montagem e preparaçãa dos materiais e par aquele "santo" cafezinha do dia-a-dia. Ȧ Fabiana Begale pela auxilia nas solicitaçöes de empréstimas e devaluçäes dos materiais, e pela companhia e ajuda em viagem de coleta.

Ao Norberta. Helder e Érika, por estarem sempre dispostos a tirar dívidas e a resolver as problemas administrativas.

À tadas meus calegas da Labaratária de Sistemática Vegetal: Alice. Anselma. Benoît. Bia. Caral Mittelstaedt. Carol Lopez. Cintia. Cristina Sato. Dayane. Eduarda Faresta (Dudu). Ellen. Fäbia. Flácia. Gisele. Herbet (Dr. Fiqueira), Tsabel. Jenifer (JeLa). Du Randa. Iu El Ottra. Ju Paula-Sauza, Ĺuia. Luiz. Marcela. Mariana. Mariane, Maura. Mauricia (Muricia), Miriam. Patricia, Paula, Pedra Dias. Suzana e Vânia, agradeça pelas momentos compartilhados, pelas viagens de coleta, pela atençäa e boa contade que me atenderam em todas as vezes que precisei. À qu Lava. Maria Fernanda $e$ Farinaccia agradeça pela apoia, amizade e conselhos dados aa langa desse períado de trabalha: as Caqui (Leanarda) par estar sempre dispasta a un "\#elp tecnológica"; aa Baza (Matheus) par ter me apresentado a face leste da Serra da Cipá (Cabeça de Boi) e pela grande "ajuda" as meu trabalha; as Trová (Marcela) e Assis (Leandra) pelas conversas $e$ "papas filasóficas e de descantraçãa" da dia-a-dia, agradeça.

E a Ana Maria Barbieri Bedran, pela companhia, carinho, apoia, afeto e estímula que muita me fortaleceu a enfrentar este $e$ outros abstáculas durantes esses ciltimos anos $e$. principalmente, agradeça pela compreensãa e amor a mim confiados. 


\section{ÍNDICE}

página

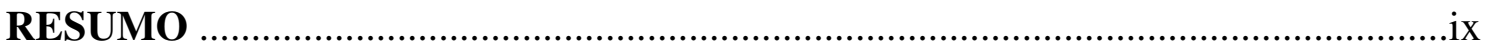

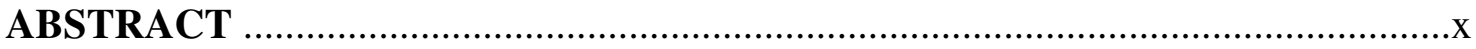

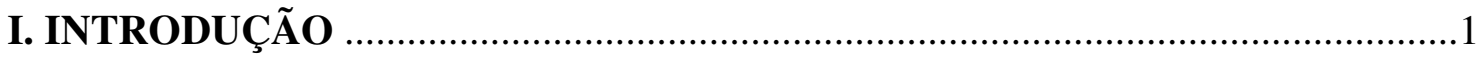

I.1. O CLADO URTICÓIDE (ROSALES) ......................................................

I.2. ESTUDOS NA FLORA DA SERRA DO CIPÓ ............................................7

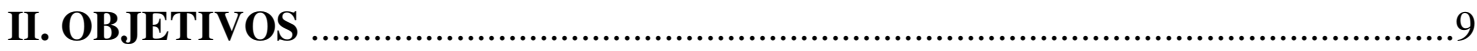

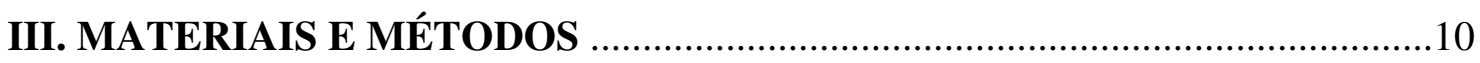

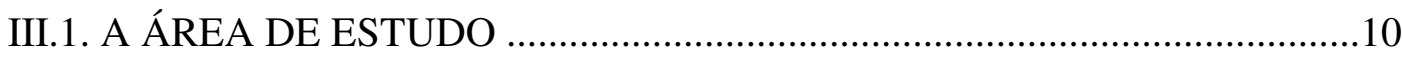

III.2. LEVANTAMENTO DAS ESPÉCIES ….................................................16

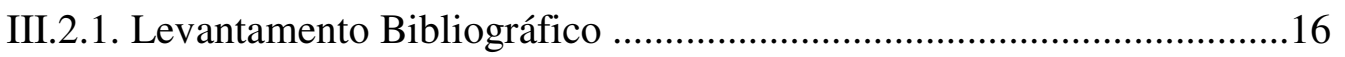

III.2.2. Coleta e Conservação do Material ......................................................16

III.2.3. Consultas aos Herbários e Material Analisado.......................................18

III.2.4. Análise e Identificação do Material ......................................................20

III.2.5. Apresentação das Espécies .................................................................21

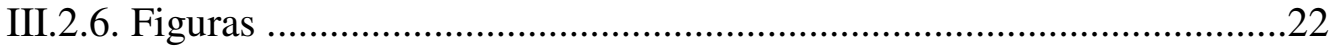

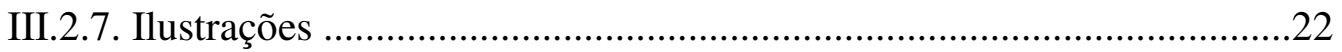

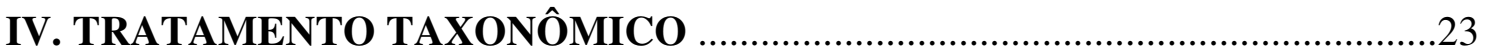

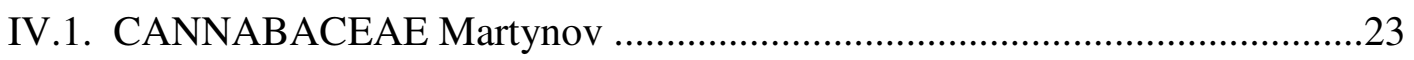

Chave para os gêneros presentes na Serra do Cipó ..........................................25

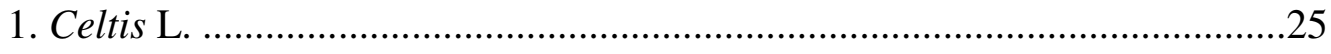

1.1. Celtis iguanaea (Jacq.) Sarg. ..........................................................27

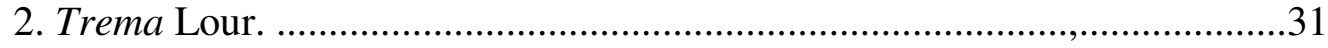

2.1. Trema micrantha (L.) Blume .............................................................32

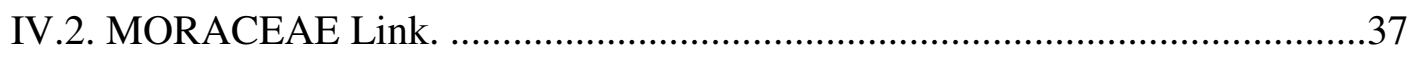

Chave para os gêneros presentes na Serra do Cipó ...........................................39

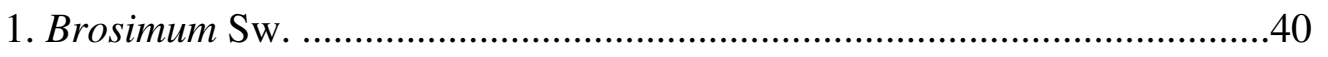

1.2. Brosimum gaudichaudii Tréc. ...........................................................41

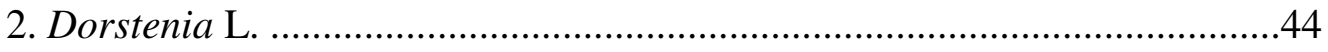

2.1. Dorstenia brasiliensis Lam. .........................................................45

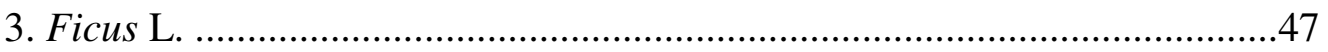

Chave para as espécies de Ficus presentes na Serra do Cipó ........................49 
3.1. Ficus calyptroceras (Miq.) Miq. …...................................................50

3.2. Ficus gomelleira Kunth \& C.D. Bouché ...........................................53

3.3. Ficus obtusifolia Kunth ....................................................................56

3.4. Ficus obtusiuscula (Miq.) Miq. ......................................................61

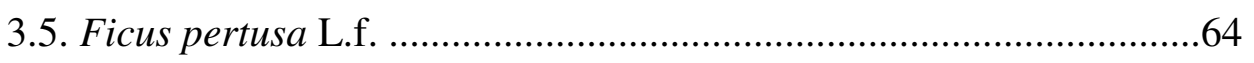

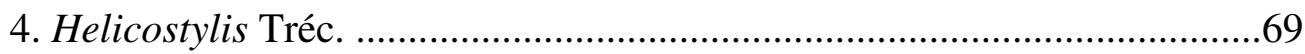

4.1. Helicostylis tomentosa (Poepp. \& Endl.) Rusby ...............................70

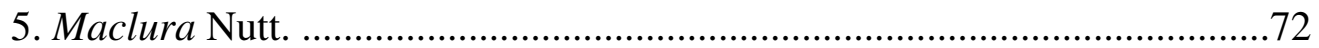

5.1. Maclura tinctoria (L.) D. Don ex Steud. ..........................................73

6. Pseudolmedia Tréc. .....................................................................................76

6.1. Pseudolmedia laevigata Tréc. .......................................................77

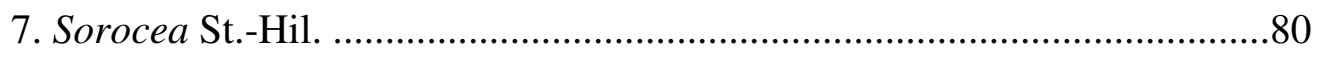

7.1. Sorocea guilleminiana Gaudich. ...................................................81

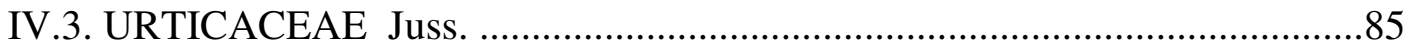

Chave para os gêneros presentes na Serra do Cipó .........................................88

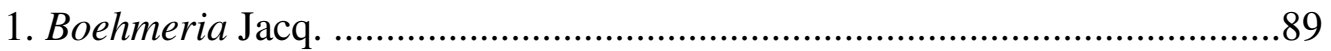

1.1. Boehmeria caudata Sw. ................................................................90

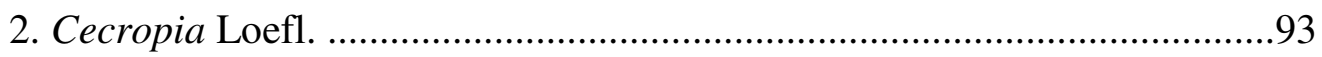

Chave para as espécies de Cecropia presentes na Serra do Cipó ....................96

2.1. Cecropia hololeuca Miq. in Martius ...................................................96

2.2. Cecropia pachystachya Tréc. ..........................................................99

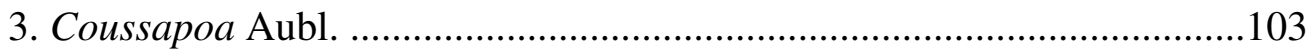

3.1. Coussapoa microcarpa (Schott) Rizzini ........................................105

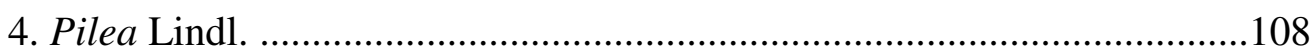

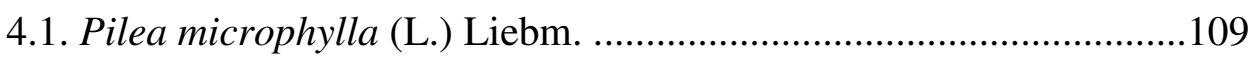

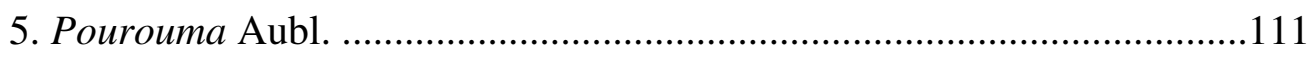

5.1. Pourouma guianensis Aubl. ..........................................................114

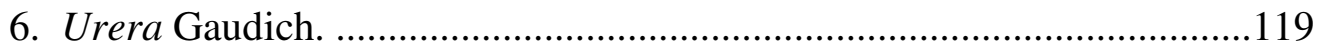

6.1. Urera baccifera (L.) Gaudich. ......................................................120

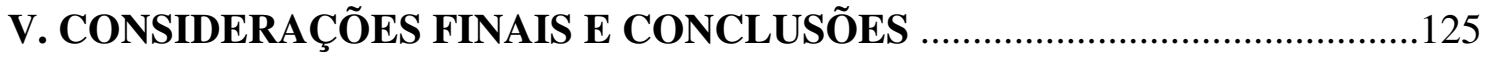

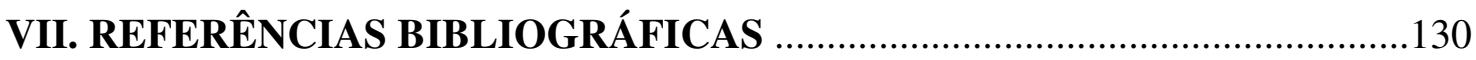


Figura 1: Características diagnósticas do clado urticóide da ordem Rosales .5

Figura 2: Posicionamento e relacionamento filogenético das famílias urticóides 6

Figura 3: Mapa da Cadeia do Espinhaço, com os topônimos principais e destaque para a Serra do Cipó

Figura 4: Mapa da Serra do Cipó, destacando as principais localidades, vias de acesso e as maiores altitudes 13

Figura 5: Mapa detalhado do Parque Nacional da Serra do Cipó .14

Figura 6: Paisagens encontradas na Serra do Cipó e principais habitas das espécies urticóides .15

Figura 7: Ilustrações de Celtis iguanaea e Trema micrantha .35

Figura 8: Ilustrações de Dorstenia brasiliensis, Ficus Calyptroceras e F. obtusifolia 59

Figura 9: Ilustrações de Ficus gomelleira, F. obtusiuscula e F. pertusa .67

Figura 10: Ilustrações de Brosimum gaudichaudii e Pseudolmedia laevigata .79

Figura 11: Ilustrações de Helicostylis tomentosa, Maclura tinctoria e Sorocea guilleminiana .83

Figura 12: Ilustrações de Cecropia pachystachya, Coussapoa microcarpa e Pourouma guianensis

Figura 13: Ilustrações de Boehmeria caudata, Pilea microphylla e Urera baccifera 124

\section{ÍNDICE DE TABELAS}

página

Tabela 1: Comparações morfológicas de Cannabaceae, Moraceae e Urticaceae ............7

Tabela 2: Período das expedições de coletas e as respectivas áreas visitadas 17

Tabela 3: Habitats preferenciais das espécies do clado urticóides ocorrentes na Serra do Cipó .128 


\section{RESUMO:}

Este trabalho tem como objetivo principal contribuir para o conhecimento da flora da Serra do Cipó, Minas Gerais, através do estudo taxonômico das espécies do clado urticóide da ordem Rosales ocorrentes na área. Esse grupo compreende cerca de 110 gêneros e aproximadamente 4000 espécies distribuídas nas famílias Ulmaceae, Cannabaceae, Moraceae e Urticaceae, diagnosticados pela presença de cistólitos, flores reduzidas e inconspícuas com 5 ou menos estames e gineceu bicarpelar com ovário unilocular portando um único óvulo apical ou basal. O levantamento das espécies urticóides foi realizado baseando-se em consultas bibliográficas, visitas aos principais herbários com coleções de materiais da Serra do Cipó, expedições de coleta aos principais pontos amostrados e exploração de novas áreas. Na Serra do Cipó foram encontrados 15 gêneros e 20 espécies distribuídas da seguinte maneira: duas espécies em Cannabaceae Martynov - Celtis iguanaea (Jacq.) Sarg. e Trema micrantha (L.) Blume; 11 em Moraceae Link. - Brosimum gaudichaudii Tréc., Dorstenia brasiliensis Lam., Ficus calyptroceras (Miq.) Miq., F. gomelleira Kunth \& C.D. Bouché, F. obtusifolia Kunth, F. obtusiuscula (Miq.) Miq., F. pertusa L.f., Helicostylis tomentosa (Poepp. \& Endl.) Rusby, Maclura tinctoria (L.) D. Don ex Steud., Pseudolmedia laevigata Tréc. e Sorocea guilleminiana Gaudich.; e sete em Urticaceae Juss., sendo elas: Boehmeria caudata Sw., Cecropia hololeuca Miq., C. pachystachya Tréc., Coussapoa microcarpa (Schott) Rizzini, Pilea microphylla (L.) Liebm., Pourouma guianensis Aubl. e Urera baccifera (L.) Gaudich. São apresentadas descrições morfológicas, chaves de identificação de gêneros e espécies, ilustrações, dados sobre fenologia, distribuição geográfica, habitats e comentários sobre as espécies estudadas. 


\section{ABSTRACT:}

This work has as main objective to contribute for knowledgement of the "Flora da Serra do Cipó, Minas Gerais", through the taxonomic study of the species of urticalean clade of order Rosales in this area. This group includes about 110 genera and approximately 4000 species distributed in families Ulmaceae, Cannabaceae, Moraceae and Urticaceae, diagnosticated to presence of cystolithes, reducted and inconspicuous flowers with five or fewer stamens, two carpels gynoecium and unilocular ovary with a single apical or basal ovule. The taxonomic study of urticoid was carried out based on bibliographical consultations, in field activities and visits in the main herbaria with collections of material from Serra do Cipó. They were found 15 genera and 20 species of urticoide in Serra do Cipo, MG, like this distributed: two species of Cannabaceae Martynov - Celtis iguanaea (Jacq.) Sarg. and Trema micrantha (L.) Blume; 11 species of Moraceae Link. - Brosimum gaudichaudii Tréc., Dorstenia brasiliensis Lam., Ficus calyptroceras (Miq.) Miq., F. gomelleira Kunth \& C.D. Bouché, F. obtusifolia Kunth, F. obtusiuscula (Miq.) Miq., F. pertusa L.f., Helicostylis tomentosa (Poepp. \& Endl.) Rusby, Maclura tinctoria (L.) D. Don ex Steud., Pseudolmedia laevigata Tréc. and Sorocea guilleminiana Gaudich.; and seven species of Urticaceae Juss., being them Boehmeria caudata Sw., Cecropia hololeuca Miq., C. pachystachya Tréc., Coussapoa microcarpa (Schott) Rizzini, Pilea microphylla (L.) Liebm., Pourouma guianensis Aubl. and Urera baccifera (L.) Gaudich. Morpholological descriptions, identification key of genera and species, illustrations, notes on phenology, geographic distribution, habitats information and general comments about species studied are provided. 


\section{INTRODUÇÃO:}

\section{I.1. O CLADO URTICÓIDE (ROSALES):}

O clado urticóide (também referenciado como "Rosales urticóides", "rosídeas urticóides" ou simplesmente "grupo urticóide") compreende cerca de 110 gêneros e 4000 espécies distribuídas pelas famílias Ulmaceae, Cannabaceae, Moraceae e Urticaceae (Stevens, 2001). O clado é comumente diagnosticado e caracterizado por um conjunto marcante de sinapormorfias, destacando-se a presença de cistólitos globosos a alongados (concreções de carbonato de cálcio, dentro de idioblastos especializados denominados de litocistos), flores reduzidas e inconspícuas com 5 ou menos estames e gineceu bicarpelar com ovário unilocular portando um único óvulo apical ou basal (Humphries \& Blackmore, 1989; Judd et al., 1994) (figura 1).

Estas famílias, que incluem as figueiras, amoreiras, embaúbas e urtigas, foram por muito tempo tratadas como Ordem Urticales (Engler, 1964; Cronquist,1981, 1988; Dahlgren, 1989) baseados nos caracteres morfológicos supra-citados e em aspectos anatômicos do pólen e da flor. Wolfe (1974) ressaltava ainda o característico padrão de venação foliar, e, como Cronquist (1988), posicionou as Urticales junto ao grupo das Amentíferas como Fagaceae e Betulaceae, classificadas na subclasse Hamamelidae (Judd et al., 2002).

Porém a riqueza de novos dados moleculares tem colocado as famílias da linhagem urticóide dentro da ordem Rosales (figura 2-A), no clado das Eurosídeas I (sensu APG, 1998, incluindo Barbeyaceae, Dirachmaceae, Elaeagnaceae, Rhamnaceae e Rosaceae), sendo confirmados por meio das amplas análises feitas em angiospermas usando dois (Savolainen et al., 2000a) ou três marcadores moleculares (Soltis et al., 2000). Recentes análises em Eudicotiledôneas usando rbcL (Savolainen et al., 2000b) atestaram a monofilia da linhagem urticóide dentro das Rosales, embora seu relacionamento com os outros membros da ordem tenha ainda alguns resultados conflitantes (Thulin et al., 1998; Richardson et al., 2000; Kravtsova \& Oskolski, 2007).

Não obstante, o relacionamento filogenético das famílias urticóides apresenta-se ainda controvertido entre vários autores (Humphries \& Blackmore, 1989; Judd et al., 1994; Zavada \& Kim, 1996; Berg, 2001; Romaniuc-Neto, 1999; Nylin \& Wahlberg, 2008) 
(figura 2-B). A filogenia sugerida por Song et al. (2002) e Sytsma et al. (2000; 2002) considera Cannabaceae dentro de Celtidaceae (e.g. Ueda et al., 1997; no entanto, Cannabaceae é um nomen conservadum) e que Moraceae e Urticaceae são fortemente monofiléticos, desde que Cecropiaceae seja incluída dentro das Urticaceae s.l.

Ulmaceae é provavelmente o grupo-irmão do clado Cannabaceae + Moraceae + Urticaceae s.l. (Stevens, 2001; Kravtsova \& Oskolski, 2007). Este clado é caracteristicamente diagnosticado pela presença de flores unissexuadas e embriões curvos. Celtidaceae foi muitas vezes incluída dentro de Ulmaceae (e.g. Cronquist, 1981), criando-se assim um grupo parafilético. Omori \&Terabayashi (1993) e Terabayashi (1991) distinguiram Celtidaceae de Ulmaceae pelo padrão de venação foliar, morfologia floral, anatomia, tipo de fruto e pelas formas do embrião e do pólen, enquanto Sytsma et al. (2002) consideraram as flores unissexuadas, o embrião curvo e o hipanto reduzido como sinapormorfias de todas as Rosales urticóides excetuando as Ulmaceae. Assim a circunscrição tradicional de Ulmaceae foi profundamente reduzida com os recentes estudos em filogenia, tendo sido excluídos desta família gêneros como Celtis L. e Trema Lour., reconhecidos agora em Cannabaceae.

As Cannabaceae apresentam distribuição cosmopolita, incluindo 11 gêneros e cerca de 170 espécies, mais da metade pertencente ao gênero Celtis. Nesta família estão incluídas 2 gêneros que nas palavras de Mabberley (1997), "causam grande felicidade (e infelicidade) ao Homem". São eles Cannabis L., gênero monotípico ( $C$. sativa L.), de onde se extrai a maconha e haxixe, e Humulus L., gênero ao qual pertence o lúpulo (H. lupupus L.), que é um dos componentes utilizados na fabricação da cerveja (Souza \& Lorenzi, 2008). Na flora neotropical, os gêneros mais comuns são Celtis e Trema, muito frequentes em diversos tipos de vegetações brasileiras.

Moraceae e Urticaceae s.l. são as maiores famílias do clado urticóide, incluindose na primeira 37 gêneros e cerca de 1100 espécies, e aproximadamente 54 gêneros e 2600 espécies em Urticaceae (Berg, 2001; Stevens, 2001), ambas apresentando distribuição predominantemente tropical e subtropical, com algumas espécies nas regiões temperadas. Na região neotropical ocorrem cerca de 20 gêneros e 250 espécies, a maioria na região amazônica. Entre as espécies de maior interesse econômico destacam-se em Moraceae o figo (Ficus carica L.), a jaca (Artocapus 
heterophyllus Lam.), a fruta-pão (Artocapus altilis (Parkinson) Fosberg) e amora (Morus ssp.), e em Urticaceae o rami (Boehmeria nivea (L.) Gaudich.) (Souza \& Lorenzi, 2008).

A variação biogeográfica e morfológica é grande dentro das famílias urticóides e indubitavelmente tem contribuído para as diversas controvérsias sobre a circunscrição deste grupo, principalmente em relação à posição do grupo de gêneros próximos a Cecropia, como família distinta ou não das Moraceae e Urticaceae (Berg, 1989; Romaniuc-Neto, 1999; Kravtsova \& Oskolski, 2007; Smith \& Donoghue, 2008). No presente trabalho adota-se a circunscrição de famílias proposta nos trabalhos mais recentes, como grupos monofiléticos sustentados por evidências filogenéticas robustas, ficando os gêneros antes posicionados em Cecropiaceae incluídos entre as Urticaceae. As principais diferenças e semelhanças morfológicas observadas entre as três famílias urticóides tratadas no presente trabalho concentram-se em caracteres como o hábito, distribuição do látex, presença de cistólitos alongados, estames, estigma e posição do óvulo (Tabela 1).

No entanto, o clado de modo geral exibe grande variação na forma de crescimento das espécies que inclui os hábitos leptocaule e paquicaule, árvores perenes ou decíduas, arbustos, trepadeiras, hemiepífitas, subarbustos e ervas, estas últimas compreendendo várias espécies suculentas e anuais. As folhas variam marcadamente, frequentemente com venação broquidódroma ou actinódroma. Células mucilaginosas e canais secretores são comuns em Moraceae e Urticaceae. As flores são bissexuadas ou mais comumente unissexuadas, polinizadas por insetos ou pelo vento. A variação na estrutura do gineceu e na configuração do estame é grande, bem como a maneira de liberação do polén (Berg, 1989). Ocorre também uma grande variação na estrutura da inflorescência, existindo racemos, espigas, cimeiras e uma série de especializações relacionadas a redução floral e adensamento ou união, sendo muito características como os cenantos e sicônios de alguns gêneros de Moraceae. A dispersão dos frutos e sementes também mostra ampla variação, sendo a anemocoria (dispersão pelo vento) comum em Ulmaceae e Urticaceae; a hidrocoria está presente em algumas Moraceae e Urticaceae; a dispersão zoocórica é característica das Celtidaceae, Moraceae e Urticaceae (Berg, 2001).

O estado de conhecimento das Rosales urticóides no Brasil está muito aquém do necessário para que se possa avançar nos estudos de filogenia e biogeografia do 
grupo, e assim garantir a sua conservação biológica. Destacam-se os trabalhos de Miquel (1853) sobre Urticinae na Flora Brasiliensis de Martius, as monografias mais recentes de Berg para a série Flora Neotropica (Berg, 1972, 1990, 2001; Berg \& Franco-Rosselli, 2005), as várias contribuições de Carauta (e.g. 1968, 1976, 1989) e ainda um livro ricamente ilustrado das figueiras no país (Carauta \& Diaz, 2002) e os trabalhos desenvolvidos por Romaniuc-Neto $(1998,1999)$, assim como as contribuições de Mendonça-Souza (2006), de Castro (2006), Martins et al. (2007), dentre outros. Dessa maneira, a grande necessidade de implementar mais estudos florísticos e taxonômicos no grupo foi a primeira força que motivou a proposta do presente trabalho. 

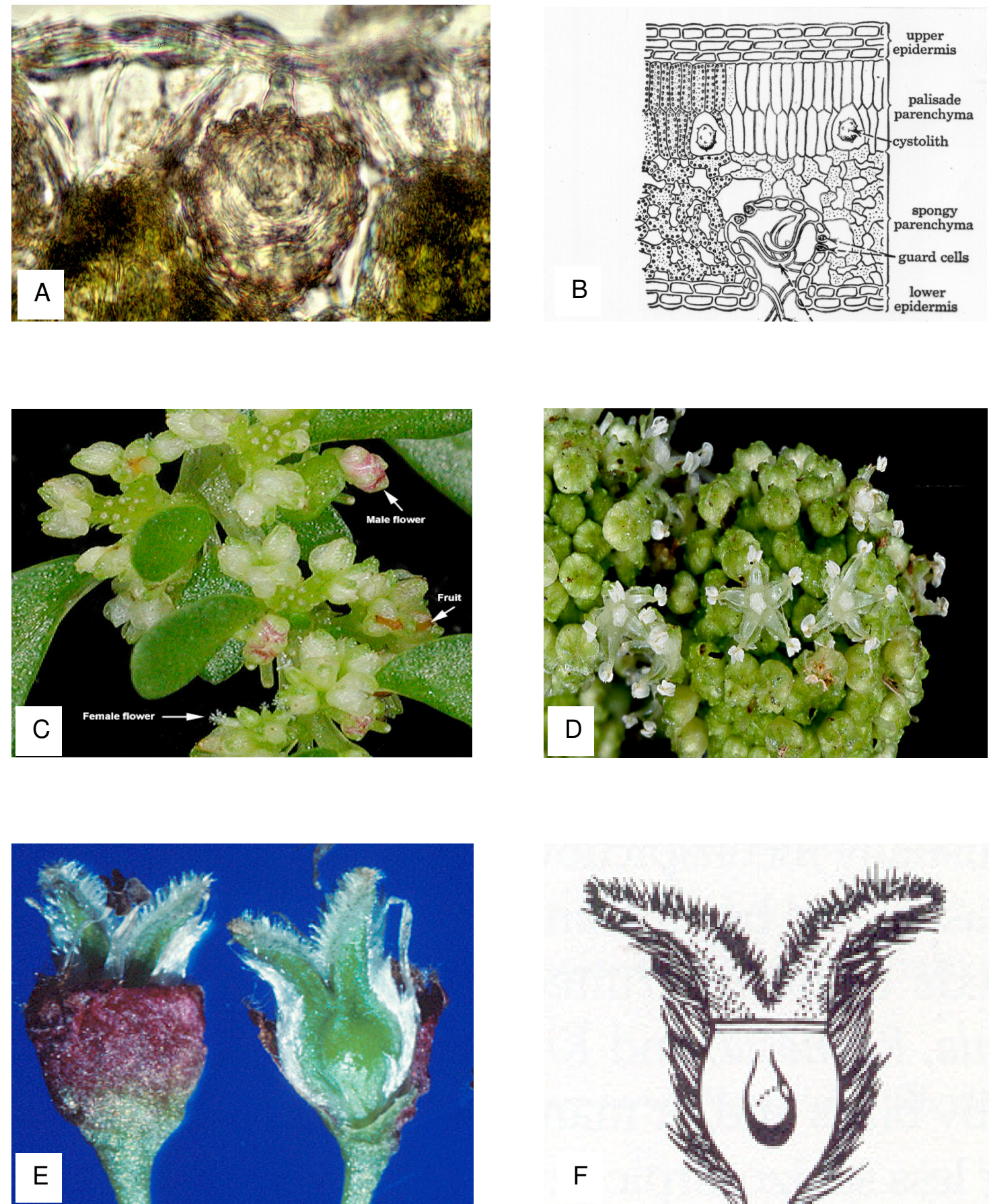

Figura. 1: Características diagnósticas do clado urticóide. A - cistólitos globosos no interior de litocistos (Boehmeria caudata Sw.); B - desenho esquemático da epiderme foliar mostrando cistólito globoso mergulhado no parênquima paliçádico (Ficus elastica Roxb.; adaptado de Robbins \& Weier (1950)); C - flores reduzidas ou inconspícuas (Pilea microphylla (L.) Liebm.; D - estames em número de 5 ou menos e opostos ao perianto (Urticaceae); E - gineceu bicarpelar (Ulmus, Urticaceae); F - ovário unilocular portanto um único óvulo apical (Ulmus sp; adaptado de Kubitzki et al. (1993)). 

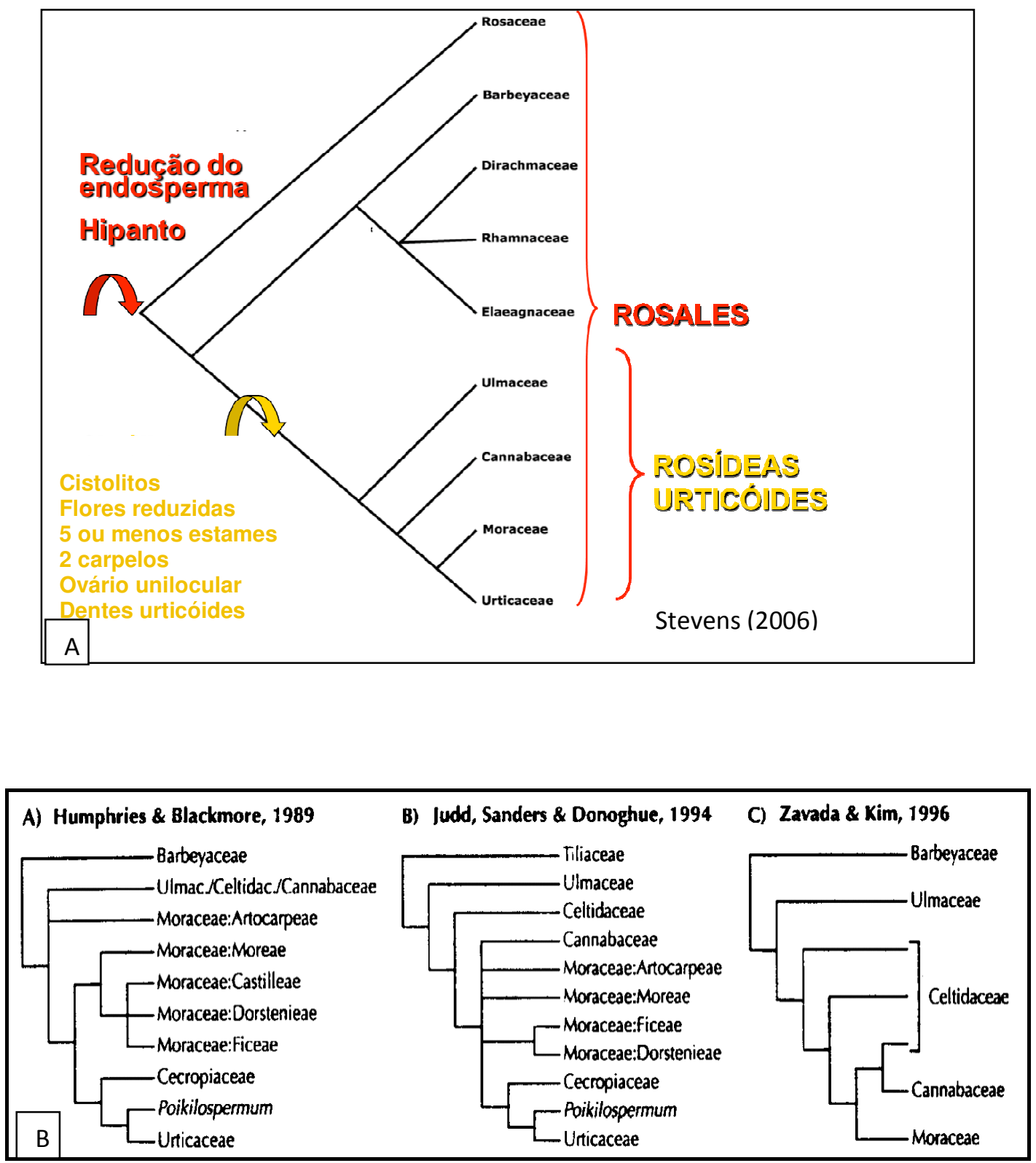

Figura. 2: Posição e relacionamento filogenético das famílias urticóides. A - rosídeas urticóides e suas sinapormorfias (adaptado de Stevens (2001) e Kravtsova \& Oskolski (2007)); B - adaptado de Sytsma et al. (2002). 
Tabela 1: Comparações morfológicas de Cannabaceae, Moraceae e Urticaceae.

\begin{tabular}{|c|c|c|c|}
\hline CARACTERES & URTICACEAE & CANNABACEAE & MORACEAE \\
\hline Estigma & Simples & Simples & Bífido \\
\hline Óvulo & Basal/Ortótropo & Apical/Anátropo & Apical/Anátropo \\
\hline Látex & Apenas na periderme & Ausente & Em toda a planta \\
\hline Hábito & Herbáceo ou com & Herbáceo ou Lenhoso & Lenhoso \\
\hline pouca lenhosidade & & Ausentes \\
\hline Cistólitos Alongados & Presentes & Ausentes & Retos \\
\hline Estames & Elásticos/reflexivos & Retos no botão & . \\
\hline
\end{tabular}

\section{I.2. ESTUDOS NA FLORA DA SERRA DO CIPÓ:}

Uma série de características bióticas e abióticas ocorrentes na Serra do Cipó em Minas Gerais tem despertado o interesse de vários pesquisadores desde a primeira metade do século XIX, como por exemplo, Martius, Pohl e Saint-Hilaire, em expedições ao longo da Cadeia do Espinhaço.

No século $X X$, teve início o desenvolvimento de diversas pesquisas científicas que levaram à elaboração de projetos e à criação do Parque Nacional da Serra do Cipó em 1984. No tocante à flora, foi implantado o projeto "Flora da Serra do Cipó" inicialmente coordenado pelo Prof. Dr. Aylthon Brandão Joly em 1972, visando ao estudo da flora da região. Atualmente, o projeto é coordenado por equipe de botânicos do Instituto de Biociências da Universidade de São Paulo, e tem contado com a colaboração de pesquisadores de várias outras instituições nacionais e internacionais, notadamente da Universidade de Campinas e do Instituto de Botânica de São Paulo.

Giulietti et al. (1987) compilaram a primeira lista de espécies da região, registrando a ocorrência de cerca de 1600 espécies distribuídas em 125 famílias de 
fanerógamas, 10 de pteridófitas e 11 de briófitas. A partir de então se iniciou a publicação de uma série de estudos florísticos detalhados sobre cada família, bem como anatômicos, quimiotaxonômicos, ecológicos e faunísticos, realizados por especialistas ou por alunos de iniciação científica, mestrado e doutorado.

$\mathrm{Na}$ listagem preliminar das espécies realizadas por Giulietti et al. (1987) foram citadas 11 espécies do clado urticóide, sendo Ulmaceae (duas espécies; Carauta, 1987), Moraceae (seis; Carauta, 1987) e Urticaceae (três; Lima \& Godoy, 1987).

$\mathrm{Na}$ continuidade dos estudos florísticos, até o presente, cerca de 70 grupos taxonômicos já foram publicados. Entretanto, as Rosales urticóides permanecem pouco conhecidas na região, resumindo-se à lista de espécies apresentada em 1987. 


\section{OBJETIVOS:}

Tendo em vista realizar o estudo taxonômico e o levantamento das espécies do clado Urticóide e visando contribuir para o projeto "Flora da Serra do Cipó", os principais objetivos do presente trabalho foram:

- Contribuir para o aumento das coleções das famílias desse grupo, por meio da realização de coletas adequadas e da preservação das mesmas como exsicatas e coleções em álcool;

- Apresentar descrições, ilustrações e chaves analíticas de identificação para as espécies ocorrentes na área de estudo;

- Prover análises e comentários sobre a variabilidade morfológica, delimitação taxonômica e distribuição geográfica dessas espécies;

- Verificar a ocorrência e a constância de caracteres citados como importantes para estas famílias em estudo;

- Adquirir experiência em taxonomia dos grupos e prover conhecimento a fim de realização de estudos de revisão e filogenia futuros. 


\section{MATERIAIS E MÉTODOS:}

\section{IIl.1. A ÁREA DE ESTUDO:}

A Serra do Cipó é uma das regiões montanhosas que compõem a Cadeia do Espinhaço, também denominada de Serra Geral. Esta constitui uma das cadeias montanhosas mais importantes do país e é a principal do Planalto Central (King, 1956). Situada entre as latitudes $20^{\circ} 35^{\prime}$ 'S e 11ํ3' W, está limitada ao sul pela região de Ouro Branco, no Estado de Minas Gerais, e ao norte, se estende até a região de Jacobina, no Estado da Bahia, onde é denominada de Chapada Diamantina (figura 3). Sua extensão total é de aproximadamente $1100 \mathrm{~km}$ de comprimento por $50-100 \mathrm{~km}$ de largura, com altitudes entre 800 a 1900-2000 m. A Cadeia do Espinhaço representa o divisor de águas entre os afluentes do Rio São Francisco, a oeste, e os afluentes dos Rios Jequitinhonha e Doce, a leste (Giulietti \& Pirani, 1988; Moreira, 1965; Moreira \& Camelier, 1977).

A Cadeia do Espinhaço se divide em dois setores - o mineiro e o baiano. No setor baiano, as serras recebem diversas denominações regionais como Serra do Tombador, Serra de Senhor do Bonfim, Serra de Jacobina, Serra do Sincorá, Serra da Tromba, Serra de Catolés e Pico das Almas, as quatro últimas situadas na Chapada Diamantina. Na porção mineira, destacam-se localidades como Serra de Ouro Branco, Serra de Ouro Preto, Pico do Itacolomi, Serra do Caraça, Serra da Moeda, Serra da Piedade, Planalto de Diamantina, Serra do Ambrósio, Serra do Cabral, Serra de Itacambira, Serra de Grão-Mogol, Pico do Itambé, Serra de Monte Azul e a Serra do Cipó, entre outras.

A Serra do Cipó situa-se a cerca de $100 \mathrm{~km}$ a norte de Belo Horizonte (figura 4) e abrange parte dos municípios de Congonhas do Norte e Santana do Pirapama ao norte, e Conceição do Mato Dentro, Jaboticatubas e Santana do Riacho ao centro-sul. Localizada entre os limites $19^{\circ} 12^{\prime} 30^{\prime \prime}-19^{0} 30^{\prime} 35^{\prime \prime}$ e e $43^{0} 20^{\prime} 25^{\prime \prime}-43^{\circ} 40^{\prime} 00^{\prime \prime} \mathrm{W}$, a Serra do Cipó é delimitada pelo Rio Cipó, a oeste, e pelos seus afluentes do leste, principalmente o Rio Paraúna (Gontijo, 1993). Esse conjunto orográfico recebe em menor escala vários topônimos locais, como Serra Talhada, Serra Mineira, Morro ou Pico do Breu, Serra Dourada, Serra do Saliteiro, Serra do Palácio, Serra da Farofa, 
Serra da Bandeirinha, Serra da Mutuca e Morro da Pedreira (este um afloramento de calcário localizado na base da serra, ao sul).

No ano de 1984 a porção ao sul da Serra do Cipó, majoritariamente inserida nos municípios de Jaboticatubas e Santana do Riacho, foi transformada em Unidade de Conservação, o Parque Nacional da Serra do Cipó (figura 5), que abrange uma área de $338 \mathrm{~km}^{2}$ (Giulietti et al., 1987).

O relevo da Serra do Cipó constitui um dos "tetos" geomorfológicos do Brasil, alcançando uma das mais elevadas superfícies do Espinhaço, chegando a atingir quase $1700 \mathrm{~m}$ de altitude. O clima da região é denominado mesotérmico brando e semiúmido, com temperaturas médias em torno de $18^{\circ}-20^{\circ} \mathrm{C}$ no verão, e temperaturas médias abaixo de $15^{\circ} \mathrm{C}$ no inverno (Nimer, 1989; Giulietti et al., 1987).

A vegetação na área é composta por um conjunto de comunidades que refletem as variadas condições climáticas e topográficas, predominando as formações campestres. De uma forma geral, nas altitudes acima dos $900 \mathrm{~m}$, encontram-se os campos cerrados de altitude, campos rupestres pedregosos, geralmente com grandes afloramentos rochosos, campos rupestres areno-pedregosos e brejosos (Vitta, 1995; Pirani, 2003). As formações florestais da Serra do Cipó restringem-se às matas ciliares, acompanhando os ambientes úmidos; às florestas estacionais semidecidual, nas encostas suavemente onduladas e florestas estacionais decidual nos afloramentos de calcário da face oeste da Serra do Cipó (Giulietti et al., 1987; Meguro et al., 2007) (figura 6).

Devido à grande extensão da Serra do Cipó, os estudos iniciais do Projeto Flora da Serra do Cipó restringiram-se somente à porção sul, em terrenos situados, especialmente nos municípios de Jaboticatubas e Santana do Riacho, entre os limites $19^{\circ} 20^{\prime}$ 'S e $43^{0} 30^{\prime}-43^{\circ} 40^{\prime} \mathrm{W}$. A partir de 1990 , entretanto, em parte pelas facilidades trazidas com a implantação do Parque Nacional, várias outras áreas passaram a ser visitadas e exploradas em termos botânicos. Essa expansão dos horizontes de coleta ampliou as paisagens amostradas e tem resultado em forte incremento do número de táxons encontrados na Serra. 


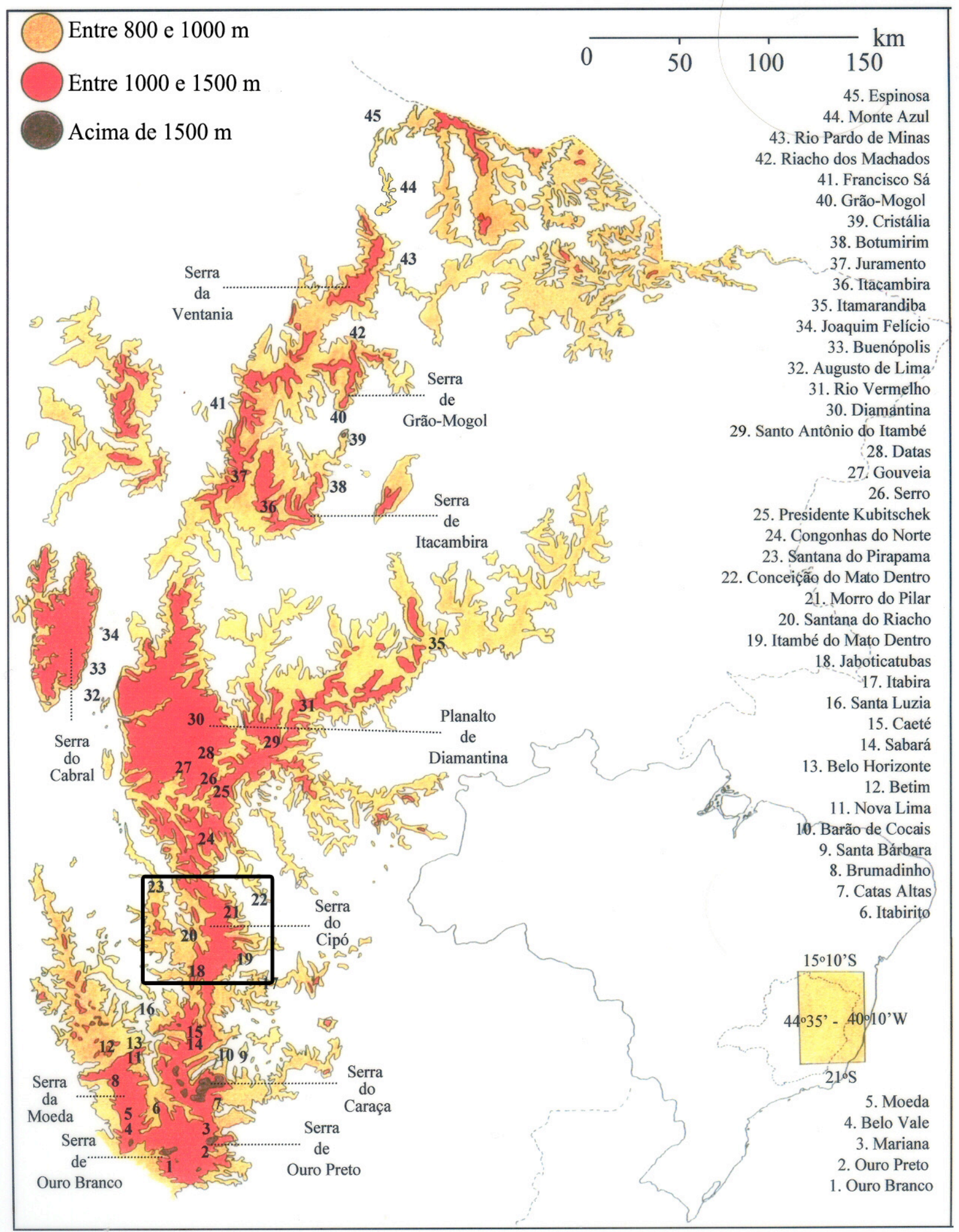

Figura 3. Localização da Cadeia do Espinhaço, com os topônimos principais e destaque para a Serra do Cipó. Minas Gerais. Modificado de Rapini (2000). 

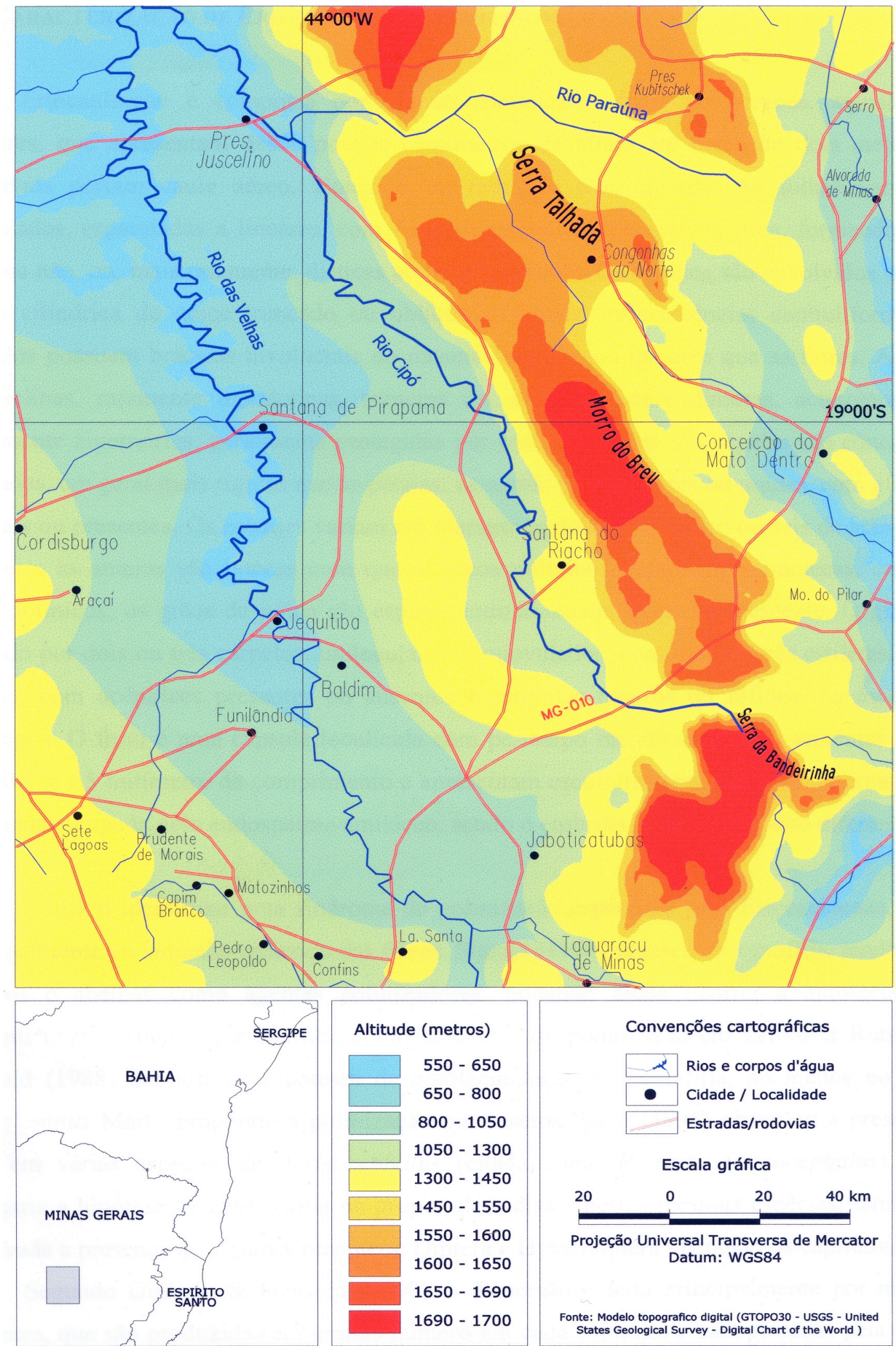

Figura. 4: Região da Serra do Cipó destacando as principais localidades, vias de acesso e as maiores altitudes. Modificado de Costa (2001). 


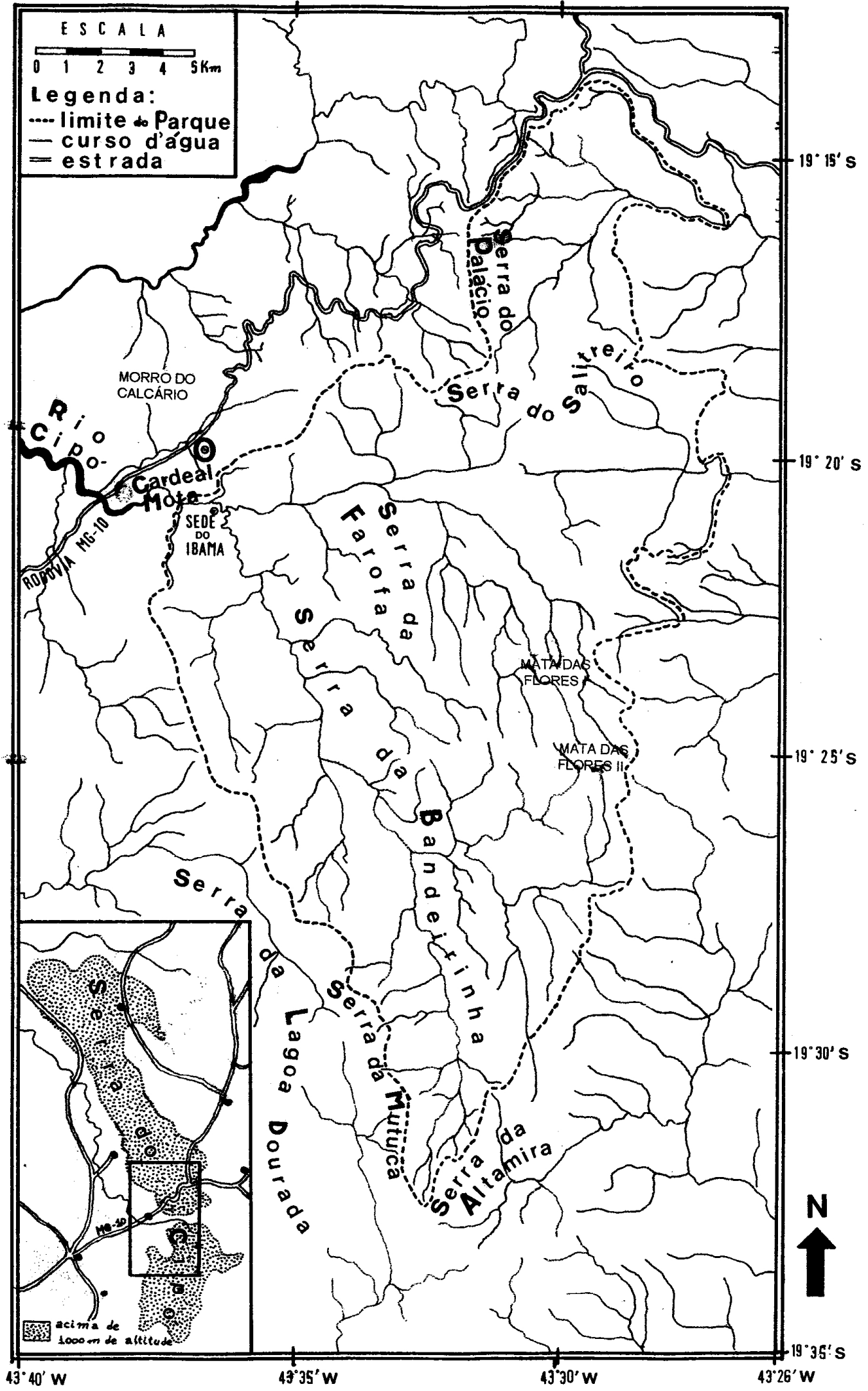

Figura 5: Mapa detalhado do Parque Nacional da Serra do Cipó. Modificado de Gontijo (1993). 

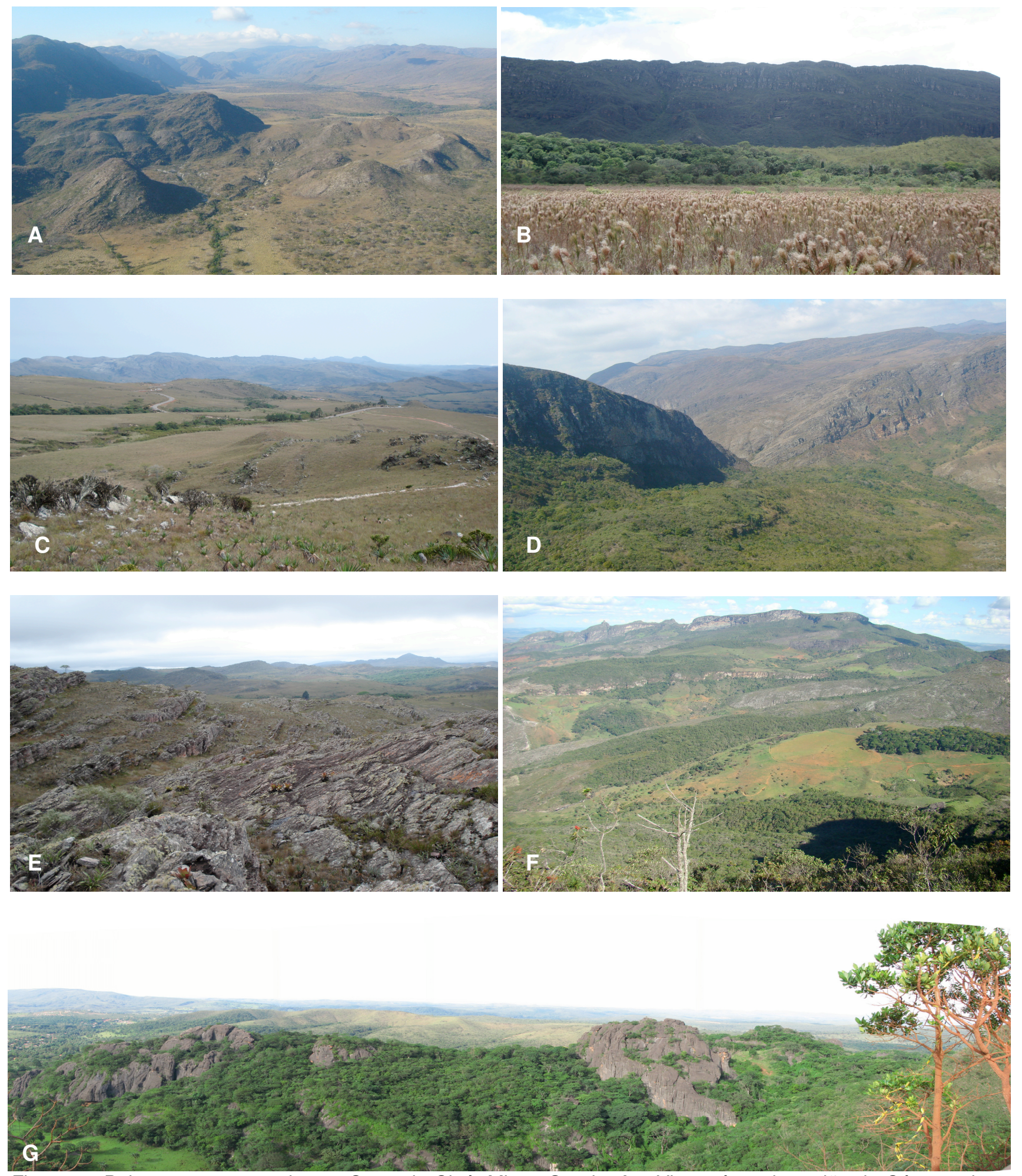

Figura. 6. Paisagens encontradas na Serra do Cipó, Minas Gerais. A - Vista aérea da região do Córrego do Gavião. B - Campo arenoso e capão de mata no vale do Rio Cipó, com a Serra da Bandeirinha ao fundo. C Campo rupestre com a mata ciliar do Córrego Duas Pontinhas ao fundo. D - Mata de encosta próxima ao Alto do Palácio, com afloramentos à esquerda. E - Afloramentos em campo areno-pedregoso na Fazenda Cachoeira da Capivara. F - Fragmentos de Floresta Estacional Semidecidual no distrito de Santana do Rio Preto. G - Vista panorâmica da Floresta Estacional Decidual da APA Morro da Pedreira. Fotos: A - F, E.G.A. Martins. G, M.F. Calió. 


\section{III.2. LEVANTAMENTO DAS ESPÉCIES:}

\section{III.2.1. Levantamento Bibliográfico:}

O levantamento bibliográfico dos trabalhos realizados com o clado das Rosales urticóides (sensu Judd et al., 2002), especialmente nas famílias Ulmaceae, Cannabaceae, Moraceae e Urticaceae s.l., foi feito por meio do "Biological Abstracts", do "Index Kewensis", do "Kew Records of Taxonomic Literature", assim como por meio de referências indiretas constantes na literatura especializada do grupo. Neste levantamento foram incluídos os estudos de taxonomia, levantamento florístico, morfologia, anatomia, distribuição geográfica, fenologia, fitoquímica, entre outros. Foram consultadas algumas obras originais onde as espécies deste grupo (principalmente aquelas mais complexas) foram descritas.

A abreviação dos nomes dos autores foi determinada segundo Brummitt \& Powel (1992) e a das obras princeps, segundo Stafleu \& Cowan (1973-1988). A abreviação dos periódicos seguiu-se a recomendação de Bridson \& Smith (1991).

A terminologia morfológica botânica adotada seguiu as classificações de Bell (1993), Harris \& Harris (1997), Hickey (1973), Font Quer (1989), Radford et al. (1974), Stearn (1980) e Weberling (1989) e para estruturas características do grupo urticóide, utilizaram-se fundamentalmente os trabalhos de Berg (2001) e Mello-Filho et al. (2001).

\section{III.2.2. Coleta e Conservacão do Material:}

Foram realizadas sete viagens de campo com o objetivo de coletar amostras botânicas, observar as espécies do grupo urticóide em seu habitat natural e obter material fotográfico. Essas expedições de coletas tiveram início em julho de $2006 \mathrm{e}$ sendo a última realizada em março de 2008 (tabela 2). Com base nas fichas de exsicatas da "Coleção da Flora da Serra do Cipó - CFSC" depositadas no Herbário do Instituto de Biociências da Universidade de São Paulo (SPF) e no Herbário do Instituto de Botânica (SP) foram selecionadas e visitadas as principais áreas especialmente ricas em táxons do grupo Urticóide. Contudo, foi também realizado um trabalho 
exploratório em áreas ainda pouco ou não-visitadas, como a face leste da Serra do Cipó.

As viagens de coletas foram concentradas principalmente na Serra do Cipó. No entanto, dando continuidade às expedições foram visitadas outras localidades ao longo da Cadeia do Espinhaço com o intuito de aumentar a área amostrada do grupo e permitir uma comparação e verificação da variação morfológica das espécies urticóides.

Tabela 2: Período das expedições de coleta e respectivas localidades visitadas.

\begin{tabular}{|c|c|}
\hline PERIODO & LOCALIDADES VISITADAS \\
\hline Julho de 2006 & $\begin{array}{l}\text { Serra do Cipó (APA Morro da Pedreira e ao longo da Rodovia MG- } \\
\text { 010). }\end{array}$ \\
\hline Setembro de 2006 & $\begin{array}{l}\text { Serra do Cipó (APA Morro da Pedreira e ao longo da Rodovia MG-010, } \\
\text { Pico do Breu e Serra do Palácio), além do Planalto de Diamantina. }\end{array}$ \\
\hline Janeiro de 2007 & $\begin{array}{l}\text { Serra do Cipó (APA Morro da Pedreira, região da Usina Dr. Pacífico } \\
\text { Mascarenhas, porção norte e ao longo da Rodovia MG-010), além do } \\
\text { Planalto de Diamantina. }\end{array}$ \\
\hline Fevereiro de 2007 & $\begin{array}{l}\text { Serra do Cipó (APA Morro da Pedreira, porção norte, trilha da Farofa, } \\
\text { Cânion das Bandeirinhas e ao longo do Ribeirão Mascates. }\end{array}$ \\
\hline Maio de 2007 & $\begin{array}{l}\text { Serra do Cipó (APA Morro da Pedreira, região da Usina Dr. Pacífico } \\
\text { Mascarenhas, Córrego Duas Pontinhas, Três Pontinhas e Alto do } \\
\text { Palácio). }\end{array}$ \\
\hline Agosto de 2007 & $\begin{array}{l}\text { Serra do Cipó (APA Morro da Pedreira, Trilha da Farofa e face leste da } \\
\text { serra, na região de Itambé do Mato Dentro). }\end{array}$ \\
\hline Março de 2008 & Serra do Cipó (ao longo da Rodovia MG-010). \\
\hline
\end{tabular}

Todo o material coletado foi imediatamente prensado no campo, utilizando estufa de campo ou álcool $70^{\circ} \mathrm{GL}$. Posteriormente, em laboratório, o material recebeu tratamento convencional de secagem em estufa elétrica, mantida aproximadamente a 55-60ㅜ $\mathrm{C}$ por 2-4 dias. Uma vez secos, os materiais foram encaminhados para a montagem em papel alcalino próprio para exsicatas, recebendo as etiquetas com os dados referentes à coleta e ao próprio material. As exsicatas foram incluídas na coleção do Herbário SPF, com duplicatas enviadas principalmente aos herbários ESA, SP, R, 
GUA, UEC e BHCB. Flores e frutos foram conservados em solução de álcool etílico $70 \%$ para os estudos e confecção das ilustrações.

No campo foram feitas observações fenológicas, ecológicas e de outros aspectos da biologia das espécies como coloração das flores e frutos, hábito, altura das plantas e habitat que foram, posteriormente, incorporados às descrições, chaves analíticas e comentários.

\section{III.2.3. Consultas aos Herbários e Material Analisado:}

O levantamento das espécies do grupo urticóide ocorrentes na Serra do Cipó foi realizado, inicialmente, a partir do acervo do Herbário do Departamento de Botânica do Instituto de Biociências da Universidade de São Paulo (SPF) e do Herbário do instituto de Botânica do estado de São Paulo (SP). Esses herbários abrigam grande número de materiais provenientes da Serra do Cipó, em coleção denominada de "Coleção da Flora da Serra do Cipó - CFSC", depositado nos herbários SP, SPF e UEC. Adicionalmente, outros herbários com coleções de plantas provenientes da Serra do Cipó e herbários depositários de rico material das famílias urticóides foram consultados através de visitas pessoais ou solicitação de empréstimos, tendo por objetivo o levantamento das espécies já coletadas provenientes da região e analisar as possíveis variações morfológicas existentes para cada táxon. Também foram verificados informações sobre distribuição geográfica e fenologia, além de dados referentes ao habitat das espécies que ocorrem na área de estudo.

$\mathrm{Na}$ citação de "Material Examinado" foram referidos todos os materiais coletados na Serra do Cipó, citados de acordo com o modelo proposto pelo projeto Flora da Serra do Cipó e trabalhos como o de Groppo \& Pirani (2005) e Sano (1998). Nas espécies cujo material oriundo da Serra do Cipó era insuficiente para compilar uma descrição completa, foram examinados materiais provenientes de outras localidades, e isso permitiu também investigar a variação morfológica, assim como auxiliar na compreensão do comportamento fenológico e distribuição geográfica. Nesses casos, tais materiais foram mencionados em "Material Adicional".

Os materiais analisados foram citados e organizados em ordem alfabética de família, gênero e epíteto específico. Na citação dos materiais examinados e adicionais, 
seguiram-se a sequência: estado; município; localidade; coletor; número da coleção a que pertence (no caso das coleções especiais, "Coleção Flora da Serra do Cipó CFSC" e "Coleção Flora dos Campos Rupestres - CFCR"); número de coletor (para os materiais não pertencentes às coleções referidas acima); data; abreviações das estruturas reprodutivas presentes; sigla do herbário no qual está depositado o material, entre parênteses, com respectivo número de tombo para os casos onde não são indicados coletor ou o número da coleção. Quanto aos estados fenológicos e de exsicatas foram utilizadas as seguintes abreviações:

- "fl." = para a presença de flores;

- "fr." = para a presença de frutos;

- "bt." = para a presença de botão floral;

- "st." = para material estéril;

- "s.n." = para material sem número de coletor.

Os herbários consultados estão relacionados abaixo, com acrônimos segundo Holmgreen et al. (1990).

BHCB - Universidade Federal de Minas Gerais;

ESA - Universidade de São Paulo, Escola Superior de Agricultura Luiz de Queiroz;

HRCB - Universidade Estadual Paulista, Rio Claro, SP;

MBM - Museu Botânico Municipal, Curitiba, PR;

OUPR - Universidade Federal de Ouro Preto, MG;

R - Universidade Federal do Rio de Janeiro, Museu Nacional;

RB - Jardim Botânico do Rio de Janeiro;

SP - Instituto de Botânica, São Paulo;

SPF - Universidade de São Paulo, Instituto de Biociências;

UEC - Universidade Estadual de Campinas. 


\section{III.2.4. Análise e Identificação do Material:}

A análise do material foi realizada nas dependências do Laboratório de Sistemática Vegetal do Departamento de Botânica, Instituto de Biociências, Universidade de São Paulo.

$\mathrm{Na}$ análise do material botânico foram estudados todos os materiais herborizados, sendo observado o maior número de caracteres vegetativos e florais, os quais foram anotados em uma tabela para cada espécie.

$\mathrm{Na}$ análise morfológica do material herborizado foram anotadas todas as características quantitativas e qualitativas das estruturas vegetativas e florais. As estruturas de tamanhos reduzidos e delicadas, como as inflorescências, flores, frutos e sementes foram observados com o auxílio de estereomicroscópio Olympus SZH-10. As estruturas reprodutivas, quando secas, foram reidratadas por fervura em água com algumas gotas de glicerina 50\%, durante 0,3 a 2 minutos, para posterior dissecção.

As medições foram realizadas com régua milimetrada e seus valores apresentados nas descrições representam as medidas mínimas e máximas de estruturas maduras analisadas, sendo que as medidas entre parênteses referem-se a valores divergentes da variação comumente encontrada. Características não mensuráveis, como hábito, altura das plantas, indumento e coloração das estruturas, foram tomadas ou em observações de campo ou através das fichas das exsicatas examinadas.

A identificação dos materiais foi realizada até o nível de espécie utilizando-se, para isso, descrições das obras originais, fotografias de materiais-tipo, bibliografia especializada e comparação com os materiais dos herbários visitados. Em virtude das controvérsias existentes sobre os conceitos de espécie, neste trabalho foi adotado o "conceito taxonômico de espécie", tendo em vista as discussões e restrições reportadas recentemente por autores como Sites \& Marshll (2004), Rapini (2004) e Henderson (2005). 


\section{III.2.5. Apresentação das Espécies:}

As espécies foram apresentadas em ordem alfabética de gênero e de epíteto específico, por questões de praticidade e pela complexidade acerca das informações sobre a proximidade filogenética das urticóides.

As descrições das famílias e dos gêneros ocorrentes na Serra do Cipó foram realizadas com base na literatura consultada e no material herborizado. As descrições das espécies foram obtidas, principalmente, dos materiais provenientes de coletas realizadas na área e, quando necessário, complementado com material adicional de outras áreas.

A partir dos dados provenientes das descrições foram confeccionadas chaves de identificações dos gêneros e espécies. A elaboração das chaves analíticas de identificação foi baseada nos materiais examinados, com apoio da literatura especializada. Para a elaboração dessas chaves procurou-se priorizar o uso de caracteres morfológicos vegetativos, complementados por caracteres florais quando necessário. Adicionalmente foram utilizados dados referentes ao hábito das plantas como informações complementares.

Para cada espécie apresentada foram realizados breves comentários sobre o histórico taxonômico, problemas de circunscrição específica, variabilidade morfológica, caracteres diagnósticos, dispersão e polinização, características ecológicas e, quando possível, o significado do epíteto específico, compilado de literatura específica sobre as espécies e a partir de dicionários tais como o de Faria (1967), Font Quer (1989) e Stearn (1980).

Comentários sobre a distribuição geográfica das espécies foram realizados a partir de literatura especializada e do material examinado referente às coletas efetuadas na área de estudo e em outras localidades.

As informações sobre a fenologia representam os prováveis períodos de floração e frutificação das espécies, os quais foram obtidos a partir das datas de coletas e das fichas das exsicatas examinadas. 


\section{III.2.6. Figuras:}

Os mapas gerais da localização da Cadeia do Espinhaço, da Serra do Cipó e do Parque Nacional foram extraídos e modificados a partir dos trabalhos de Giulietti \& Pirani (1988), Gontijo (1993), Costa (2001) e Rapini (2000).

As fotografias de fisionomias e das espécies foram obtidas por meio do uso de câmera digital Sony e executados pelo autor do presente trabalho ou por pesquisadores colaboradores presentes ao longo das expedições realizadas.

\section{III.2.7. Ilustracões:}

Foram confeccionadas pranchas de ilustração para cada espécie, abrangendo, sobretudo, os detalhes diagnósticos de cada uma delas e/ou do gênero e família. Os hábitos foram ilustrados utilizando exsicatas como modelos, associados literatura especializada e à fotografias de plantas na natureza, quando obtidas. Os detalhes de flor, fruto, entre outros, foram observados e ilustrados sob estereomicroscópio. Todas as ilustrações foram cobertas a nanquim sobre papel vegetal. 


\section{TRATAMENTO TAXONÔMICO:}

\section{IV.1. CANNABACEAE Martynov}

Ervas, anuais ou perenes, arbustos ou árvores, escandentes ou não, destituídos de látex, ocasionalmente espinescentes. Folhas alternas ou raramente opostas, geralmente dísticas, simples ou compostas, pecioladas, base em geral oblíqua, margem inteira ou serreada; venação actinódroma, raro camptódroma a semicraspedódroma; estípulas intrapeciolares, raramente interpeciolares, livres ou fundidas, decíduas. Inflorescências axilares, cimeiras ou racemos fasciculados a raro paniculados, geralmente flores pistiladas solitárias e axilares. Flores não vistosas, bissexuadas ou unissexuadas (plantas monóicas, dióicas ou polígamas), actinomorfas ou zigomorfas, monoclamídeas; perianto subcampanulado, tépalas (2-)4-8(-9), prefloração imbricada, livres ou unidas na base, persistentes; flor estaminada: estames em número igual ou menor que as tépalas, raramente o dobro, oposititépalos, filetes livres ou soldados ao tubo do perianto; anteras bitecas, rimosas, dorsifixas, geralmente pouco versáteis; pistilódio geralmente presente; flor pistilada: ovário súpero, (1-)2-carpelar, séssil ou estipitado, 1(-2)-locular; óvulo 1, placentação apical, pêndulo, anátropo; estiletes 2, simples ou bifurcados, geralmente persistentes no fruto; estigmas decorrentes; estaminódios presente ou não. Fruto drupa ou sâmara, raramente aquênio; semente com embrião reto ou curvo, endosperma abundante a ausente.

Cannabaceae apresenta 11 gêneros e cerca de 170 espécies, configurando uma distribuição cosmopolita, exceto no Ártico, sendo que a distribuição de Humulus lupulus L. na Ásia ainda é incerta (Sattarian, 2006). Segundo Mabberley (1997), dois gêneros incluídos nessa família "causam grande felicidade e infelicidade ao Homem": Cannabis L., gênero monotípico (C. sativa L.) do qual se extrai a maconha e o haxixe, e Humulus L., gênero ao qual pertence o lúpulo ( $H$. lupulus L.), um dos componentes utilizados na fabricação da cerveja. Celtis L. é o gênero com maior número de espécies da família, distribuindo-se pela Ásia, África e pelo continente americano. No Brasil, encontram-se 4 gêneros: Celtis L. e Trema Lour. (nativos) e Cannabis L. e Humulus L. (introduzidos) e aproximadamente 15 espécies (Souza \& Lorenzi, 2008), habitando em diferentes 
biomas. Espécies arbóreas desses gêneros são encontradas em florestas úmidas do Norte e outras em florestas semidecidual e decidual do nordeste e sudeste.

A circunscrição de Cannabaceae tem sido bastante controvertida. Tradicionalmente seus gêneros eram incluídos em Moraceae ou Urticaceae, ou sua delimitação confundia-se com o complexo Ulmaceae-Celtidaceae-Cannabaceae. Porém, os acúmulo de estudos recentes em ultra-estrutura, número de cromossomos e sítios de restrição do cpDNA (Wiegref et al., 1998), dados matk (Song et al., 2002) e com seqüências de rbcL, trnL-F, ndhF e dados moforlógicos (Sytsma et al., 2002, Sattarian, 2006; Kravtsova \& Oskolski, 2007) vem contribuindo para a delimitação de um grupo monofilético bem corroborado. Assim, a circunscrição tradicional de Cannabaceae foi profundamente ampliada com os recentes estudos em filogenia, tendo sido incluídos na família os gêneros Celtis e Trema, tradicionalmente reconhecidos como membros de Ulmaceae subfamília Celtidoideae (e.g. Engler, 1907; Cronquist, 1981, 1988; Sweitzer, 1971).

Os representantes de Cannabaceae compartilham várias semelhanças com os de Moraceae e Urticaceae, diferindo deles pela ausência de látex e pelas bases foliares assimétricas. De Urticaceae diferem ainda pelo ovário bicarpelar e 2 estiletes. Quanto aos gêneros que permanecem ainda em Ulmaceae, distingue-se de Cannabaceae pelo padrão de nervação foliar, anatomia, pela morfologia floral, tipo de fruto e a forma do embrião e do pólen (Sytsma et al., 2002; Kravtsova \& Oskolski, 2007).

Caracteristicamente, os membros de Cannabaceae podem ser reconhecidos facilmente pela presença de folhas serreadas, com nervação actinódroma, estípulas intrapeciolares e botões profilares proeminentes. Apresentam polinização anemófila, assim como as Urticaceae, e seus frutos são provavelmente dispersados por uma grande variedade de animais. 


\section{Chaves para os gêneros presentes na Serra do Cipó}

1. Árvore ou arbusto escandente, espinescente; flores estaminadas e bissexuadas; estigmas 2, bifurcados

1. Celtis

1'. Árvore inerme; flores estaminadas, pistiladas e bissexuadas (estas raras); estigmas 2, simples

2. Trema

\section{Celtis L.}

Árvore, arbusto ou escandente, monóica ou polígamo-monóica; ramos espinescentes, raro inermes, espinhos retos ou curvos, solitários ou geminados, simples ou ramificados, às vezes com braquiblastos. Folhas alternas, membranáceas a coriáceas, margem inteira a serreada, base atenuada a cordada, geralmente oblíqua; venação actinódroma; pontuações na lâmina devido a presença de cistólitos; estípulas intrapeciolares, livres. Inflorescência cimeira axilar, apresentando-se em 3 modos: a) apenas com 1-(2-3) flores bissexuadas (às vezes, funcionalmente pistiladas); ou b) com 2 flores bissexuadas (funcionalmente pistiladas) e poucas a numerosas flores estaminadas; ou c) somente com poucas a numerosas flores estaminadas; brácteas diminutas, decíduas. Flores bissexuadas ovóides; flores estaminadas globosas, pistilódio presente; pedicelo curto; receptáculo viloso internamente e externamente; tépalas (4)5, unidas na base, imbricadas no botão floral, margem ciliada; androceu isostêmone, estames funcionais nas flores bissexuadas, decíduos; ovário séssil, 1locular; estiletes 2, simples, lobados ou bifurcados, reflexos, superfície interna estigmática. Fruto drupa pouco carnosa, subglobosa, endocarpo lenhoso, estilete persistente; semente subglobosa a globosa; embrião curvo, cotilédones largos, conduplicados ou raramente aplanados.

Gênero com 70-100 espécies, distribuídas nas regiões tropicais e temperadas dos dois hemisférios, das quais 50 ocorrem na América do Sul e uma na Serra do Cipó, habitando em orla e no interior de matas e, em capões de matas.

Em escala regional, Celtis tem sido monografado para a Malásia por Soepadmo (1977), China por Shu (2003), na África tropical por Letouzey (1972), para todo o continente africano por Sattarian \& van der Maesen (2005) e para a América do Sul por 
Berg \& Dahlberg (2001). Nesses trabalhos sobre Celtis tem sido frequente a delimitação de grupos ecológicos de espécies, incluindo o estudo das espécies encontradas no Brasil.

Soepadmo (1977), por exemplo, em estudo sobre as espécies de Celtis malasianas, identificou a preferência ambiental de dois grupos ecológicos. Destes, um grupo (Celtis tetranda Roxb., C. rubrovenia Elmer, C. timorensis Span. e C. philippensis Blanco) germinam fortemente em substratos rochosos e em afloramentos calcários, assim como os espécimes de Celtis ocorrentes na Serra do Cipó. Em conformidade com esta preferência ambiental, esse grupo demonstra hábito de crescimento rápido e amplo, ocorrendo principalmente em florestas semidecidual.

$\mathrm{Na}$ América do Sul, dois grupos de espécies podem ser reconhecidos, um incluindo Celtis ehrenbergiana (Klotzsch) Liebm. e C. chichape (Wedd.) Miq., e o outro incluindo C. brasiliensis (Gardner) Planch. e C. orthacanthos Planch., ao qual pertence C. iguanaea (Jacq.) Sarg. Este segundo grupo ocorre principalmente no Sul da América do Sul, sendo a maior parte destes habitando florestas secas (Elias, 1970). As principais diferenças entre os grupos na América do Sul são a presença de espinhos e a distribuição geográfica. As espécies de Celtis da África são morfologicamente relacionadas com as de Celtis da Ásia por compartilhamento de características de suas folhas, sementes, embrião e ausência de espinhos. Celtis sul-americanas estão caracterizadas principalmente pela presença de espinhos, domácia foliar e estigmas bifurcados ou 2-lobados (Berg \& Dahlberg, 2001).

Entretanto, vários táxons são muito difíceis de serem separados e diversos autores tem destacado a dificuldade em delimitá-los (Elias, 1970; Hunziker \& Dottori, 1976; Romanczuk \& Martinez, 1978; Nee, 1984; Berg \& Dahlberg, 2001; Torres \& Luca, 2005). A maior dificuldade na taxonomia de Celtis tem sido encontrar bons caracteres morfológicos para distinguir as espécies. Atualmente, mais de 500 binômios estão listados no International Plant Names Index (IPNI, 2008), aparentemente o mais recente banco de dados para Celtis em todo o mundo, tornando óbvia a complicada situação taxonômica do gênero. Por exemplo, Miquel (1853) reconheceu 30 espécies e Planchon (1873) 19 espécies e cinco variedades para a região Neotropical. Para a América do Sul, Baehni (1936) reduziu o número para nove espécies e, mais recentemente, Berg \& Dahlberg (2001) aceitaram apenas seis em sua revisão. Torres \& Luca (2005) e 
Sattarian (2006) ponderaram que a falta de uma monografia geral para o mundo levou a que os conceitos de espécies variassem consideravelmente nas floras regionais, e defenderam as recentes tendências ao reconhecimento de um número menor de espécies, aceitando-se nessas, maior amplitude morfológica. Essa abordagem argumenta a necessidade e permite o aprofundamento dos estudos sistemáticos entre as espécies de Celtis, especialmente filogenéticos e biogeográficos.

Morfologicamente, o gênero Celtis L., está próximo do gênero Trema Lour., diferenciando-se deste por possuir espinhos e pistilódio geralmente pouco desenvolvido e piloso. Na Flora da Serra do Cipó, dentre as várias características morfológicas analisadas nos táxons estudados, observou-se que os tricomas das folhas, os ramos, os espinhos, o tamanho dos frutos e a presença de domácias como os principais caracteres diagnósticos para a delimitação aqui proposta.

1.1. Celtis iguanaea (Jacq.) Sarg., The Silva of North America 7: 64. 1895.

Nome vernacular: grapiá (Rocha et al., 2000); crindiúva (Carauta, 1996); grãode-galo (SP, Crestana et al., 2006); joá-merim, jameri (Lorenzi, 2002); gumbixava, cipóespinho (Torres \& Luca, 2005); mutamba (MG, Lopes \& Andrade s.n. BHCB 9128).

Figura 7: A - E.

Árvore, arvoreta ou arbusto escandente até $6 \mathrm{~m}$ alt; ramos sulcados ou não; tomentosos a vilosos na porção distal, tornando-se pubescentes a glabros. Folhas: pecíolo 3,5-14,3 $\mathrm{mm}$ compr., levemente sulcado, às vezes canaliculado, tomentoso a viloso, glabrescente; estípulas 2,5-4,8 $\mathrm{mm}$ compr., pubescentes a glabras, raro estrigosas, decíduas; lâmina 2,6-9,2 cm compr., 2,4-5,5 cm larg., membranácea a cartácea, amplamente elíptica a oval-elíptica, ápice agudo a acuminado, às vezes macronulado, base arredondada a subcordada, raramente oblíqua, margem serreada a partir do terço médio inferior ou da metade; face adaxial esparso-estrigosa, mais densamente sobre as nervuras mediana e secundárias e nas domácias; face abaxial amarelo-vilosa, macia ao toque, mais densamente ao longo das nervuras, às vezes, esparso-estrigosa; venação impressa na face adaxial e proeminente na abaxial; domácias marsupiformes, glabras ou barbeladas, dispersas por toda a lâmina, às vezes, conspícuas na base da folha ou evidentes apenas nas folhas jovens. Flores 
estaminadas até $4 \mathrm{~mm}$ diâm.; tépalas tomentosas externamente, ca. 1,1 mm compr.; estames ca. 0,8 mm compr., dorsifixos, anteras rimosas, ca. 0,4 mm compr. Flores bissexuadas, isoladas ou em pares, 2,5-5,5 mm compr., 1,1-2,3 mm larg.; pedicelo 2,54,3 mm compr., levemente viloso a glabrescente; sépalas vilosas em ambas as faces, raro estrigosas a glabras externamente, 1,3-2,1 mm compr.; estames 1,9-2,1 mm compr., dorsifixos, anteras rimosas, 0,5-0,7 mm compr.; ovário esparso-estrigoso. Drupa ovóide, esparsamente estrigosa, densamente vilosa na base, marrom-escuro ou alaranjado, 4,7-8,1 mm compr., 4,7-5,5 mm diâm.; semente ovóide a globosa, 3,8-7,5 mm compr., 3,6-6,5 mm diâm.

Material examinado: Minas Gerais, Santana do Riacho, ao longo da rodovia Belo Horizonte - Conceição do Mato Dentro: $\mathrm{km}$ 101, em mata mesófila, J.R. Pirani et al. CFSC 6691, 6.XI.1980, fl., fr. (SP, SPF); Cardeal Mota, APA Morro da Pedreira (blocos do Grupo II), nos afloramentos próximos à Fazenda Canto da Serra, J.R. Pirani et al. CFSC 13290, 22.XI.1993, fr. (SPF); ao longo da rodovia MG-010, logo após a ponte sobre o Rio Cipó (área do antigo Posto de Gasolina), E.G.A. Martins et al. 56, 17.I.2007, fr. (SPF); APA Morro da Pedreira,

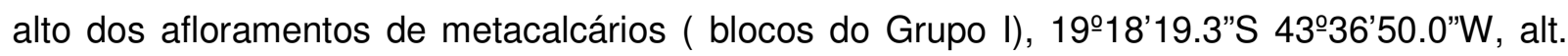
920 m, E.G.A. Martins et al. 52, 17.I.2007, fr. (SPF); estrada de acesso à Usina Coronel Américo Teixeira - UCAT, M.A. Lopes \& P.M. Andrade s.n., 24.II.1985, fr., fl. (BHCB 9128); estrada em direção ao município Santana do Riacho e de acesso à APA Morro da Pedreira, E.G.A. Martins et al. 92, 15.II.2007, fr. (SPF); arredores do lago da Usina Hidrelétrica Coronel Américo Teixeira - UCAT, P.M. Andrade \& M.A. Lopes s.n., 14.IV.1985, fr. (BHCB 17543, ESA); P.M. Andrade \& M.A. Lopes s.n., 14.IV.1985, fr. (BHCB 10055).

Material adicional: Minas Gerais, Barroso, Mata do Baú, L.C.S. Assis 339, 20.X.2001, fl., fr. (CESJ, SPF); Lagoa Santa e Matozinhos, na APA Carste de Lagoa Santa, A.E. Brina \& L.V. Costa s.n., 2.IIl.1996, fr. (BHCB 36585); Patrocínio, Serra do Salitre, a oeste da Lagoa Campestre, em região dos carbonatitos, G. Ceccantini 277, 24.III.1994, bt. (ESA, SPF). São Paulo, Campinas, Parque Jambeiro, P.R.P. Andrade \& R.M. Chagas 1187, 19.Il.1995, fr, fl. (IAC, SPF); Monte Alegre do Sul, Fazenda Benati, L.C. Bernacci et al. 1361, 17.III.1995, fr. (IAC, SPF); São José do Rio Preto, J.Y. Tamashiro et al. 210, 27.VI.1994, fr. (SP, SPF, UEC); Luiz Antonio, Várzea do Jenipapo - VCP, área de inundação próximo a fábrica, S.A. Nicolau \& V.B. Faria 1908, 7.X.1999, fl.fr. (SP, SPF). 
Celtis iguanaea (Jacq.) Sarg. possui ampla distribuição geográfica, ocorre dos Estados Unidos à América do Sul, tropical e subtropical, habitando tanto fisionomias abertas de cerrados e capoeiras, como mata mesófila semidecidual, cerradão, capões de mata, na orla ou nos sub-bosques das matas, e margens de cursos d'água. No Brasil é citada para os estados do Acre, Alagoas, Bahia, Ceará, Espírito Santo, Goiás, Mato Grosso, Mato Grosso do Sul, Minas Gerais, Paraíba, Pará, Paraná, Pernambuco, Rio Grande do Sul, Rondônia, Roraima, Rio de Janeiro, São Paulo e Santa Catarina (Carauta, 1974; Berg \& Dahlberg, 2001). Na Serra do Cipó, ocorre em capões de mata, na orla ou interior de florestas decidual associadas a afloramentos de calcários, sendo muito comum na Área de Proteção Ambiental Morro da Pedreira, um complexo orográfico constituído por afloramentos de calcário, onde antigamente sediava uma mineradora, e nas mediações da Usina Coronel Américo Teixeira - UCAT, a qual fornece o abastecimento energético ao seu grupo controlador - o Grupo VDL, ambiente este caracterizado por solo calcário e areno-pedregoso. A preferência da espécie por substratos carbonáticos já foram constatadas por outros autores, como Carauta et al. (1996) e Rocha et al. (2000), este último considerando-a como boa indicadora da presença de calcário no solo. Em estudo sobre as florestas estacionais decidual a oeste da Cadeia do Espinhaço, Meguro et al. (2007) identificaram C. iguanaea em quatro áreas de afloramentos calcários.

Entretanto, C. iguanaea constitui um complexo que exibe grande variação morfológica ao longo de sua ampla distribuição geográfica, o que tem contribuído para as diversas controvérsias sobre a sua circunscrição (e.g. van Velzen et al., 2006; Berg \& Dahlberg, 2001). Torres \& Luca (2005) no tratamento taxonômico de Ulmaceae para a Flora Fanerogâmica do Estado de São Paulo consideraram C. iguanaea, C. pubescens (Kunth) Spreng. e C. spinosa Spreng. como espécies distintas, diferenciando-as por aspectos morfológicos e morfométricos da forma e base da lâmina foliar, dos tricomas, do pecíolo, das tépalas e do tamanho dos frutos. Da mesma forma, Marchioretto (1988) distinguiu essas três espécies no Rio Grande do Sul, levando em consideração aspectos como o ápice da folha, os tricomas presentes na lâmina e no fruto, e o grau de desenvolvimento do ovário. No entanto, no presente trabalho adota-se a circunscrição proposta na revisão de Celtis feita por Berg \& Dahlberg (2001), por se entender que os caracteres utilizados para distinguir as espécies sinonimizadas por 
estes autores sob $C$. iguanaea são pouco consistentes, já que geralmente se sobrepõem quando da avaliação de materiais analisados diversos, como se pôde constatar aqui. Berg \& Dahlberg (2001) comentam a fragilidade desses caracteres na taxonomia do complexo, devido à sua evidente variação gradativa, destacando o grau de deciduidade dos tricomas e identificando não só dois padrões morfológicos extremos, como uma série de estados intermediários.

O epíteto iguanaea diz respeito ao fato dos frutos serem apreciados por lagartos iguana. Este epíteto foi inicialmente atribuído a Rhamnus iguanaeus por Jacquin (1760), espécie depois transferida para Ziziphus Miller por Lamarck (1789), sendo as primeiras denominações para $C$. iguanaea. Essa confusão histórica com representantes da família Rhamnaceae deve-se a semelhanças na forma e venação foliar, no aspecto geral dos frutos e na presença de espinhos.

Até hoje, materiais de Celtis subg. Mertensia podem ainda ser encontrados em meio a coleções de Ziziphus (Rhamnaceae), e vice-versa. Porém, em termos vegetativos, Celtis diferem destas pelos estômatos (em geral no lado adaxial), pelos numerosos cristais e pelos feixes vasculares no pecíolo em forma de lua crescente e não em U, como em Ziziphus (Rocha et al., 2000).

A biologia floral de C. iguanaea foi descrita em detalhe por Vaz de Arruda \& Sazima (1988), que documentaram a predominância de anemofilia, mas com visitas frequentes por besouros. Os filetes das flores estaminadas são inflexos no botão e na antese são distendidos em um movimento rápido, lançando o pólen, assim como ocorre em C. laevigata Willd (Cuéllar, 1967).

Na maioria das espécies de Celtis, dentre estas $C$. iguanaea, o fruto mantém um rudimento do estilete e o pericarpo apresenta-se constituído por parte carnosa pouco espessada. Entretanto, o pireno, de consistência óssea, unilocular, tem uma única semente, o que a diferencia das espécies do gênero Trema, no qual o pireno tem um lóculo fértil e outro reduzido, estéril (Barroso et al., 1999). A semente madura pode ter endosperma escasso ou ser desprovida dele e seu embrião geralmente é curvo e um dos cotilédones é dobrado e envolvido pelo outro, que são lisos ou ambos plicados.

São citadas propriedades medicinais de sua casca que, cozida, é usada em injeções no tratamento de leucorréias, e seu fruto macerado e fervido é utilizado em casos de disenteria e catarro intestinal. Lofgren (1917) observou que de representantes 
de $C$. iguanaea extrai-se um azeite, embora seu principal emprego seja o da madeira, própria para escultura e obras que requerem elasticidade, além de fornecer um ótimo carvão para pólvora.

Na Serra do Cipó, a espécie foi coletada com flores de outubro a dezembro e frutificando de novembro a março.

\section{Trema Lour.}

Árvores ou arbustos eretos, monóicos ou polígamo-monóicos, ramos inermes. Folhas alternas, geralmente dísticas, simples, margem denticulada a serreada, levemente simétricas, pecioladas, venação actinódroma; estípulas 2, intrapeciolares, livres, decíduas. Inflorescências subsésseis, em fascículos ou cimeiras, as flores estaminadas em cimeiras, as pistiladas ou bissexuadas axilares, isoladas ou aos pares; receptáculo viloso; tépalas (4-)5, curvadas, unidas na base, induplicado-valvares ou \pm imbricadas; flores estaminadas ou bissexuadas: globosas, estames (4-)5, opostos aos lobos do cálice, pistilódio bem desenvolvido; flores pistiladas: ovadas, (4-)5-lobadas, ovário séssil, 1-locular, estiletes 2, superfície interna estigmática; estaminódios ausentes. Fruto drupa pequena, ovóide ou subglobosa, perianto persistente; semente com embrião curvo, cotilédones delgados, endosperma abundante ou escasso.

O gênero Trema ocorre nas regiões tropicais e subtropicais dos dois hemisférios e nas Américas ocorrem de quatro a cinco espécies, desde o sul da Flórida e ilhas do Caribe até o norte da Argentina (Sattarian, 2006). No Brasil ocorre provavelmente uma única espécie, Trema micrantha (L.) Blume, o que leva a alguns autores a acharem que o número de táxons seja provavelmente superestimado devido à dificuldade de delimitação das espécies já propostas, que em geral são plantas pioneiras com ampla distribuição geográfica e grande variabilidade fenotípica (Torres \& Luca, 2005).

O gênero Trema foi inicialmente descrito por Loureiro na Flora Cochinchinensis (1750). Planchon (1873) citou 27 espécies no mundo e Miquel (1853) tratou duas espécies no Brasil. Em estudos mais recentes com Trema, Soepadmo (1977) reconheceu 10-15 espécies, enquanto Todzia (1989), 10-55. 
2.1. Trema micrantha (L.) Blume, Mus. Bot. 2: 58. 1856.

Nome vernacular: candiúva, canduirea, coatindiba (MG e BA, Carauta, 1974), coatinduva, candeúva, crandiúva (RJ, Rocha et al., 2000); crindiúva, pau-pólvora, candiúba, pindaúva-vermelha (SP, Crestana et al., 2006); gurindiva, lixa, mutamba, polveiro, Quindiúba ( MG, M.A. Lopes 765)

Figura 7: F - J.

Árvore, arvoreta ou subarbusto, 3-6 m alt.; caule verrucoso, levemente sulcado ou canaliculado, cicatriz das folhas e dos ramos conspícuas, extremidade dos ramos vilosos, flexuosos. Folhas: pecíolo 5,0-11,5 mm compr., levemente sulcado, viloso; estípulas 2,0-5,6 mm compr., lanceoladas, vilosas externamente; lâmina 4,3-10,3 cm compr., 2,1-5,7 cm larg., membranácea ou cartácea, lanceolada, ovada ou oblongolanceolada, às vezes falcada, ápice longo-acuminado, base oblíqua, truncada assimétrica, às vezes subcordada, margem crenulada ou serreada; face adaxial áspera ao toque, esparsamente estrigosa a escabra, esparsamente híspida ao longo das nervuras, venação impressa; face abaxial vilosa a glabrescente, escabra ou macia ao toque, nervuras principal e secundárias proeminentes, venação actinódroma; domácias inconspícuas ou ausentes. Cimeira multiflora; flores sésseis, bracteoladas, creme; flores estaminadas congestas, pistiladas laxas; bractéolas 1,3-1,6 mm compr., lanceoladas, escariosas, marrom-avermelhadas. Sépalas 1,7-3,1 mm compr., 0,7-0,9 mm larg., elípticas a lanceoladas, revolutas, vilosas a levemente tomentosas externamente, verde-amareladas a esverdeadas; flores estaminadas: 1,2-1,7 $\mathrm{mm}$ compr., 5-meras, globosas; estames 5, filetes 0,9-1,9 mm compr., curvos no botão, retos após a antese; anteras 0,7-1,0 mm compr., brancas, rimosas, deiscência explosiva; pistilódio oblongo a cilíndrico, colunar, 1,0-1,5 mm compr., 0,5-0,8 mm larg., base vilosa; flor pistilada: 1,2$4,0 \mathrm{~mm}$ compr., oval, creme-esverdeada, perianto semelhante aos das flores estaminadas; ovário 0,8-2,5 mm compr., ovóide, esverdeado; estiletes 0,7-1,2 mm compr., bífidos, marrom-claros, fundidos na base, persistentes no fruto; flor bissexuada rara, óvulo em geral abortivo. Drupa globosa, 3,5-4,5 mm compr., 2,1-3,2 mm larg., alaranjada a verde-escuro ou vermelha quando madura; semente globosa, 2,0-2,3 mm compr., 1,8-2,3 mm larg., rugosa, enrijecida, marrom-acizentada. 
Material examinado: Minas Gerais, Cardeal Mota, Serra do Cipó, APA Morro da Pedreira (blocos do Grupo I), no alto dos afloramentos de metacalcário, 91'19.3”S 43ํ36’50.0”W, alt. 920 m, E.G.A. Martins et al. 55, 17.I.2007, fl., fr. (SPF); Parque Nacional da Serra do Cipó, 10 km sul da Serra do Cipó, W.R. Anderson et al. 36289, 19.II.1972, fl., fr. (NY, RB); estrada de acesso à APA Morro da Pedreira, E.G.A. Martins et al. 93, 17.Il.2007, fl., fr. (SPF); Santana do Riacho, ao longo da rodovia belo Horizonte - Conceição do Mato Dentro: km 133, M.C. Amaral et al. CFSC 7126, 2.III.1981, fl. fr. (SP, SPF); M.C. Amaral et al. CFSC 7127, 2.III.1981, fl., fr. (SP, SPF).

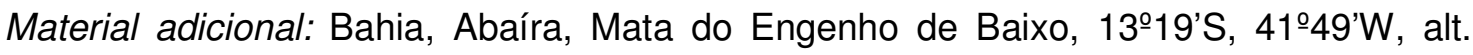
1200 m, W. Ganev 1765, 2.I.1993, fl., fr. (SPF); Montes Claros, rodovia 262, em direção para Aracatu, Alt. 700 m, R.M. Harley et al. CFCR 6739, 12.XIl.1984, fl. (SPF). Espírito Santo, Guarapari, rodovia 060, entre a Praia de Sepetiba e a Praia do Morro do Guarapari, 2037'S 4028'W, W.W. Thomas et al. 6134, 24.Il.1988, fl., fr. (ESA, SPF). Minas Gerais, Caratinga, Fazenda Macedônia/Cenibra - Ipaba, na trilha da Baixada do Coqueiral, P.I.S. Braga \& J.R. Stehmann s.n., 1.XI.1991, fl., fr. (BHCB 19322); Estação Biológica de Caratinga, Mata do Jaó, M.A. Lopes 765, 26.X.1985, fl., fr. (BHCB); Dionísio, Lagoa Jacaré, 1949'15”S, 42³948”W, Alt. 276 m, G.S. França 363, 6.VI.2003, fr. (BHCB, SPF); Grão-Mogol, Vale do Rio Itacambiruçu, 1636'S 4255'W, Alt. 1650 m, J.R. Pirani et al. CFCR 12582, 12.XII.1989, fl., fr. (SPF). São Paulo, São Paulo, Parque Santos Dias, Clareira dos Brinquedos, 2339'47"S 4646'21'W, R.J.F. Garcia 116, 21.VII.1992, fl., fr. (ESA, SPF).

Amplamente distribuída na região Neotropical e no Brasil, T. micrantha (L.) Blume é frequente nos estados do Amapá, Bahia, Ceará, Distrito Federal, Espírito Santo, Goiás, Mato Grosso, Minas Gerais, Pará, Piauí, Rio de Janeiro, Santa Catarina, São Paulo e Rio grande do Sul (Carauta, 1974). Habita frequentemente comunidades vegetacionais em estágios sucessionais iniciais de florestas mesófilas, estacionais, matas ciliares, cerrados e carrascos de solo arenoso, bem como em vegetação xerófila, como a caatinga. Na Serra do Cipó foi coletada em área de mata seca decidual, especialmente em áreas associadas a afloramentos de calcários, como na APA Morro da Pedreira.

Trema micrantha apresenta morfologia muito variável e extensa lista de sinônimos (Nevling, 1960), podendo consistir em mais de um táxon. Essa espécie é superficialmente semelhante à Pouzolzia obliqua Wedd., a qual apresenta 4-tépalas e 
aquênio com um simples e longo estilete (Croat, 1978), além de ser frequentemente confundida com $T$. mollis Blume, levando-se a determinações imprecisas (Anderson et al. 36268).

Trema micrantha apresenta pequenos frutos vermelhos, provavelmente dispersos por pássaros. Seu fruto é caracterizado por possuir um pericarpo constituído por parte carnosa pouco espessada e o pireno, de consistência óssea, tem um lóculo fértil e outro reduzido, estéril. Sua semente apresenta endosperma carnoso e embrião curvo, com cotilédones lisos (Barroso et al., 1999).

Esta espécie tem uma notável importância econômica, pois além de ser espécie apícola e indicada como forrageira (Torres \& Luca, 2005), apresenta considerável importância nos reflorestamentos de matas, especialmente por ser uma planta pioneira (Carauta, 1974). Além destas utilidades, sua madeira é muito utilizada como lenha e na fabricação de celulose de qualidade. Sua casca é adstringente, do seu córtex extraemse fibras para preparação de cordoalhas ou tecidos rústicos e seus ramos servem para confecção de cestos. Seus frutos, quando maduros, são muito apreciados por pássaros e servem de engorda para vários animais domésticos (Corrêa \& Penna, 1969).

Ao longo de sua distribuição, floresce e frutifica quase todos os meses do ano, embora na Serra do Cipó tenha sido coletada com flor e fruto de novembro a março. 
Figura 7: A - E. Celtis iguanaea. A. Ramo fértil. B. Flor estaminada. C. Flor bissexuada. D. Detalhe do pedúnculo com fruto. E. Fruto. F - J. Trema micrantha. F. Ramo fértil. G. Flor estaminada. H. Flor pistilada. I. Pedúnculo com frutos. J. Fruto. A C: Pirani CFSC 6691. D: Martins et al. 92. E: Martins et al. 56. F, I e J: Martins et al. 93. H: França 363. 


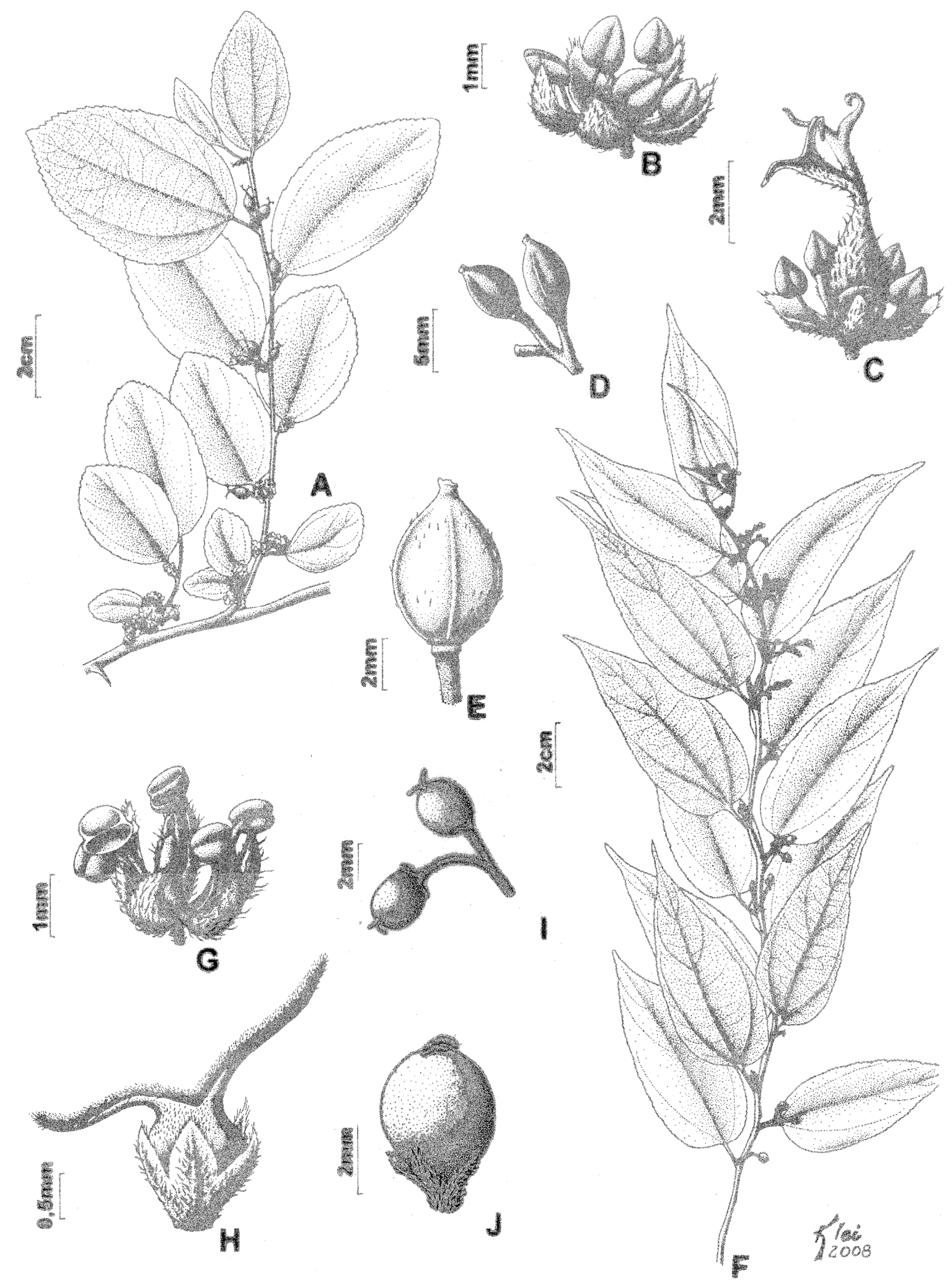




\section{IV.2. MORACEAE Link.}

Árvores, arbustos, lianas lenhosas ou ervas, às vezes epífitas ou hemiepífitas, geralmente latescentes. Folhas simples, raramente compostas, persistentes ou não, alternas, espiraladas ou dísticas, raramente opostas ou verticiladas a rosuladas; lâmina subcoriácea a coriácea ou cartácea, raramente membranácea, basifixa ou peltada, inteira, às vezes lobada, crenada, denteada ou serreada; venação craspedódroma ou camptódroma, raramente actinódroma; pecíolo geralmente presente; estípulas intrapeciolares, raramente interpeciolares, reduzidas a amplas, livres ou fusionadas, frequentemente amplexicaules ou semi-amplexicaules, decíduas ou persistentes, geralmente deixando cicatrizes anulares. Inflorescências bissexuadas ou unissexuadas (plantas monóicas ou androdióicas ou ginodióicas), axilares ou caulifloras, unifloras ou multifloras, bracteadas ou não, cimeiras ou racemos, espigas, pseudo-umbelas, capítulos globosos, fechados ou achatados, sendo dos tipos especiais cenanto (em Dorstenia) e sicônio (em Ficus). Flores actinomorfas, aclamídeas ou monoclamídeas; perianto simples, tépalas livres ou fusionadas, valvadas ou imbricadas, persistentes ou decíduas; flores estaminadas: (2-)4(-5)-tépalas; (1-)3(-4) estames, geralmente isostêmones, às vezes oligostêmones, oposititépalos, curvos ou retos no botão, anteras 2, rimosas, filetes livres ou conatos; pistilódio reduzido ou ausente; flores pistiladas: 0-4tépalas, persistentes, carnosas na maturação; estilete indiviso ou bifurcado, estigma 12; ovário súpero, semi-ínfero ou ínfero, às vezes adnato ao perianto, 1-2-carpelar, unilocular; óvulo basal ou pêndulo, anátropo, hemítropo ou campilótropo, subapical, bitegumentado, crassinucelado; estaminódio ausente. Fruto simples ou composto, drupáceo ou aquênio, às vezes formando sicocarpos ou sincarpos, raramente secos, geralmente envoltos por perianto expandido, suculento e/ou imerso em um receptáculo carnoso; sementes amplas, endosperma presente ou ausente; embrião geralmente curvo ou reto, cotilédones espessos, planos ou dobrados, geralmente desiguais.

Moraceae é uma família de ampla distribuição geográfica, porém concentrada nos trópicos e mais raramente em regiões subtropicais. Compreende aproximadamente 1050 a 1100 espécies distribuídas em ca. 37 gêneros (Berg, 2001; Martins et al., 2007). Na Região Neotropical a família está representada por 19 gêneros e aproximadamente 270 espécies, sendo mais abundante na região central da América do Sul (Berg \& 
Simonis, 2000; Berg \& Villavicencio, 2004). No Brasil essa família é representada por cerca de $30 \%$ dos seus gêneros, concentrados principalmente na Floresta Amazônica (Berg, 2001; Datwyler \& Weiblein, 2004). No presente trabalho, os gêneros Cecropia Loefl., Coussapoa Aubl. e Pourouma Aubl. são tratados na família Urticaceae, conforme o moderno sistema de classificação adotado, ficando a família Moraceae representada na Serra do Cipó por sete gêneros: Ficus L. com cinco espécies e Brosimum Sw., Dorstenia L., Helicostylis Tréc., Maclura Nutt., Pseudolmedia Tréc. e Sorocea St.-Hil. com apenas uma espécie cada na área.

As flores unissexuadas e reduzidas, associadas a limites taxonômicos confusos e ampla variação morfológica das populações de muitas espécies de Moraceae, fizeram da sistemática da família um complexo que urge por mais esforços de campo e por estudos e revisões de seus grupos (Romaniuc-Neto, 1998; Berg, 1978a, 2001; Carauta et al., 2002). Essa situação, conforme já relatado por Castro \& Rapini (2006) para o estado da Bahia, pode ter contribuído para o atual estado precário de conhecimento da família no Brasil. A exemplo desse conhecimento geralmente parcial, no checklist da flora da Serra do Cipó elaborado por Giulietti et al. (1987) foram registradas apenas quatro espécies em apenas um gênero de Moraceae (pois aqui Cecropia e Coussapoa, são tratados em Urticaceae). Com o presente trabalho, esse número aumentou para nove espécies e cinco gêneros.

Moraceae apresenta uma vasta diversidade de usos e importância, sendo várias espécies utilizadas na medicina popular, na fruticultura, na arborização urbana e rural econômica, na construção civil e marcenaria, assim como na fruticultura e ornamental. 


\section{Chave para os gêneros presentes na Serra do Cipó}

1. Plantas herbáceas; inflorescência do tipo cenanto 2. Dorstenia

1'. Plantas lenhosas; inflorescências do tipo sicônio, racemo espiga ou globosocapitadas.

2. Estípulas totalmente amplexicaules; inflorescências bissexuadas.

3. Inflorescências urceoladas (sicônios), com várias flores pistiladas; glândulas baselaminares ou acropeciolares na face abaxial da lâmina

3. Ficus

3'. Inflorescências espigas globosas, com apenas uma a poucas flores pistiladas; ausência de glândulas baselaminares ou acropeciolares na face abaxial da lâmina 1. Brosimum

2'. Estípulas laterais, raramente amplexicaules (Pseudolmedia); inflorescências unissexuadas.

4. Venação semicraspedódroma ou broquidódroma; margem denteada ou espinudada; plantas dióicas; inflorescências racemosas, espigadas ou globosocapitadas, multifloras.

5. Plantas armadas; estames 4, curvos no botão; pistilódio presente.

5. Maclura

5'. Plantas inermes; estames 2-4, retos no botão; pistilódio geralmente ausente.

7. Sorocea

4'. Venação estritamente broquidódroma; margem geralmente inteira; plantas monóicas ou dióicas; inflorescências discóide-capitadas, unifloras.

6. Inflorescências estaminadas sésseis, solitárias; pecíolo glabro a levemente pubérulo; face abaxial glabra a esparsamente pubérula ....6. Pseudolmedia

6'. Inflorescências estaminadas pedunculadas, fasciculadas; pecíolo tomentoso a pubescente; face abaxial densamente tomentosa a pubescente, às vezes levemente hirtela

4. Helicostylis 


\section{Brosimum Sw.}

Árvores ou arbustos, até 10,0 m alt.; ramos cilíndricos; látex alvo a amarelado. Folhas simples, alternas, geralmente dísticas; lâmina inteira, membranácea a coriácea, às vezes cartácea, assimétrica, margem denteada a levemente repanda, glândulas ausentes; venação broquidódroma; pecíolo plano, levemente pubescente a glabro; estípulas livres ou conatas, às vezes totalmente amplexicaules, geralmente decíduas. Inflorescências bissexuadas (plantas monóicas), pedunculadas, globosas a subglobosas ou hemisféricas, convexamente discóides ou turbinadas; brácteas interflorais presentes, peltadas, inicialmente cobrindo o receptáculo; flores estaminadas geralmente numerosas, livres, perianto desenvolvido, tépalas 2-4-lobadas ou partidas, livres ou conatas, às vezes reduzidas, raramente ausentes; estames 1-4, retos no botão, anteras rimosas, às vezes extrorsas; pistilódio ausente; flores pistiladas várias ou única, imersas no receptáculo; tépalas 1-5(-7), às vezes ausentes, estilete e estigma sobressalentes ao receptáculo. Fruto múltiplo (sincarpo) grande, globoso a elipsóide, geralmente suculento na frutificação.

Brosimum compreende um total de 15 espécies espalhados por toda a América tropical e, às vezes subtropical, habitando preferencialmente áreas de cerrado ou savanas (Berg \& Simonis, 2000; Berg, 2001; Kubitzki et al., 1993). Suas espécies apresentam-se subdivididas em dois subgêneros: subg. Ferolia (Aubl.) C.C. Berg caracterizado por estípulas completamente amplexicaules e conatas, e o subg. Brosimum - com estípulas livres e não amplexicaules. Oliveira Filho (2006) catalogou a ocorrência de cinco espécies de Brosimum no estado de Minas Gerais nas categorias "raríssima" a "comum": B. glaucum Taub., B. glazioui Taub., B. guianensis (Aubl.) Huber, B. lactescens (S. Moore) C.C. Berg e B. gaudichaudii Trécul. Na Serra do Cipó ocorre apenas esta última espécie, tida como frequente no domínio do cerrado e atlântico mineiro. 
1.1. Brosimum gaudichaudii Trécul, Ann. Sci. Nat., Bot., sér. 3, 8: 140. 1847.

Nome vernacular: algodãozinho, maminha-cadela, irerê (SP, Lorenzi \& Souza, 2001); mamica-de-cadela (MG, SP, Berg, 1972; Crestana et al., 2006); mamacadela (SP, Jacomassi et al., 2007); mamica-de-porco, mamica-de-cachorra (Lorenzi \& Matos, 2002); apé, mururerana (Carauta et al., 1996); Conduru (CE e PB, Berg, 1972); inharé (CE, GO, PB, MG, Berg, 1972).

Figura 10: A - E.

Árvores ou arbustos, até 4,0 m alt., às vezes até 7,0 m alt.; ramos folhosos 1,0$5,0 \mathrm{~mm}$ larg., acinzentados a amarronzados ou ferrugíneos, pubescentes a hirtelos, às vezes levemente tomentosos; látex fosco, copioso. Lâmina foliar cartácea a subcoriácea ou coriácea, (1,2-)3,5-7,0(-9,0) cm compr., (1,0-)1,5-3,5(-4,5) cm larg., elíptica a oblonga ou lanceolada, levemente assimétrica, geralmente mais ampla acima da metade, ápice obtuso a agudo ou curtamente acuminada, base aguda a obtusa ou levemente subcordada, margem geralmente inteira, às vezes denteada a denticulada, frequentemente revoluta; face adaxial esparsamente pubescente a hirtela, indumento mais concentrado sobre as nervuras; face abaxial pubescente a hirtela ou levemente tomentosa; venação geralmente broquidódroma, levemente proeminente a impressa na face adaxial, proeminente na face abaxial, nervuras secundárias 6-11 pares, terciárias geralmente reticuladas, às vezes reduzidas ou ausentes; pecíolo 0,3-1,0 cm compr., pubescente; estípulas 0,2-0,8 cm compr., pubescentes a tomentosas. Inflorescências pêndulas, globosas a hemisféricas, 2,0-4,5 mm compr., pedúnculo 1,2-3,3 cm compr., glabro a densamente pubescente; brácteas muitas, 0,3-1,8 $\mathrm{mm}$ compr., pubescentes, frequentemente tuberculadas no centro; flores estaminadas: várias, perianto ausente ou semelhante à bráctea; estame 1(-2), circundado pelo perianto; filetes 0,2-0,7 mm compr., anteras 0,2-0,5 mm compr., 0,2-0,4 mm larg., levemente conduplicada, conectivo amplo; flor pistilada: 1, perianto reduzido ou ausente, estilete 0,7-1,5 mm compr., estigmas 0,6-1,0 mm compr. Fruto composto sub-globoso, 1,0-1,8 cm diâm., amarelo a alaranjado na maturidade; semente única, embrião invaginado. 
Material examinado: Itambé do Mato Dentro, distrito de Santana do Rio Preto (Cabeça de Boi), propriedades do José Agostinho, 19²3'46.9"S 4324'07.4"W, M.F. Santos \& L.M. Borges 542, 15.VII.2007, st. (SPF); Jaboticatubas, Serra do Cipó, proximidades da sede do IBAMA, K. Yamamoto \& M.F. Freitas 67, 21.XI.2000, fr. (UEC); proximidades da sede do IBAMA, Serra do Cipó, 19²0'S 4337'W, alt. 600-700 m, cerradão, L.S. Kinoshita \& M.E. Alencar 367, 21.XI.2000, fr. (UEC); Santana do Riacho, distrito de Cardeal Mota, trilha para a Cachoeira dos Gaviões e da Farofa, 1920'35"S 4335'15"W, campo rupestre e cerrado, K. Yamamoto et al. 111, 27.IX.2002, fl. (UEC); Serra do Cipó, logo depois do Rio Cipó, cerrado, J.A. Lombardi \& F.R.N. Toledo 454, 20.X.1993, fl., fr. (BHCB, MBM).

Material adicional: Bahia, Barreiras, BR-242, km 774, em direção a lbotirama, beira da

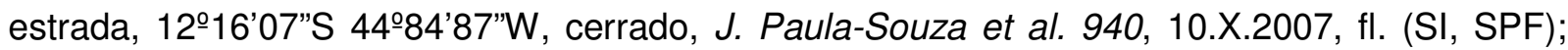
Chapada Diamantina, Rio de Contas, estrada de acesso ao Pico das Almas, 1331'05"S 4154'27'W, cerrado rochoso, N. Roque et al. 970, 6.XII.2003, fr. (ALCB, SPF). Goiás, Chapadão do Céu, Parque Nacional das Emas, à 4 km do portão Jacuba, J. Paula-Souza 8367 et al., 11.X.2006, fl., fr. (SPF). Tocantins, Pindorama do Tocantins, estrada para Ponte Alta do Tocantins, ca. 24 km de Pindorama, 1100'68”S 4749'94"W, J. Paula-Souza et al. 9047, 6.X.2007, fl., fr. (CTES, SI, SPF).

Brosimum gaudichaudii Tréc. distribui-se principalmente na América tropical desde a Amazônia brasileira a Bolívia e leste do Paraguai. No Brasil distribui-se do nordeste da Bacia Amazônica, ocorrendo em áreas isoladas, passando pelo cerrado típico, cerradão e áreas abertas do Brasil central ao leste brasileiro, aqui crescendo em áreas degradadas, florestas secundárias e matas de transição (Almeida et al., 1998; Berg, 2001). No estado de Minas Gerais é frequente no domínio atlântico do Vale do Jequitinhonha e Vale do Rio Doce e no domínio do cerrado na Cadeia do Espinhaço (Oliveira Filho, 2006). Na Serra do Cipó ocorre principalmente nos cerrados e campos rupestres e nos campos abertos ao longo das trilhas para a Cachoeira dos Gaviões e da Farofa, no interior do PARNA Serra do Cipó.

Embora em Brosimum predominem espécies arbóreas, muitos exemplares de $B$. gaudichaudii são arvoretas ou mesmo arbustos dos campos e cerrados. Os indivíduos dessa espécie são facilmente identificados pelas inflorescências geralmente pêndulas e globosas, e pelas folhas cartáceas a coriáceas, com látex alvo abundante. No entanto, conforme observado por Berg (1972), a dimensão de suas folhas é muito variável, 
podendo o mesmo espécime apresentar folhas pequenas e grandes, sendo as pequenas freqüentemente achadas em ramos laterais curtos próximas ao pedúnculo da inflorescência.

Sua madeira é freqüentemente utilizada para lenha e carvão, tendo em vista sua baixa densidade, e seus frutos são comestíveis, com aromas adocicados e apreciados no Brasil Central (Lorenzi, 2002; Crestana et al., 2006). Na medicina popular, o extrato das raízes, casca do caule e folhas são amplamente empregados contra o vitiligo e outras manchas na pele em várias regiões do país (Lorenzi \& Matos, 2002; Rodrigues \& Carvalho, 2001). Neste aspecto, Jacomassi et al., (2006) verificaram que a importância medicinal atribuída à droga vegetal extraída de $B$. gaudichaudii pode ser diagnosticada facilmente pela coloração marrom-avermelhada de suas raízes geminíferas, odor característico e pelo súber com camadas facilmente destacadas.

Floresce geralmente o ano todo, mas na Serra do Cipó são encontrados indivíduos florescendo principalmente em setembro e outubro, e frutificando em novembro a janeiro. 


\section{Dorstenia L.}

Ervas até $0,8(-1,3) \mathrm{m}$ alt., rizomatosas, às vezes tuberosas, latescentes; entrenós curtos ou alongados. Folhas simples, alternas, espiraladas ou rosuladas; lâmina inteira ou lobada a partida, basifixa ou peltada, margem frequentemente denteada a crenada; venação broquidódroma ou actinódroma; pecíolo levemente canaliculado, glabro a minutamente pubescente; estípulas membranáceas a coriáceas, laterais, geralmente persistentes. Inflorescência um cenanto bissexuado (plantas monóicas), solitário, axilar, pedunculado, discóide a orbicular, elíptico a arredondado ou quadrangular, verde-amarelado a marrom-avermelhado, margem inteira ou lobada, com verticilos de brácteas marginais, apêndices filiformes geralmente presentes; flores conatas; brácteas interflorais ausentes ou rudimentares; flores estaminadas: tépalas 23, lobadas, geralmente livres, pediceladas, conatas ao perianto das flores pistiladas; estames 1-2(-4), inflexos no botão, retos e exsertos posteriormente; pistilódio ocasionalmente presente; flores pistiladas: tépalas 2-3, lobadas, tubulares, livres na parte apical, sésseis; ovário livre; estigma bífido, curtamente filiforme, às vezes ramos de comprimentos desiguais. Fruto drupas deiscentes reunidas no receptáculo espessado do cenanto, exocarpo carnoso ou suculento, endocarpo crustáceo a verrucoso; semente pequena, testa delgada, endosperma presente.

O gênero Dorstenia apresenta distribuição pantropical, com aproximadamente 344 espécies concentradas principalmente na África. Ocorre desde o norte do México ao sul do Uruguai e Argentina, tendo sido registradas 46 espécies na América tropical (Berg \& Simonis, 2000; Berg 2001). No Brasil ocorrem aproximadamente 37 espécies (Berg, 2001; Carauta, 1978; Carauta et al., 1996; Carauta et al., 2002), habitando principalmente na floresta amazônica, no cerrado, na caatinga e nas diversas fisionomias da floresta atlântica.

Dorstenia foi estabelecido por Linnaeus ainda no século XVIII quando da descrição de Dorstenia contrajerva L. (Carauta, 1978). Nesta época apenas quatro espécies foram descritas, entre elas D. brasiliensis Lam. e D. tubicina Ruiz \& Pav., tratadas como sinônimos por Berg (2001) no tratamento taxonômico para a Flora Neotropica. Na Serra do Cipó há apenas dois registros antigos de ocorrência de $D$. brasiliensis sensu Berg (2001). 
Espécies de Dorstenia neotropicais são principalmente herbáceas e monóicas (Berg, 2001), com caule subterrâneo ou aéreo, raízes adventícias partindo do rizoma, folhas simples, alternas e estipuladas, inflorescências do tipo cenanto, com forma e coloração variadas (Carauta et al., 1974; Carauta, 1978). Suas flores pistiladas e estaminadas variam na forma e número entre as diferentes espécies (Granville, 1971), sendo as pistiladas, juntamente com seu estigma bífido e ovário, imersas nos alvéolos do cenanto e as estaminadas geralmente dispostas na sua periferia (Granville, 1971; Carauta et al., 1974; Carauta, 1978; Berg, 2001).

\subsection{Dorstenia brasiliensis Lamarck, Encycl. 2: 317. 1786.}

Nome vernacular: caiapiá, carapiá (GO e TO, Martins et al., 2007); liga-liga, tarope (MA, DF, GO, MG, Carauta et al., 1996); batatinha-de-teiú (BA, Castro, 2006).

Figura 8: A.

Erva, ca. $5 \mathrm{~cm}$ alt., caule subterrâneo, cilíndrico, (1,0-)3,0-10,5 mm larg., levemente tuberoso, glabro, entrenós curtos, odorífero. Folhas rosuladas, às vezes espiraladas; lâmina cartácea a levemente coriácea, (1,0-)2,5-6,3(-10,0) cm compr., (0,71,0-2,7(-4,0) cm larg., oblonga a elíptica ou obovada a lanceolada, ápice arredondado a obtuso ou levemente agudo a acuminado, base cordada a truncada, raramente obtusa, margem irregularmente crenada a crenulada; face adaxial escabra a lisa, às vezes esparsamente hirtelo a estrigoso; face abaxial pubescentes a hirtelo ou levemente tomentoso sobre as nervuras; venação geralmente craspedódroma, impressa na face adaxial, proeminente na abaxial, nervuras laterais 5-12 pares; pecíolo $(0,5-) 1,3-6,5(-8,0) \mathrm{cm}$ compr., hirsuto a pubescente; estípulas triangulares, 0,2-0,7 cm compr., coriáceas, esparsamente hispidulosa. Inflorescência ereta ou pêndula, 4,5-17,3 cm compr., esverdeada a rosada; pedúnculo (0,7-)1,5-9,3(-12,5) cm compr., hirsuto a hirteloso; cenanto 0,8-2,5 cm diâm., discóide a orbicular, margem geralmente inteira, às vezes crenada; 1-3 verticilos bracteais na margem; flores estaminadas: tépalas 2, 0,30,6 mm compr., 0,2-0,5 mm larg., livres ou conatas na base, cuculadas; estames 2, curvos no botão, filetes curtos, anteras basifixas; flores pistiladas: tépala 1, 1,5-2,3 mm compr., 0,4-0,8 mm larg., tubular; ovário livre, estilete filiforme, glabro, estigma bífido. 
Drupa pequena, 1,5-2,5 mm compr., 1,7-2,7 mm larg., esbranquiçado, endocarpo levemente tuberculado.

Material examinado: Serra do Cipó, Heringer-Castellanos s.n., 3.III.1958 (HERB 5964, SP); km 138, alt. 1800 m., Duarte, A.P. 2274, 9.XII.1949 (RB).

Material adicional: Minas Gerais, Buenópolis, Curimataí, Simão, 1,8 km ao sul da Praça do Jatobá, em Curimataí, margens do Rio Simão, próximo a cachoeira em córrego que deságua no Rio Simão, sopés da Cadeia do Espinhaço, 17ํ5'44"S 435ㄱ'25"W, 562 m alt., R. MelloSilva et al. 2528, 27.I.2004, fl., fr. (MBM, NY, R, SPF); Datas, Rodovia Datas-Serro, Morro do Coco, 1826'S 4341'W, 1300-1330 m alt., R. Mello-Silva et al. CFCR 11731, 8.I.1988, fl., fr. (SPF); Diamantina, próximo ao antigo leito da estrada de ferro de Guinda, $R$. Simão et al. CFCR 11774, 9.I.1988, fl., fr. (GUA, SPF); Lagoa Santa, Fazenda Olhos D’Água, Luiz Roth 14632, 20.XI.1962, fl., fr. (BHCB, CESJ). São Paulo, São Paulo, Cidade Universitária, J.R. Pirani et al. s.n, 27.X.1987, fl. (SPF 49021).

Dorstenia brasiliensis Lam. ocorre do norte da Argentina e Uruguai até o Peru e Bolívia, Colômbia, Venezuela e Guiana Francesa (Berg \& Simonis, 2000; Castro, 2006). No Brasil é encontrada nas áreas úmidas dos cerrados, caatinga e restingas abertas, assim como nas florestas Amazônica e Atlântica. Na Serra do Cipó floresce de maio a setembro.

Indivíduos de $D$. brasiliensis Lam. apresentam ampla variação morfológica em suas estruturas vegetativas e reprodutivas, o que tem dificultado sua identificação e a delimitação específica. Diante dessa grande variabilidade, e pelo fato de o gênero apresentar inúmeros táxons com diagnoses imprecisas, Berg (2001) sinonimizou vários desses táxons em $D$. brasiliensis Lam, como comentado para o gênero.

$\mathrm{Na}$ Serra do Cipó são registradas apenas as duas coletas de Dorstenia supracitadas. Uma delas poderia ser identificada como D. tubicina Ruij \& Pavou (Duarte 2274), e a outra como D. heringeri (Heringer-Castellanos s.n., HERB 5964). Porém aqui se adota a circunscrição específica proposta por Berg (2001), com aqueles dois binômios sinonimizadas sob $D$. brasiliensis.

Relatam-se o uso de caule e folhas dessa espécie na medicina popular para diversos fins, destacando-se: expectorante, repelente para cobras e curativa da doença-de-chagas, assim como na celebração de cultos afro-brasileiros (Castro, 2006; Pio-Corrêa, 1984). 


\section{Ficus $\mathrm{L}$.}

Árvores a arbustos, terrestres ou hemiepífitas, até $40 \mathrm{~m}$ alt.; raízes aéreas frequentemente presentes, anastomosadas; látex presente em toda planta, escasso ou espesso. Folhas simples, alternas, espiraladas, raramente dísticas, subopostas ou subverticiladas; lâmina inteira, 1 a 2 glândulas acropeciolares ou baselaminares geralmente presentes; venação broquidódroma; margem inteira, raramente denteada; pecíolos planos ou levemente canaliculados; estípulas geralmente terminais, totalmente amplexicaules, decíduas ou persistentes, deixando cicatriz horizontais. Inflorescência unissexuada (funcionalmente) ou raramente bissexuada (plantas monóicas ou ginodióicas - funcionalmente estaminadas ou pistiladas), receptáculo urceolado formando um cenanto côncavo ou fechado (sicônio), axilar, solitário ou aos pares, séssil ou pedunculado; ostíolo proeminente, plano, crateriforme ou anel circular a triangular; orobrácteas externas 2-6, geralmente imbricadas ou não, frequentemente glabras ou pubescentes; epibrácteas 2-3, triangulares ou levemente arredondadas; bractéolas interflorais presentes. Flores estaminadas numerosas, sésseis ou pediceladas; tépalas 2-6, livres ou conatas na base; estames 1 ou 2(-3), anteras rimosas, 2-tecas, dorsifixas; pistilódio presente ou ausente. Flores pistiladas várias, sésseis ou pediceladas; tépalas 2-4, livres ou conatas na base; ovário súpero, livre, 1-locular, 1-ovulado; estilete 1, inteiro, lateral, diferentes comprimentos na mesma inflorescência; estigmas 1-2, levemente filiforme. Fruto drupa pequena ou às vezes aquênio, globoso a oval, exocarpo levemente membranáceo; semente pequena, endosperma presente.

O gênero Ficus compreende aproximadamente 750 espécies distribuídas principalmente nas regiões tropicais e subtropicais do mundo. Estas se distribuem pela Ásia e Australásia (com aproximadamente 500-550 espécies), 105 pela África e por volta de 120 espécies na região Neotropical (Berg, 2001; Berg \& Villavicencio, 2004). Das espécies neotropicais, 64 são referidas para o Brasil (Berg \& Villavicencio, 2004). Em estudo de mapeamento e inventário da flora nativa e dos reflorestamentos em Minas Gerais, Oliveira-Filho (2006) catalogou 22 espécies de Ficus no estado.

As espécies de Ficus são caracterizadas, principalmente, pelo hábito arbóreo ou hemiepifítico; presença de látex leitoso e viscoso em todas as partes da planta; folhas 
com glândulas na base da lâmina (baselaminar) ou no pecíolo (acropeciolar); estípulas terminais bem desenvolvidas e geralmente amplexicaules e, sobretudo, pela inflorescência do tipo sicônio, isto é, uma inflorescência bissexuada, cimosa, com um receptáculo completamente urceolado (semelhante a um cenanto fechado), envolvendo as numerosas e diminutas flores estaminadas e pistiladas na antese. Os sicônios são popularmente denominados de figos, e as plantas que os produzem conhecidas como figueiras ou gameleiras.

No presente trabalho são reconhecidas 5 espécies de Ficus na Flora da Serra do Cipó. Segundo a classificação de Corner (1962), apenas uma delas (F. obtusiuscula (Miq.) Miq.) pertence ao subgênero Pharmacosycea (Miq.) Miq., enquanto as 4 outras se incluem no subg. Urostigma (Gasp.) Miq.

Os dois subgêneros de Ficus ocorrentes na Flora da Serra do Cipó são assim caracterizados:

Ficus subg. Pharmacosycea (Miq.) Miq. - geralmente arbóreas, raramente hemiepífitas, desprovidos de raízes aéreas; face abaxial da lâmina foliar com duas glândulas baselaminares; sicônio geralmente solitário, porém podendo ocorrer aos pares, geralmente com 3 brácteas basais; estames 2-3; flores pistiladas geralmente com 2 estigmas;

Ficus subg. Urostigma (Gasp.) Miq. - árvores ou arbustos, frequentemente hemiepífítas; face abaxial da lâmina foliar com uma glândula acropeciolar; sicônios geralmente pareados, receptáculo geralmente subtendido por 2 brácteas basais; flores estaminadas com 1 estame e sem pistilódio e pistiladas com 1 estigma.

No presente trabalho adota-se o estudo de Mello-Filho et al. (2001) para descrever a morfologia do sicônio e de algumas das suas estruturas, a saber: tegilo bráctea solitária, decídua, semelhante a uma caliptra ou capuz que protege os sicônios quando jovens; epibrácteas - brácteas que estão posicionadas na base do sicônio, na porção distal do pedúnculo; orobrácteas - brácteas inseridas e arranjadas ao redor da abertura do sicônio, o ostíolo; e bractéolas - brácteas dispostas entre as flores no interior do sicônio. 


\section{Chaves para as espécies de Ficus presentes na Serra do Cipó}

1. Árvores, raramente hemiepífitas; raízes aéreas ausentes; 2 glândulas baselaminares na face abaxial da folha; 3 estames 3.4. F. obtusiuscula

1'. Árvores, geralmente hemiepífitas; raízes aéreas presentes; 1 glândula acropeciolar na face abaxial; 1 a 2 estames.

2. Epibrácteas glabras internamente; estípulas glabras internamente.

3. Ramos 0,3-0,7 cm larg.; lâmina foliar 3,0-9,5 x 1,3-4,5 cm, face abaxial glabra, às vezes esparsamente pubescente sobre a nervura principal; pecíolo geralmente glabro; ostíolo crateriforme .........................................5. F. pertusa

3'. Ramos 0,4-1,7 cm larg.; lâmina foliar 7,5-29,7 x 4,5-19,5 cm, face abaxial densamente pubescente a hispidulosa, indumento mais concentrado sobre as nervuras; pecíolo densamente pubescente; ostíolo proeminente em anel circular

3.2. F. gomelleira

2'. Epibrácteas seríceas, tomentosas a vilosas; estípulas seríceas internamente.

4. Lâmina foliar ovada a elíptica, base subcordada a cordada; face abaxial densamente pubescente a tomentosa

3.1. F. calyptroceras

4'. Lâmina foliar obovada a oblonga, base cuneada a obtusa; face abaxial glabra 3.3. F. obtusifolia 
3.1. Ficus calyptroceras (Miq.) Miq., Ann. Mus. Bot. Lugd.-Bat. 3: 297. 1867.

Nome vernacular: gameleira, figueira (Lorenzi, 2002); gameleira-branca (GO e TO, Martins et al., 2007; Carauta \& Diaz, 2002a); figueira-branca (GO e TO, Martins et al., 2007)

Figura 8: $\mathrm{B}-\mathrm{I}$.

Árvores, hemiepífitas, 3,5 a 18,0 m alt:; raízes aéreas presentes; ramos 0,6-1,5 cm larg., angulares a levemente eretos, rugosos a canaliculados, glabros a levemente pubescentes ou tomentosos, marrom-acinzentados a esbranquiçados, periderme às vezes desprendendo-se. Lâmina foliar coriácea, (4,2-)9,3-13,8(-15,5) cm compr., (4,36,5-10,2(-12,3) cm larg., cordiforme ou ovada a elíptica, ápice arredondado a obtuso ou levemente subagudo, base cordada a subcordada, margem inteira, geralmente revoluta; face adaxial glabra a esparsamente hirsuta, levemente pubescente ao longo das nervuras e densamente na base da nervura primária, lisa a levemente rugosa ao toque; face abaxial densamente pubescente a tomentosa sobre as nervuras, alva a pálidoferrugínea, macia ao toque, glândula acropeciolar presente; venação broquidódroma, nervura principal geralmente não atingindo o ápice, nervuras laterais 6-10 pares, pares basais distintos, ramificados, demais nervuras laterais geralmente furcadas distalmente, venação terciária reticulada a escalariforme; pecíolo (1,4-)2,5-4,3(-5,8) cm compr., (1,22,0-3,5(-5,2) cm larg., levemente pubescente, raramente glabro, castanho-acinzentado a marrom-ferrugíneo, levemente canaliculado, periderme persistente ou desprendendo distalmente; estípulas 0,4-1,3 cm compr., densamente tomentosas a vilosas, seríceas internamente, alvas a castanho-ferrugíneas, às vezes decíduas, macias ao toque. Sicônios subglobosos a globosos, 0,6-1,5 cm compr., 0,5-1,3 cm larg., axilares, sésseis, aos pares, inicialmente envoltos por caliptra, levemente a densamente pubescente, raramente glabros, alvos a acinzentados, máculas esverdeadas a marrom-enegrecidas ou avermelhadas; epibrácteas 4,2-1,0 mm compr., 3,5-6,3 mm larg., densamente seríceas a vilosas interna e externamente, alvas a levemente castanho-ferrugíneas, fusionadas, às vezes separadas, triangulares a arredondadas, ápice levemente agudo, margem serícea; ostíolo 1,5-2,7 mm diâm., geralmente proeminente, raramente plano; orobrácteas geralmente 3, caliptriformes, densamente pubescentes a levemente seríceas, geralmente glabras internamente, alvas a castanho-avermelhadas; bractéolas 
0,5-1,2 mm compr., 0,3-0,7 mm larg., triangulares a lanceoladas, alaranjadas a cremeavermelhadas. Flores estaminadas: pediceladas, (0,7-)1,2-1,5(-1,8) mm compr., 0,4-0,8 $\mathrm{mm}$ larg.; tépalas 3, alaranjadas a creme-avermelhadas, glabras; estame 1. Flores pistiladas: sésseis ou pediceladas, (1,2-)2,3-3,0(-4,5) mm compr., 0,5-1,2 mm larg., tépalas (2-)3(-4), fusionadas ou não na base; estigma penicelado, alaranjado a avermelhado. Drupa subglobosa a ovóide, 0,8-1,7 mm compr., 0,5-1,5 mm larg., cremeamarelada a alaranjada; semente 1, ovóide, alaranjada.

Material examinado: Cardeal Mota, Morro da Pedreira (2ำ Grupo), afloramentos de calcários na base da Serra do Cipó, Fazenda Canto da Serra, J.R. Pirani et al. CFSC 13274, 22.VII.1993, fl., fr. (SPF); afloramentos de calcários, D.C. Zappi et al. CFSC 10452, 7.IX.1987, fl., fr. (GUA, SPF); APA Morro da Pedreira, alto dos afloramentos de metacalcário (blocos do

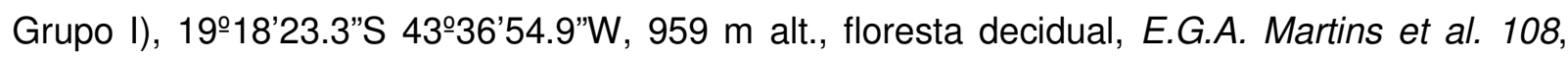
23.V.2007, fl., fr. (SPF); 1918'29.6”S 4336'52.5”W, $924 \mathrm{~m}$ alt., E.G.A. Martins et al. 42, 24. IX.2006, fl., fr. (SPF); 19¹8'19.3”S 433'50”W, 920 m alt., E.G.A. Martins et al. 51, 17.I.2007, fl., fr. (SPF); Santana do Riacho, ao longo da rodovia Belo Horizonte - Conceição do Mato Dentro, estrada de acesso ao Morro do Calcário, M.L. Kawasaki et al. CFSC 7605, 7.X.1981, fl., fr. (SP, SPF); Serra do Cipó (Serra da Lapa), distrito São José da Cachoeira, afloramentos de calcários na estrada Santana do Riacho - Santana do Pirapama, V.C. Souza et al. 32887, 20.II.2007, fl. (ESA, SPF).

Material adicional: Bahia, entre Bom Jesus da Lapa e Riacho de Santana, rodovia BA430, 1329'21"S 4305'31"W, ca. $535 \mathrm{~m}$ alt., base de afloramento rochoso, M. Groppo Jr. et al. 724, 15.V.2001, fl., fr. (F, SPF). Minas Gerais, Matozinhos, Fazenda Caucaia, afloramento de calcário, J.A. Lombardi 1425, 31.X.1996, fl., fr. (BHCB, SPF).

Ficus calyptroceras possui ampla distribuição geográfica, estendendo-se principalmente do Brasil Central ao leste da Bolívia, Paraguai e norte da Argentina, em matas mesófilas semidecidual e decidual, em campo-cerrado ou cerrado (Berg, 2001; Berg \& Villavicencio, 2004). No Brasil é citada para os estados da Bahia, Goiás, Minas Gerais, Piauí, Mato Grosso do Sul e Tocantins, frequentemente associadas a rochas calcárias e basálticas acima de $800 \mathrm{~m}$. No Nordeste é muito comum na caatinga arbórea do vale do Rio São Francisco. Na Serra do Cipó ocorre na orla ou no interior de matas decidual associadas a afloramentos de calcários, sendo muito comum na Área 
de Proteção Ambiental Morro da Pedreira, complexo orográfico constituído por afloramentos de calcário com 880-940 m altitude, que antigamente sediava uma mineradora.

A preferência da espécie por substratos rochosos carbonáticos já foi constatada por outros autores como Carauta et al. (1996) e Berg \& Villavicencio (2004). Em estudo sobre as florestas estacionais decidual a oeste da Cadeia do Espinhaço, Meguro et al. (2007) identificaram F. calyptroceras em quatro áreas de afloramentos calcários. Nesse mesmo estudo, F. calyptroceras obteve especial destaque por ser grande árvore cuja semente germina em fendas na rocha carbonática, muitas vezes no topo do afloramento, à plena insolação, e cedo instala longas raízes diretamente sobre ela, formando tronco robusto e copa ampla (Meguro et al., 2007).

Essa espécie foi descrita inicialmente por Miquel (1847) sob o nome Urostigma calyptroceras, com base num espécime coletado por Gardner em 1830 no município de Parnaguá, Piauí. Seu epíteto específico está associado às palavras gregas calyptra e ceras que significam cápsula e chifre, em referência ao formato das epibrácteas (Carauta \& Diaz, 2002a).

A presença de tricomas na face abaxial das orobrácteas dessa espécie é reportada também nas espécies $F$. membranacea C. Wright, F. eximia Schott, $F$. catappifolia Kunth \& C.D. Bouché e F. obtusifolia Kunth, podendo tratar-se de caráter indicador de proximidade filogenética entre elas (Berg \& Villavicencio, 2004).

Os frutos de $F$. calyptroceras tem se mostrado relevantes para animais frugívoros, especialmente durante a estação seca, quando os frutos carnosos tendem a ser escassos, principalmente nas matas secas associadas a rochas calcárias. RagusaNeto (2002) estudando a fenologia da frutificação e consumo de figos de $F$. calyptroceras por aves verificou o papel relevante que essa espécie desempenha para a comunidade de aves frugívoras, principalmente pelo fato de ser altamente explorado pela avifauna e devido ao seu padrão assincrônico de frutificação. 
3.2. Ficus gomelleira Kunth \& C.D. Bouché, Ind. Sem. Hort. Berol. (1946): 18. 1847. Albertoa 10, série Urticineae (Urticales): 67-68. 2002.

Nome vernacular: figueira, gomeleira (Romaniuc-Neto, 1996); gameleiravermelha (SP, Mendonça-Souza, 2006); gameleira (RJ, Carauta, 1989; 1996; Carauta \& Diaz, 2002a)

Figura 9: $\mathrm{A}-\mathrm{H}$.

Árvores, às vezes hemiepífitas, 8,0 a 15,0 m alt.; raízes adventícias presentes; ramos 0,4-1,7 cm larg., angulares, lisos, levemente canaliculados, pubescentes a glabros em direção a base dos ramos, ferrugíneos a castanho-avermelhados, periderme persistente, às vezes desprendendo-se na base. Lâmina foliar subcoriácea a coriácea, (7,5-)13,3-18,5(-29,7) cm compr., (4,5-)7,2-12,7(-19,5) cm larg., elíptica a oblonga, às vezes obovada, ápice arredondado a levemente agudo a acuminado, base arredondada a subcordada, margem inteira, levemente revoluta; face adaxial glabra a esparsamente hispidulosa, diminutamente hispidulosa sobre as nervuras, lisa ao toque; face abaxial densamente pubescente a hispidulosa, indumento mais concentrado sobre as nervuras, amarelo a ferrugíneo, macio ao toque, glândula acropeciolar geralmente presente; venação broquidódroma, nervuras laterais 7-10(-13) pares, ângulos iguais, proeminentes na face abaxial, venação terciária reticulada; pecíolo (1,3-)2,0-3,2(-5,3) cm compr., 0,2-0,7 mm larg., densamente pubescente, ferrugíneo a castanhoalaranjado, periderme desprendendo-se na base, às vezes persistente, às vezes canaliculado; estípula $(0,5-) 0,8-1,5(-2,3) \mathrm{cm}$ compr., densamente tomentosa, ferrugínea a castanho-avermelhada, glabra internamente, às vezes decídua, macia ao toque. Sicônios globosos a subglobosos, 0,5-1,3(-2,0) cm compr., 0,6-1,0(-1,8) cm larg., axilares, geralmente aos pares, esbranquiçados a alvo-castanhos; caliptra geralmente presente, densamente pubescente a tomentosa, ferrugínea a castanho-avermelhada, máculas enegrecidas; pedúnculos 0,3-1,0(-1,5) cm compr.; epibrácteas 2, 3,3-6,0 mm compr., 3,0-5,2 mm larg., densamente tomentosas a pubescentes, glabras internamente, ferrugíneas a castanho-alaranjadas, levemente lobadas, geralmente separadas, raramente fusionadas na base, arredondadas, ápice levemente agudo, margem glabra; ostíolo 1,7-2,5 mm diâm., anel circular proeminente; orobrácteas 2, às vezes ausentes, glabras, creme a castanhas; bractéolas 0,5-1,0(-1,7) mm compr., 0,2- 
0,5 mm larg., oblongas, alvas a creme-transparentes. Flores estaminadas: 0,7-1,5 mm compr., 0,4-1,0 mm larg.; tépalas 4, 2 em forma de caliptra, raramente fusionadas na base, alaranjadas a castanho-avermelhadas, glabras, pediceladas; estame 1, rimoso. Flores pistiladas: tépalas 3, 1 em forma de caliptra, raramente fusionadas na base, alaranjadas a castanho-avermelhadas; estigma 1, plumoso, bifurcado; flores pediceladas: pedicelo curto e espesso; (0,3-)0,7-1,3 (-1,7) mm compr., 0,3-0,8 mm diâm., estilete curto; flores sésseis: 0,7-1,8 mm compr., 0,3-1,0 mm larg., estilete longo. Drupa globosa, 0,6-1,0 mm compr., 0,3-0,8 mm larg., creme-amarelada a alaranjada; semente 1, ovóide, creme-alaranjada.

Material examinado: Minas Gerais, Itambé do Mato Dentro, distrito de Santana do Rio Preto (Cabeça de Boi), 19²4'40.4"S 4325'20.9"W, M.F. Santos \& E.G.A. Martins 162, 25.VIII.2007, fl., fr. (SPF).

Material adicional: Bahia, Itanhém, Corró, na base de afloramentos rochosos, 17ำ'15”S 4012'37.1'W, $300 \mathrm{~m}$ alt., J.R. Stehmann et al. 3785, 17.VIII.2004, fl., fr. (BHCB, SPF). Minas Gerais, Gurinhatã, BR-364, área de transição entre Cerradão e Floresta Estacional Semidecidual, 1913'37"S 5001'08”W, 522 m alt., L.F.M. Coelho et al. 7, 24.V.2007, fl. (SPF, SPFR); São Roque de Minas, arredores do Parque Nacional da Serra da Canastra, 2015'62”S 4624'58”W, 1095 m alt., A.M. Giulietti et al. CFCR 13595, 12.I.1994, fl., fr. (K, MBM, NY, SPF). São Paulo, Juquiá, Fazenda Poço Grande, M. Kuhlmann 3114, 26.XI.1954, fr. (SPF).

Ficus gomelleira Kunth \& C.D. Bouché apresenta ampla distribuição predominantemente tropical, ocorrendo também em regiões subtropicais. Ocorre nas Antilhas, Trinidad, na Venezuela, Suriname, Guiana, Guiana Francesa, Colômbia, Peru, Equador, Bolívia e Brasil, habitando florestas úmidas de baixas altitudes. No Brasil ocorre nos estados do Acre, Amazonas, Amapá, Bahia, Espírito Santo, Goiás, Maranhão, Mato Grosso, Minas Gerais, Pará, Paraná, Piauí, Rio de Janeiro, Rio Grande do Sul, Rondônia, Santa Catarina, São Paulo e Distrito Federal (Carauta \& Diaz, 2002a; Berg \& Villavicencio, 2004; Carauta, 1989; Martins et al., 2007). Na Serra do Cipó ocorre apenas na face leste dos altiplanos, em floresta estacional semidecidual de baixa altitude.

Ficus gomelleira é facilmente identificada pela copa ampla, pelas folhas com venação proeminente na face abaxial, e pela pilosidade marrom a ferrugínea na 
estípula, no sicônio, no pecíolo, na lâmina foliar coriácea e, às vezes, também nos ramos.

Berg \& Villavicencio (2004) comentam que a espécie é constantemente confundida com F. crocata (Miq.) Miq., principalmente por aspectos relacionados à morfologia do sicônio. Entretanto, os autores as diferenciam por características da venação foliar e do indumento da estípula e formato da lâmina foliar.

Miquel (1847) em publicação no Prodromus monographie Ficuum aceita Kunth \& Bouché como os autores das espécies de Ficus publicadas no Index Seminum in Horto Botanico Berolinensi anno 1846 Collectorum de 1847, sendo seguido por sicólogos como Berg et al. (1984), Carauta (1989), Berg \& Simonis (2000) e Berg \& Villavicencio (2004). No entanto, após estudo do trabalho de Kunth (1847), Carauta \& Diaz (2002b) complementam a descrição de F. gomelleira adicionando a descrição dos sicônios e efetuam a correção dos autores da espécie a apenas Kunth. Desta forma, estes autores propuseram a adição da partícula emendavit ao nome da esécie: Ficus gomelleira Kunth emend Carauta \& Diaz. Entretanto, segundo o artigo 47 do Código Internacional de Nomenclatura Botânica (McNeill et al., 2006) alterações na característica disposta em um táxon sem excluir o tipo não implica mudanças na citação da autoridade. Por isso no presente trabalho adota-se Ficus gomelleira Kunth \& C.D. Bouché, assim como fizeram Berg \& Villavicencio (2004) e Berg \& Franco-Rosselli (2005). 
3.3. Ficus obtusifolia Kunth, in Humbold \& Bonpland, Nov. Gen. Sp. PI. 2: 49. 1817.

Nome vernacular: figueira, pau-de-gamela (SP, Mendonça-Souza, 2006; Carauta, 1989).

Figura 8: $\mathrm{J}-\mathrm{P}$.

Árvores, hemiepífitas, 4,0 a 15,0 m alt.; raízes adventícias às vezes presentes; ramos $0,7-1,3 \mathrm{~cm}$ larg., angulares a levemente eretos, rugosos a canaliculados, glabros a levemente pubescentes, marrom-acinzentados a castanho-avermelhados, periderme geralmente persistentes. Lâmina foliar coriácea a cartácea, (6,5-)10,3-20,5(-32,3) cm compr., (4,0-)7,5-11,3(-17,3) cm larg., obovada a oblonga, raro oblanceolada a elíptica, ápice arredondado a obtuso, às vezes levemente sub-acuminado, base cuneada a obtusa, margem inteira, levemente revoluta; face adaxial geralmente glabra, às vezes esparsamente pubescente sobre a nervura principal, lisa a levemente rugosa ao toque; face abaxial glabra, às vezes diminutamente pubescente sobre a nervura principal, lisa a levemente rugosa ao toque, glândula acropeciolar presente; venação broquidódroma, nervuras laterais 5-8(-9) pares, venação terciária reticulada; pecíolo (1,8-)2,5-5,3(-9,0) cm compr., (0,8-)1,5-3,2(-5,0) mm larg., diminutamente pubescente, raro glabro, esverdeado a castanho-acinzentado, levemente canaliculado, periderme persistente; estípulas (0,8-)1,2-2,3 cm compr., densamente tomentosas a vilosas externamente, alvas a castanho-ferrugíneas, glabras a seríceas internamente, às vezes decíduas, macias ao toque. Sicônio subgloboso a globoso ou elipsóide, 1,2-2,3 cm compr., 1,0-1,7 cm larg., axilar, séssil ou pedúnculo até 0,6 cm compr., aos pares, inicialmente envolto por caliptra, densamente pubescente, alvo a acinzentado com máculas alaranjadas a marrom-avermelhadas; epibrácteas 2, 4,3-6,0 mm compr., 4,5-8,3 mm larg., densamente tomentosas externamente, seríceas a vilosas internamente, alvas a levemente castanho-ferrugíneas, geralmente separadas, às vezes fusionadas na base, triangulares a arredondadas, ápice levemente agudo, margem hirsuta; ostíolo 2,8-5,7 mm diâm., geralmente proeminente, raro plano; orobrácteas 2, raramente 3, diminutamente pubescentes a geralmente glabras internamente, castanhoavermelhadas a alaranjadas, lineares; bractéolas 0,5-1,2 mm compr., 0,3-0,7 mm larg., triangulares a lanceoladas, alaranjadas a creme-avermelhadas. Flores estaminadas: pediceladas, (0,8-) 1,5-1,8(-2,2) mm compr., 0,6-1,0 mm larg.; tépalas 3, alaranjadas a 
creme-avermelhadas, glabras; estame 1. Flores pistiladas: pedicelos maiores (1,7-)2,84,0(-5,5) mm compr., pedicelos menores 0,5-2,3 mm compr., 0,8-1,7 mm larg.; tépalas 3, fusionadas na base, levemente lobadas; estigma 1, penicelado, às vezes bifurcado, alaranjado a avermelhado. Drupa subglobosa a oval, 1,2-2,3 mm compr., 0,8-1,8 mm larg., creme-amarelada a alaranjada; semente 1, ovóide, alaranjada.

Material examinado: Itambé do Mato Dentro, Distrito de Santana do Rio Preto (Cabeça de Boi), margem do córrego, próximo da Trilha da Peroba, 19²4’59.2”S 4325’46.5”W, M. F. Santos \& E.G.A. Martins 163, 25.VIII.2007, fl. (SPF); Imediações do Córrego Cipó, à meia altura da serra, 19²4'52.0"S 4325'52.8”W, M.F. Santos \& H. Serafim 283, 14.Ill.2008, fl. (SPF); Jaboticatubas, Serra do Cipó, estrada de acesso à Usina Coronel Américo Teixeira - UCAT, J. Semir et al. 4439, 5.IX.1973, fl., fr. (SP, UEC); Santana do Riacho, Serra do Cipó, ao longo da rodovia Lagoa Santa-Conceição do Mato Dentro: km 106, margem direita da rodovia, mata de encosta, E.G.A. Martins et al. 67, 13.Il.2007, fr., fl. (SPF); margem esquerda da rodovia, Camping Véu-da-Noiva, base da Serra do Cipó, E.G.A. Martins \& P.T. Sano 68, 13.II.2007, bt. (SPF); km 87,5, ao longo do Rio Cipó, A.M. Giulietti et al. CFSC 7373, 1.VII.1981, fl., fr. (SP, SPF); Parque Nacional da Serra do Cipó, trilha Cânion das Bandeirinhas, Ribeirão Mascates, E.G.A. Martins et al. 80, 14.II.2007, bt. (SPF); Parque Nacional da Serra do Cipó, entre a base da Serra e o Rio Cipó, A.P. Duarte, 6408, 26.X.1961 (RB); Santana do Riacho, estrada de acesso ao Pico do Breu, 1634'S 4254', 900 m alt., área de pastagem, beira da estrada, E.G.A. Martins et al. 46, 23.IX.2006, fl., fr. (SPF);

Material adicional: Minas Gerais, Matozinho e Lagoa Santa, Área de Proteção Ambiental Carste de Lagoa Santa, mata semidecídua, A.E. Brina \& L.V. Costa sn, 6.VI.1995, fl., fr. (BHCB 36349). São Paulo, Teodoro Sampaio, Parque Estadual Morro do Diabo, 2223'44.1"S 52ํㅜㄱ'53.7'W, 420 m alt., R.A.S. Pereira et al. 155, fl.(SPF, SPFR).

Ficus obtusifolia possui ampla distribuição geográfica, ocorre principalmente do sudeste brasileiro ao Brasil Central e Norte, estendendo-se à Bolívia, Peru, Equador, Colômbia, Venezuela, América Central - inclusive nas ilhas caribenhas, e sul do México (Little Jr et al., 1974; Berg \& Villavicencio, 2004). No Brasil há registros no Amazonas, Goiás, Maranhão, Mato Grosso, Mato Grosso do Sul, Minas Gerais, Pará, Piauí, Rondônia e São Paulo, habitando em florestas de galeria e florestas semidecidual de baixa altitude, em florestas úmidas da Amazônia e mais raramente nos campos cerrado do Brasil Central (Berg \& Villavicencio, 2004; Carauta, 1989; Mendonça-Souza, 2006). 
Na Serra do Cipó ocorre na orla e no interior de matas ciliares localizadas no Cânion das Bandeirinhas e do Ribeirão Mascate, situados dentro do Parque Nacional da Serra do Cipó. Ocorrem também indivíduos isolados em matas de encosta, próximas ao Camping da Cachoeira Véu-da-Noiva e em áreas degradadas ocupadas por pastagens nas imediações do Pico do Breu. Embora F. obtusifolia não seja típica de substratos carbonáticos, foi coletada nas mediações da Usina Coronel Américo Teixeira - UCAT, em um ambiente caracterizado por solo calcário e areno-pedregoso.

F. obtusifolia apresenta lâmina obovada a levemente subobovada e base cuneada a obtusa. Essas características são semelhantes às de F. catappifolia Kunth \& C.D. Bouché, F. mattogrossensis Standl. e F. gardneriana (Miq.) Miq., o que levam geralmente a identificações imprecisas. No entanto Berg \& Villavicencio (2004) distinguem F. catappifolia de F. obtusifolia por apresentar pecíolo menor, base da lâmina levemente cordada e apenas duas orobrácteas visíveis. Quanto às outras duas espécies, Carauta (1989) considerou-as em senso amplo, sinonimizando-as e destacando aspectos do indumento do sicônio e do formato da base laminar como características que possam diferenciá-las. Assim fizeram Carauta \& Diaz (2002a) na publicação de 'Figueiras no Brasil' restabelecendo as duas espécies consideradas como sinônimos de F. obtusifolia pelos mesmos aspectos morfológicos destacados acima.

Berg \& Villavicencio (2004) propuseram novamente a sinonímia destas três espécies, considerando os materiais de espécimes brasileiras morfologicamente variáveis, cujas características incluíam F. mattogrossensis e F. gardneriana. Dessa forma, assim como verificado por Mendonça-Souza (2006) no estudo de Ficus do estado de São Paulo, os materiais da Serra do Cipó apresentam gradação das variações morfológicas referidas por Carauta (1989), Carauta \& Diaz (2002a) e Berg \& Villavicencio (2004). Assim adota-se aqui proposta de Berg \& Villavicencio (2004) de sinonímia e considera-se apenas F. obtusifolia ocorrente na Serra do Cipó. 
Figura 8. A. Dorstenia brasiliensis. A. Hábito. B-I. Ficus calyptroceras. B. Ramo com folhas e sicônios. C. Detalhe do indumento de tricomas na face abaxial da lâmina. D. Vista apical do sicônio. E. Vista basal do sicônio. G. Indumento de tricomas do sicônio. H. Flor pistilada de estilete longo. H. Flor pistilada de estilete curto. I. Semente. J-P. F. obtusifolia. J. Ramo com folhas e sicônios. K. Indumento de tricomas na base do sicônio. L. Vista apical do sicônio. M. Vista basal do sicônio. N. Corte longitudinal do sicônio. O. Indumento de tricomas do sicônio. P. Fruto. A: Simão et. al. CFCR 1744. B-E: Martins et al. 51. F-I: Martins et al. 108. K-P: Martins et al. 46 . 


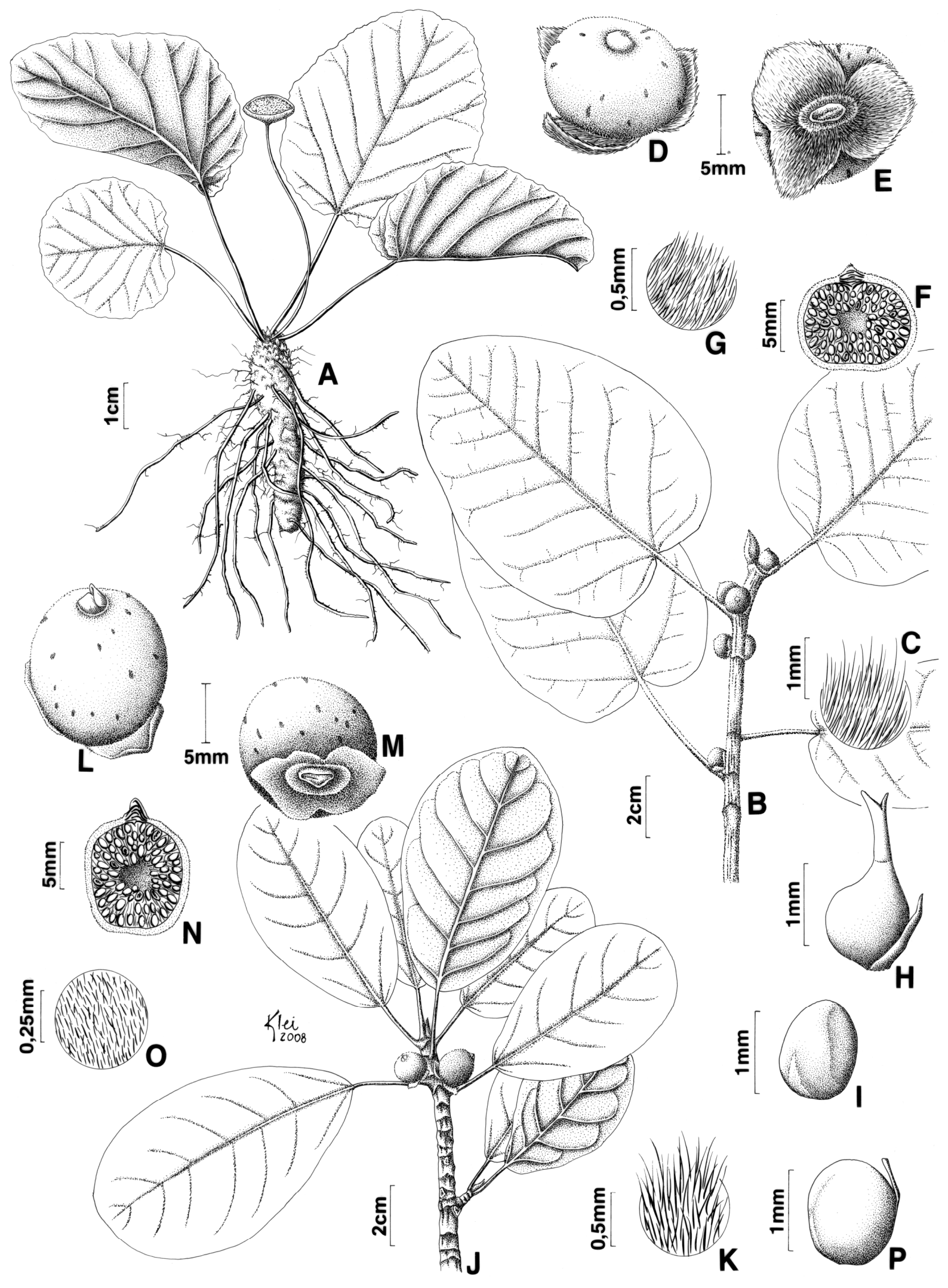


3.4. Ficus obtusiuscula (Miq.) Miq., Ann. Mus. Bot. Lugd-Bat. 3: 300. 1867

Nome vernacular. lombrigueira (GO e TO, Martins et al., 2007; Carauta, 1989; RJ, Carauta, 1996; Carauta \& Diaz, 2002a; SP, Mendonça-Souza, 2006); figueira, figueira-branca (SP, Mendonça-Souza, 2006).

Figura 9: I-Q.

Árvores, raramente hemiepífitas, 12,0-20,0 m alt.; raízes adventícias ausentes; ramos 3,0-8,5 mm larg., angulares a eretos, lisos, raramente canaliculados, glabros, esverdeados a castanho-acinzentados, periderme desprendendo-se, às vezes persistente. Lâmina foliar subcoriácea a cartácea, (7,0-)9,3-12,5(-14,0) cm compr., (3,55,0-6,7(-7, 5) cm larg., elíptica a oblonga, ápice agudo a curtamente acuminado, base aguda a cuneada, margem inteira, diminutamente revoluta; face adaxial glabra; face abaxial glabra, raramente pubescente sobre a nervura principal, 2 glândulas baselaminares presentes; venação broquidódroma, nervuras laterais 10-17 pares, ângulo distinto no $1^{\circ}$ par basal, proeminentes na face abaxial, venação terciária reticulada; pecíolo (2,0-)2,5-3,2(-4,5) cm compr., 0,2-0,4 mm larg., glabro, ferrugíneo a castanho-alaranjado, levemente canaliculado, periderme persistente; estípulas (1,52,0-2,7(-3,3) cm compr., glabras a diminutamente e esparsamente pubescentes, ferrugíneas a castanho-avermelhadas, glabras internamente, às vezes decíduas, rugosas. Sicônio, globoso, 0,5-0,8(-1,2) cm compr., 0,6-1,0(-1,3) cm larg., axilar, solitário, às vezes aos pares, acinzentado a castanho-alaranjado, máculas esverdeadas a enegrecidas; caliptra raramente presente; pedúnculo 2,0-3,5 mm compr.; epibrácteas 3, 0,7-1,5 mm compr., 1, 0-2,0 mm larg., diminutamente pubescentes, glabras internamente, ferrugíneas a castanho-alaranjadas, triangulares, separadas, às vezes fusionadas na base, arredondadas, ápice levemente agudo, margem glabra; ostíolo 1,0$1,5 \mathrm{~mm}$ diâm., proeminente; orobrácteas externas 5 , diminutamente pubescentes na base, castanho-avermelhadas; bractéolas 1,3-2,0(-2,5) mm compr., 0,2-0,5 mm larg., oblongas, alvas a creme-transparentes. Flores estaminadas: 1,4-2,3 mm compr., 0,41,5 mm larg.; tépalas 6, $2 \mathrm{em}$ forma de caliptra, ápice lobado, raramente fusionadas na base, alaranjadas a castanho-avermelhadas, glabras a diminutamente hispidulosas, pedicelo curto; estames 3 . Flores pistiladas: tépalas 6 , triangulares ou lanceoladas, livres, alaranjadas a castanho-avermelhadas; estigma 1, simples, reto; flores 
pediceladas: pedicelo curto e espesso, 2,0-3,5(-4,5) mm compr., 1,0-2,0 estilete curto; flores sésseis: 1,0-2,5 mm compr., 0,8-1,6 mm larg., estilete longo. Drupa globosa, (1,6)2,5-3,8(-5,0) mm compr., 1,0-02,5 mm larg., creme-amarelada a alaranjada; semente 1, plana a levemente ovóide, creme-alaranjada.

Material examinado: Itambé do Mato Dentro, distrito de Santana do Rio Preto (Cabeça

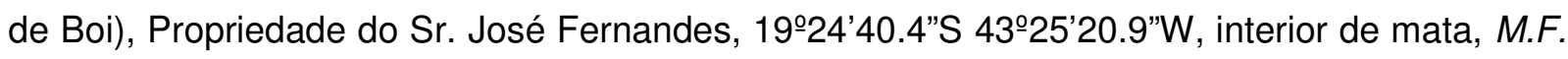
Santos \& H. Serafim 543, 16.V.2007, st. (SPF); Santana do Riacho, Serra do Cipó, arredores da Usina Coronel Américo Teixeira - UCAT, Riachinho, mata ciliar, M.A. Lopes \& P.M. Andrade s.n., 24.II.1985, fl., fr. (BHCB 8907); mata ciliar, P.M. Andrade \& M.A. Lopes s.n., 14.IV.1985, fl. (BHCB 9126).

Material adicional: Rio de Janeiro, Rio de Janeiro, Silva Jardim, Reserva Biológica Poço

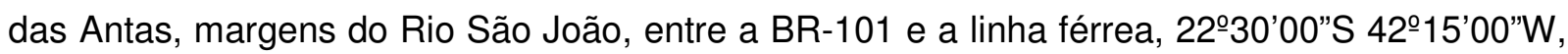
M. Peron et al. 968, 30.Xl.1992, fl., fr. (RB, SPF). São Paulo, Jardinópolis, margem do Rio Pardo, rodovia Anhanguera (SP-330 - sentido Ribeirão Preto - Jardinópolis) sobre o Rio Pardo:

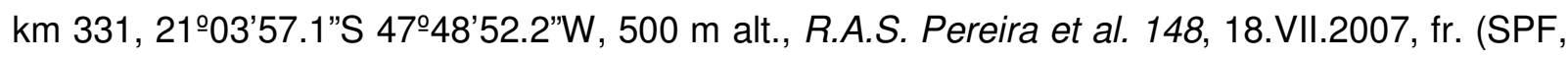
SPFR)

Ficus obtusiuscula (Miq.) Miq. apresenta distribuição da Amazônia central ao Paraguai e norte da Argentina, habitando principalmente ambientes úmidos. No Brasil ocorre no Amazonas, Bahia, Espírito Santo, Goiás, Maranhão, Mato Grosso, Mato Grosso do Sul, Minas Gerais, Pará, Piauí, Paraná, Rio de Janeiro, Rondônia, São Paulo, Tocantins e no Distrito Federal, principalmente em floresta atlântica, em matas ciliares inclusas no domínio do cerrado, sempre em baixas altitudes. Na Serra do Cipó ocorre unicamente nas matas ciliares dos córregos e riachos que abastecem o reservatório aquático da Usina Coronel Américo Teixeira - UCAT.

Entre as demais espécies do gênero na Serra do Cipó, Ficus obtusiuscula pode ser facilmente identificada pela presença de nervuras secundárias paralelas, duas glândulas baselaminares, sicônios geralmente solitários e flores com três estames. Trata-se da única espécie do subgênero Pharmacosycea, caracterizado pelos 3 estames, ocorrente na Serra do Cipó. 
Ficus obtusiuscula é considerada como uma espécie próxima da ameaça de extinção na flora de Goiás e Tocantins (Martins et al., 2007) e apresenta ocorrência rara para o estado de São Paulo (Mendonça-Souza, 2006).

Essa espécie provavelmente é estreitamente relacionada com $F$. insipida Willd., com a qual pode ser confundida, mas diferenciando-se desta por apresentar sicônios, estípulas e folhas menores e com formatos diferentes, assim como habitar preferencialmente ambientes úmidos, enquanto $F$. insipida habita diversos ambientes. Além disso, os estudos sobre anatomia foliar realizados por Melo-Filho (1963) e Leitão (1984) corroboram sua distinção como duas espécies. 
3.5. Ficus pertusa L.f., Suppl. PI. 442. 1782, non Bory ex. Miq. 1847.

Nome vernacular: uapuim-açu (RJ, Carauta, 1996; Carauta, 1989; Carauta \& Diaz, 2002a; GO, Martins et al., 2007); figueira d'água (SP, Crestana et al., 2006); atraca-da-folha-miúda, apuí, gameleira-da-folha-miúda (SP, Mendonça-Souza, 2006); gameleira, figueira, mata-pau (MG, E. Tameirão-Neto 1922, BHCB 33398)

Figura 9: $\mathrm{R}-\mathrm{X}$.

Árvores, às vezes hemiepífitas, 4,0 a 10,0 m alt.; raízes adventícias presentes; ramos $0,3-0,7 \mathrm{~cm}$ larg., tortuosos a levemente eretos, rugosos a canaliculados, glabros, raramente pubescentes, castanho-acinzentados a avermelhados, periderme persistente, às vezes desprendendo-se. Lâmina foliar coriácea a subcoriácea, (3,0-)5,37,5(-9,5) cm compr., (1,3-)2,2-3,5(-4,5) cm larg., ovada a subobovada ou elíptica, ápice acuminado a agudo, às vezes levemente arredondado, base cuneada a atenuada ou levemente aguda, margem inteira, levemente revoluta; face adaxial geralmente glabra, lisa a levemente áspera ao toque; face abaxial glabra, às vezes diminutamente e esparsamente pubescente sobre a nervura principal, lisa a áspera ao toque, glândula acropeciolar presente; venação broquidódroma, nervuras laterais 6-10(-11) pares, ângulo do par basal distinto, venação terciária reticulada; pecíolo $(0,8-) 1,7-2,8(-4,0) \mathrm{cm}$ compr., (0,5-)1,2-1,5(-2,0) mm larg., glabro, raramente pubescente, amareloesverdeado a castanho-avermelhado, levemente enegrecido na base, levemente canaliculado, periderme persistente, às vezes desprendendo-se na base; estípulas (0,30,8-1,2(-1,6) cm compr., geralmente glabras, às vezes diminutamente e esparsamente pubescentes, castanho-avermelhadas a vináceas, glabras internamente, às vezes decíduas, macia ao toque. Sicônio subgloboso a globoso ou elipsóide a obovóide, 1,22,3 cm compr., 0,4-0,8 cm larg., axilar, pedunculado (pedúnculo 0,3-0,8 cm compr.), geralmente aos pares, caliptra geralmente ausente, geralmente glabro, amareloesverdeado com máculas alaranjadas a marrom-avermelhadas; epibrácteas 2, 4,3-6,0 $\mathrm{mm}$ compr., 4,5-8,3 mm larg., densamente tomentosas externamente, glabras a seríceas internamente, brancas a levemente castanho-ferrugíneas, geralmente separadas, às vezes fusionadas na base, triangulares a arredondadas, ápice levemente agudo, margem hirsuta; ostíolo 2,8-5,7 mm diâm., geralmente proeminente, crateriforme, raro plano; orobrácteas 2 , às vezes 3 , diminutamente pubescentes a 
geralmente glabras internamente, castanho-avermelhadas a alaranjadas; bractéolas 0,3-1,0 mm compr., 0,2-0,7 mm larg., triangulares a lanceoladas, alaranjadas a cremetransparentes. Flores estaminadas: pediceladas, (0,8-)1,5-1,8(-2,2) mm compr., 0,6-1,0 $\mathrm{mm}$ larg.; tépalas 3, alaranjadas a creme-avermelhadas, glabras; estame 1. Flores pistiladas: tépalas 3 , em forma de caliptra, raramente fusionadas na base, alaranjada a castanho-avermelhadas; estigma 1, plumoso, retos ou decurrentes; flores pediceladas: pedicelo curto e espesso, (0,5-)0,8-1,5 (-2,1) mm compr., 0,4-1,5, estilete curto; flores sésseis: 0,8-2,8 mm compr., 0,3-1,4 mm larg., estilete longo. Drupa globosa a oval, 0,41,0 mm compr., 0,3-0,8 mm larg., creme-amarelada a alaranjada; semente 1, ovóide, creme-alaranjada.

Material examinado: Conceição do Mato Dentro, rodovia Belo Horizonte - Conceição do Mato Dentro, ponte sobre o Rio Santo Antônio, 190.'23.5"S 4326 '43.2"W, 606 m alt., mata ciliar, E.G.A. Martins et al. 57, 19.1.2007, bt. (SPF); Santana do Riacho, ao longo da rodovia Belo Horizonte - Conceição do Mato Dentro, córrego Mãe d'Água, J.R. Pirani et al. CFSC 7597, 8.X.1981, fl. fr. (SP, SPF).

Material adicional: Minas Gerais, Gurinhatã, BR-364, área de transição entre Cerradão e Floresta Estacional Semidecidual, 19¹9'40.5”S 4949'35.5”W, $542 \mathrm{~m}$ alt., L.F.M. Coelho et al. 9, 24.V.2007, fl., fr. (SPF, SPFR).

Ficus pertusa L.f. apresenta distribuição predominantemente tropical, embora ocorra em regiões subtropicais. Ocorre do sul do México e América Central (inclusive Antilhas) à América do Sul - Peru, Bolívia, Paraguai e Brasil, habitando florestas úmidas, semidecidual a decidual em altitudes até $2000 \mathrm{~m}$. No Brasil ocorre no Acre, Amazônia, Amapá, Bahia, Espírito Santo, Goiás, Maranhão, Mato Grosso, Mato Grosso do Sul, Minas Gerais, Pará, Paraná, Pernambuco, Rio Grande do Sul, Rio de Janeiro, Rondônia, Santa Catarina, São Paulo e Distrito Federal (Berg \& Villavicencio, 2004; Carauta, 1989; Carauta e Diaz, 2002a). Na Serra do Cipó ocorre na margem do Rio Santo Antônio e no vale do Córrego Mãe d'Água.

Ficus pertusa é reconhecida pelas folhas pequenas, glabras, sicônios curtamente pedunculados com o ostíolo geralmente crateriforme rodeado por um anel circular bem visível. Carauta (1989) verificou ser essa espécie muito confundida com $F$. perforata L., a qual difere principalmente pelo ostíolo frequentemente plano. Além desse, há 
problemas de circunscrição específica também com os binômios $F$. arpazusa Casar., $F$. citrifolia Mill. e F. guaranitica Chodat (Carauta, 1989; Berg et al., 1984; Berg \& Villavicencio, 2004; Mendonça-Souza, 2006). Carauta (1989) em estudo de Ficus do Brasil considerou apenas $F$. pertusa e mais duas espécies, colocando $F$. arpazusa como sinônimo de F. citrifolia. Já Berg \& Villavicencio (2004) preferem tratar F. arpazusa como sinônimo de F. pertusa L.f.

Com efeito, Ficus pertusa é um complexo muito variável, praticamente em consenso amplo por vários autores (Berg \& Simonis, 1981; Carauta, 1989; Berg, 1989; Berg \& Villavicencio, 2004; Mendonça-Souza, 2006). Berg \& Simonis (1981), em um amplo estudo sobre Ficus, agruparam as espécies em complexos, onde um destes é denominado como 'Ficus pertusa complex'. Berg \& Villavicencio (2004) em continuidade aos estudos de complexos de Ficus, nomeia três formas para os materiais brasileiros de F. pertusa: 'arpazusa-form' - materiais procedentes do leste brasileiro (Bahia, Espírito Santo, leste de Minas Gerais, Paraná, Rio de Janeiro, Rio Grande do Sul, São Paulo e Santa Catarina), apresentando sicônios médios a grandes (cerca de 1-1,5 cm diâm.), com ostíolo geralmente crateriforme; 'padifolia-form' - materiais dotados de sicônios amplos e ostíolo não crateriforme, ocorrentes na Amazônia extra-brasileira e em toda a América do Sul e Central e, por último, 'subtriplinervia-form' - espécimes provenientes de áreas de Goiás e do oeste de Minas Gerais, apresentando sicônios pequenos (aproximadamente 0,3-0,8 cm diâm.) e maculados, com pedúnculo curto.

Mendonça-Souza (2006) no tratamento taxonômico de Ficus para a flora de São Paulo adotou o conceito de Carauta (1989) e manteve as três espécies distintas por meio das seguintes características: $F$. pertusa diferenciado por apresentar folhas de base e ápice agudos; F. guaranitica diferencia-se das demais por apresentar sicônio piriforme com ostíolo plano, folha de base cordada e ápice acuminado, e F. citrifolia com sicônio globoso e ostíolo crateriforme maiores que os de $F$. pertusa, folhas de base truncada e ápice longo acuminado.

Segundo Crestana et al. (2006), no estado de São Paulo, F. pertusa é uma espécie que tolera certa umidade do solo assim como períodos de seca, habitando principalmente em floresta ombrófila densa, floresta estacional e mata ciliar; frutifica de agosto a março e chega a produzir 3.000 .000 sementes por quilograma. 
A madeira de $F$. pertusa é frequentemente utilizada para a de lenha e carvão, tendo em vista sua baixa densidade, e seus frutos são geralmente utilizados para alimentação de pássaros e mastofauna (Crestana et al., 2006).

Figura 9. A-H. Ficus gomelleira. A. Ramo com folhas e sicônios. B. Detalhe da face abaxial da lâmina, mostrando a glândula acropeciolar. C. Vista apical do sicônio. D. Vista basal do sicônio. F. Corte longitudinal do sicônio. G. Flor pistilada de estilete longo. H. Flor pistilada de estilete curto. I-Q. F. obtusiuscula. I. Folha. J. Detalhe do indumento de tricomas da face abaxial da lâmina. K. Detalhe da face abaxial da lâmina, mostrando as glândulas baselaminares. L. Vista apical do sicônio. M. Vista basal do sicônio. N. Corte longitudinal do sicônio. O. Flor estaminada. P. Flor pistilada de estilete curto. R-X. F. pertusa. R. Ramo com folhas e sicônios. S. Detalhe da estípula. T. Vista apical do sicônio. U. Vista basal do sicônio. V. Corte longitudinal do sicônio. W. Flor pistilada de estilete longo. X. Flor pistilada de estilete curto. A-H: Santos \& Martins 162. I-Q: Lopes \& Andrade BHCB 9126. R-X: Pirani et al. CFSC 7597. 


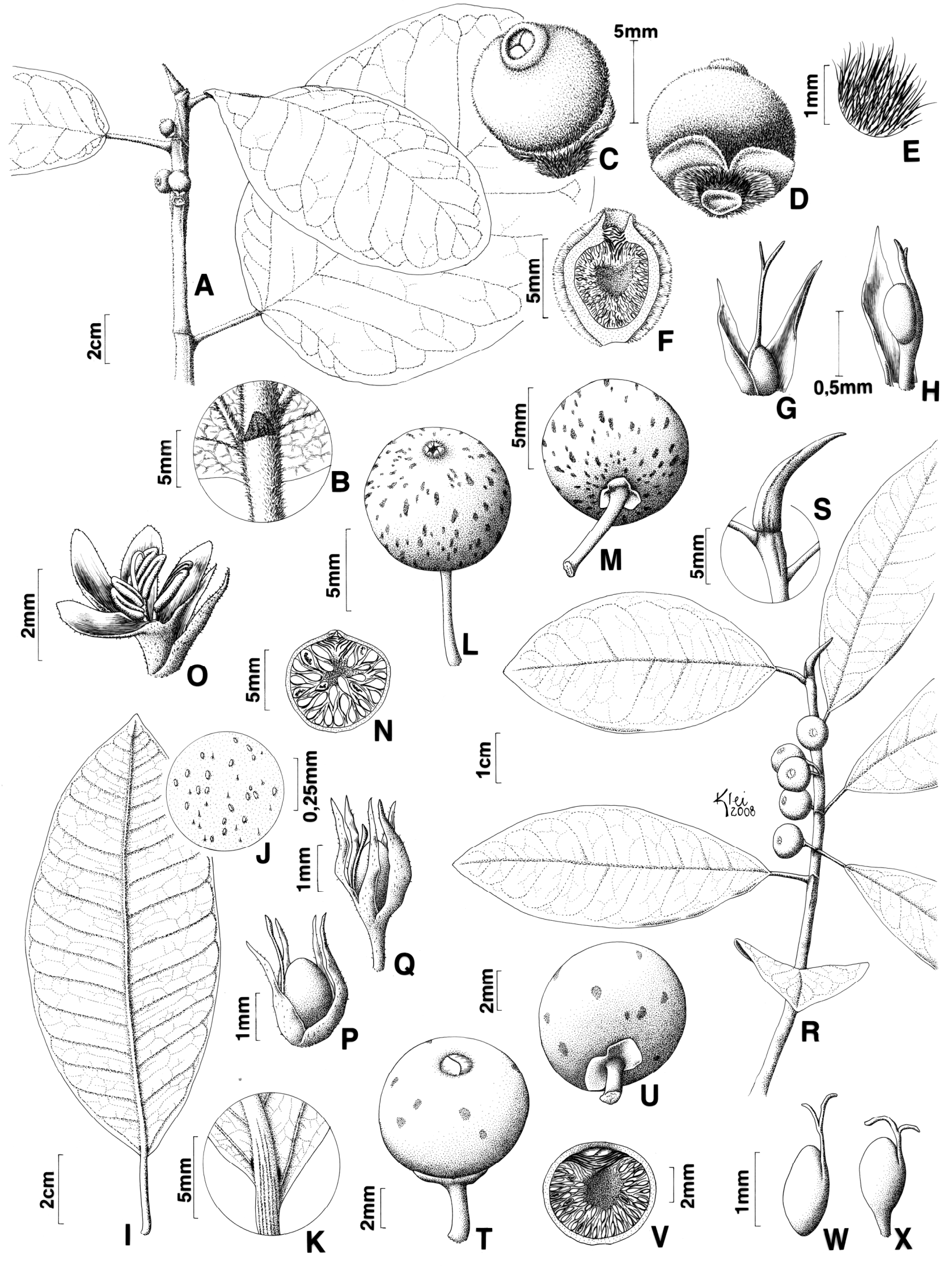




\section{Helicostylis Tréc.}

Árvores até $12 \mathrm{~m}$ alt., latescente, ramos monopodiais. Folhas simples, alternas, dísticas; lâmina inteira, margem inteira, frequentemente amarronzada quando seca, geralmente pubescente, tricomas globosos ou oblongo-capitados; venação broquidódroma; pecíolo levemente canaliculado, tomentoso a pubescente; estípulas pequenas, livres, semi-amplexicaules, decíduas. Inflorescências unissexuadas (plantas monóicas ou dióicas), unifloras, brácteas interflorais ausentes; inflorescências estaminadas geralmente axilares, discóides, pedunculadas, fasciculadas, às vezes aos pares, receptáculo revoluto quando jovem; flores: tépalas (3-)4, lobadas ou partidas, geralmente livres, às vezes conatas na base; estames (2-)4, 2 verticilos frequentemente assimétricos, filetes retos no botão, alongados, conectivos estreitos ou amplos; pistilódio raramente presente; inflorescências pistiladas axilares, solitárias, às vezes aos pares, sésseis ou pedunculadas; flores: tépalas 4, lobadas a partidas, às vezes livres; ovário levemente livre, às vezes adnato lateralmente à base do perianto; estilete espiralado; estigmas 2, filiformes, retos ou curvos. Fruto livre, às vezes adnato ao perianto expandido, amarelado a esverdeado, endocarpo levemente crustáceo; sementes geralmente grandes.

O gênero compreende sete espécies distribuídas pela América Central e Sul (Berg \& Simonis, 2000; Berg, 1972; 2001; Carauta, 1996), ocorrendo principalmente desde a Costa Rica, Panamá, Venezuela, leste do Peru, Bolívia, Equador, Colômbia e leste brasileiro. Na Serra do Cipó, assim como em todo o estado de Minas Gerais, ocorre apenas H. tomentosa (Poepp. \& Endl.) Rusby, habitando no domínio atlântico, principalmente em floresta estacional semidecidual de terras baixas e montanas.

Embora Helicostylis Tréc. e Maquira Aubl. tenham sido considerado congêneres por muito tempo (Berg, 1972), são atualmente bem caracterizados pela disposição das tépalas na flor pistilada. O nome Helicostylis origina-se das palavras gregas helix = volta e stylos = estilete, em alusão ao seu estilete espiralado ou helicoidal. 
4.1. Helicostylis tomentosa (Poepp. \& Endl.) Rusby, Mem. Torrey Bot. Club 6: 120. 1896.

Nome vernacular: inharé-folha-peluda, inharé-paina (AM, Ribeiro \& Berg, 1999); mão-de-gato (AM, RJ, Carauta et al., 1996); pau-de-letras (RJ, Carauta, 1996).

Figura 11: A - E.

Árvores até $15,0 \mathrm{~m}$ alt.; ramos foliares, 0,3-0,8 cm larg., amarelos a amarronzados, pubescentes a tomentosos, às vezes hirtelos; látex amarelado. Lâmina foliar cartácea a coriácea, (3,0-)7,5-15,0(-28,0) cm compr., (2,0-)3,3-8,0(-10,3) cm larg., elíptica a oblonga ou lanceolada, mais ampla próxima ao ápice, assimétricas, ápice acuminado a mucronado, às vezes agudo, base aguda a obtusa ou truncada a emarginada, margem geralmente inteira, às vezes denticulada próxima ao ápice; face adaxial esparsamente hirsuta a glabra, levemente pubescente sobre a nervura principal; face abaxial densamente tomentosa a pubescente, às vezes levemente hirtela; venação broquidódroma, impressas na face adaxial, proeminentes na face abaxial, nervuras laterais 8-16 pares, nervuras terciárias reticuladas a escalariforme; pecíolo 0,4-1,2 cm compr., tomentoso; estípulas $0,3-1,0 \mathrm{~cm}$ compr., tomentosas a levemente seríceas. Inflorescências estaminadas várias, geralmente 12, 2,0-7,5 mm diâm.; pedúnculo 2,010,0 mm compr., pubescente a tomentoso; brácteas involucrais presentes, geralmente em 4 verticilos; flores: tépalas lobadas a partidas, 0,6-1,5 mm compr., densamente pubescentes próximo ao ápice; estames 4, filetes 0,8-3,0 mm compr., externos mais curtos que os internos; anteras 0,2-0,7 mm compr., 0,2-0,4 mm larg., apiculadas ou não, conectivos estreitos ou amplos; estaminódios raramente presentes; inflorescências pistiladas geralmente solitárias, às vezes envoltas por 1-2 inflorescências estaminadas, pedunculadas, 3,5-6,5 mm diâm., hemisféricas a subglobosas; pedúnculo 4,0-8,0 mm compr., pubescente a tomentoso; brácteas presentes, geralmente ovadas a agudas, levemente pubescentes; flores: tépalas partidas, 1,0-1,8 mm compr.; estilete 0,5-1,3 $\mathrm{mm}$ compr., lateral, levemente piloso próximo ao ápice; estigma filiforme, 1,5-3,8 mm compr., levemente curvo. Infrutescências 1,5-4,8 cm diâm., subglobosas a globosas; perianto expandido, amarelado a amarronzado, levemente tomentoso; fruto $0,4-0,6 \mathrm{~cm}$ compr., 0,3 cm larg., semente pequena. 
Material examinado: Minas Gerais, Itambé do Mato dentro, Distrito de Santana do Rio Preto (Cabeça de Boi), Fazenda José Agostinho, 19²3'46.9"S 4324'07.4"W, M.F. Santos \& H. Serafim 336, 16.III.2008, fl., fr. (SPF); M.F. Santos \& L.M. Borges 538, 15.XII.2007, fl., fr. (SPF); M.F. Santos \& L.M. Borges 620, 15.XII.2008, fl., fr. (SPF); M.F. Santos \& L.M. Borges 540, 15.XII.2007, fl., fr. (SPF).

Material adicional: Bahia, Ilhéus, Rodovia Ilhéus-Itacaré (BA 001), km 20, acesso ao Retiro e para a Lagoa Encantada, 1435'10"S 397'2”W, $170 \mathrm{~m}$ alt., P. Fiaschi et al. 2676, 27.XI.2004, fl. (CEPEC, SPF); Uruçuca, estrada de Serra Grande para Uruçuca, Mata da Torre do Celular, 1429'59”S 396'54”W, 380 m alt., P. Fiaschi et al. 2054, 18.III.2004, fl., fr. (CEPEC, SPF); Valença, estrada de Valença para Guaibim, RPPN Água Branca, 1319'44"S 395'25"W, $220 \mathrm{~m}$ alt., P. Fiaschi et al. 2142, 28.III.2004, fr. (CEPEC, SPF).

Helicostylis tomentosa (Poepp. \& Endl.) Rosby apresenta distribuição desde a Venezuela ao oeste andino e litoral brasileiro, nas proximidades do estado do Rio de Janeiro, habitando principalmente em florestas úmidas acima de $1600 \mathrm{~m}$ alt. (Berg, 1972; Carauta, 1996). No Brasil ocorre no Amazonas, Bahia, Espírito Santo, Mato Grosso, Minas Gerais, Rio de Janeiro, Rondônia, Roraima e no Distrito Federal. Em Minas Gerais, essa espécie é considerada muito rara, encontrada principalmente no domínio atlântico nos Vales do Rio Doce e do Paraíba do Sul, em florestas do tipo estacional semidecidual das terras baixas e montanas e baixo-montana (Oliveira Filho, 2006; Stevens, 2008). Na Serra do Cipó ocorre um único indivíduo habitando na floresta estacional semidecidual da face leste da serra, florescendo e frutificando em março, agosto, novembro e dezembro.

Helicostylis tomentosa é muito variável em vários caracteres, especialmente no indumento dos ramos e folhas, que podem ser pubérulos, tomentosos ou hirtelos, variando a densidade do indumento de esparsa a densa na face abaxial das folhas. São encontradas situações intermediárias entre todos esses tipos de indumento, e o mesmo se verifica nas várias formas de folhas observadas na espécie, havendo uma aparente relação dessas variações com a idade da planta (Berg, 1972). As inflorescências pistiladas são sésseis ou frequentemente distintamente pedunculadas, e a dimensão e forma dos estames são também muito diversas. Ainda segundo Berg (1972) a maioria das coleções de uma região costumam ser muito similares, mas podem ser também 
muito diferentes entre si, e o padrão de variação desses vários caracteres, como o indumento e o comprimento do pedúnculo das inflorescências pistiladas, é reticulado.

\section{Maclura Nutt.}

Árvores ou arbustos, até $10 \mathrm{~m}$ alt., às vezes escandentes, geralmente armados; látex levemente amarelado. Folhas simples, alternas, dísticas ou espiraladas; lâmina inteira a levemente lobada, margem serreada a denteada; venação broquidódroma; pecíolo plano, levemente pubescente a glabro; estípulas livres ou conatas, laterais, semi-amplexicaules. Inflorescências unissexuadas (plantas dióicas), axilares, geralmente multifloras, bracteadas, glândulas amareladas a esverdeadas presentes, imersas nas brácteas e no perianto expandido; inflorescências estaminadas racemosas, globoso-capitadas ou espiciformes; flores: sésseis ou pedunculadas; tépalas (3-)4, livres ou conatas, decussadas ou imbricadas; estames 4, curvos no botão; pistilódio presente, oblongo, plano; inflorescências pistiladas globoso-capitadas; flores: tépalas 4, lobadas ou partidas, tubulares, decussadas; ovário livre, estigmas (1-)2, assimétricos, filiformes. Fruto composto e policárpico, drupáceo, perianto expandido, carnoso, esverdeado, endocarpo crustáceo; semente pequena, endosperma presente.

Maclura é composto por 11 espécies com distribuição exclusivamente tropical. Três espécies ocorrem na América desde os Estados Unidos até a Argentina, duas destas com ampla distribuição neotropical: M. tinctoria (L.) D. Don ex Steud. e M. brasiliensis (Mart.) Endl., sendo que a primeira espécie apresenta aproximadamente 80 sinônimos (Berg \& Simonis, 2000; Carvalho, 2003; Lachance et al., 2001).

No Brasil, essas duas espécies ocorrem desde a região amazônica até o sul do país habitando principalmente na orla de formações secundárias e matas abertas sobre solos úmidos de planícies aluviais (Mariano et al., 1998; Durigan \& Nogueira, 1990). De 
acordo com as características sucessionais é classificada como pioneira (Durigan \& Nogueira, 1990) ou clímax exigente de luz (Toniato \& Oliveira Filho, 2004). Na Serra do Cipó ocorre apenas M. tinctoria.

5.1. Maclura tinctoria (L.) D. Don ex Steud., Nomencl. Bot. (ed. 2) 2: 87. 1841.

Nome vernacular: taiúva, taiuveira, tatá-iva, amoreira-brava (SP, Kuhlmann \& Kühn, 1947; Crestana et al., 2006); amoreira, amora-do-mato (MS, Battilani et al., 2006); tatajuba, moreira (GO e TO, Martins et al., 2007; RJ, Carauta, 1996); apé, tatajuva (RJ, Carauta, 1996); taúba, tajuba, amora-branca, tatané, jataíba, pau-de-fogo (Lorenzi et al., 2006)

Figura 11: $\mathrm{F}-\mathrm{I}$.

Árvores ou arbustos, até 6,0 m alt., eretas, raízes tabulares às vezes presentes, ramos armados ou inermes, em 'zig-zag', glabros a levemente pubescentes; espinhos axilares, solitários ou aos pares, eretos; pequenas estípulas geralmente presentes, triangulares. Lâmina foliar membranácea a cartácea, $(2,0-) 3,7-8,5(-13,0) \mathrm{cm}$ compr., $(1,2-) 2,5-4,0(-5,5) \mathrm{cm}$ larg., elíptica a oblonga, raramente lanceolada a obovada, levemente assimétrica, ápice agudo a acuminado, às vezes caudado, base obtusa a arredondada ou cordada, margem lobada ou denteada a serreada; face adaxial esparsamente hirsuta; face abaxial glabra a esparsamente hirsuta, tomentosa a hirsuta sobre as nervuras; venação semicraspedódroma a broquidódroma, nervuras impressas na face adaxial, levemente proeminentes a impressas na face abaxial, nervuras laterais 6-12 pares, nervuras terciárias geralmente ausentes; pecíolo 0,2-1,0(-1,8) cm compr., levemente hirsuto a tomentoso; estípulas 0,2-0,7 cm compr., levemente pubescentes, pontiagudas. Inflorescências estaminadas racemosas, 2,0-9,5 cm compr., axilares, espigadas ou espiciformes, geralmente solitárias, pedunculadas, levemente amareladas; pedúnculo 0,3-1,2 cm compr., densamente pubescente a tomentoso; flores: tépalas 3-4, 0,4-1,2 mm compr., livres a conduplicadas, sésseis, entremeadas por brácteas glandulares, densamente pubescentes; estames 4, curvos no botão, filete 1,5-2,3 mm compr., anteras 0,2-0,6 mm compr., 0,3-0,7 mm larg.; pistilódio 0,2-0,7 mm compr., plano, membranoso, apiculado; inflorescências pistiladas subglobosas a capitadas, 0,2-0,5 cm diâm., axilares, geralmente solitárias, pedunculadas, 
esverdeadas; pedúnculo 0,3-1,5 cm compr., pubescente a levemente tomentoso; flores: tépalas 4, 0,6-1,0 mm compr., livres a levemente conatas, sésseis, decussadas, cuculadas, densamente pubescentes próximo ao ápice; ovário 0,3-0,8 mm compr., estilete 2,5-5,0 mm compr., filiforme, persistente no fruto, estigma indiviso, densamente pubescente; brácteas interflorais presentes, 0,6-1,0 mm compr., cuculadas, glândulas presentes próxima ao ápice. Fruto policárpico, composto de várias núculas comprimidas, 0,7-1,5 cm compr., 0,5-1,3 cm larg., globoso a oblongo ou elipsóide, amarelo-esverdeado na maturação, levemente carnoso, indeiscente, com aroma adocicado; semente achatada lateralmente, oval, lisa.

Material examinado: Minas Gerais, Itambé do Mato Dentro, distrito de Santana do Rio Preto (Cabeça de Boi), Fazenda José Agostinho, 19²4'04.1'S 4324'02.37'W, M.F. Santos \& E.G.A. Martins 177, 26.VIII.2007, fl., fr. (SPF); Propriedades do Nem, 19²4'03.5"S 43024'08.5’W, M.F. Santos \& H. Serafim 114, 13.Il.2007, fl. (SPF); Estrada das Posses, após a Fazenda José Agostinho, em direção à Mata do cachoeirão, 1925'54.7"S 43ำ5'58.3”W, M.F. Santos \& L.M. Borges 204, 18.VII.2007, fl., fr. (SPF).

Material adicional: Minas Gerais, Descoberto, Reserva Biológica da Represa do Grama, R.M. Castro et al. 875, 30.I.2004, fl., fr. (CESJ, SPF); Matozinhos, APA Carste de Lagoa Santa, Fazenda Caucaia, mata semidecídua, A.E. Brina \& L.V. Costa s.n., 2.IIl.1996, fl., fr. (BHCB 36346). Paraná, Londrina, Fazenda Figueira-Paiquerê, 2332'27"S 5058'32"W, M.C. Lovato et al. 182, 19.II.2003, fl., fr. (FUEL, SPF).

Maclura tinctoria (L.) D. Don ex Steud. apresenta ampla distribuição Neotropical, ocorrendo desde o sul do México à Argentina. No Brasil é encontrada no Acre, Amazonas, Bahia, Ceará, Espírito Santo, Goiás, Maranhão, Mato Grosso do Sul, Minas Gerais, Pará, Pernambuco, Piauí, Paraná, Rio de Janeiro. Rondônia, Rio Grande do Sul, Santa Catarina, São Paulo, Tocantins e no Distrito Federal, em formações secundárias e matas abertas (Carauta, 1996; Mariano et al., 1998; Martins et al., 2007). Na Serra do Cipó essa espécie ocorre em mata estacional semidecidual e ao longo da mata ciliar do Rio Preto, nas imediações da face leste da serra.

Em Minas Gerais, M. tinctoria é uma espécie comum ocorrendo tanto em regiões de domínio de Mata Atlântica (Vale do Jequitinhonha, Vale do Mucuri-Itanhém, Vale do Rio Doce, Vale do Paraíba do Sul, Alto do Rio Grande, Mantiqueira Sul e Planalto de 
Poços de Caldas) quanto no domínio do Cerrado (Espinhaço Sul, Noroeste e Triângulo) e em matas secas (Oliveira Filho, 2006).

Sua madeira é moderadamente flexível e durável, sendo empregada em serviços de movelaria, marcenaria e construções externas (Lorenzi, 2002; Paula \& Alves, 1997). O epíteto de $M$. tinctoria faz alusão à tinta amarela exsudada do caule e ramos, os quais apresentam propriedades medicinais muito utilizados como cicatrizante e antiflamatório (Pott \& Pott, 1994; Crestana et al., 2006).

Maclura tinctoria apresenta período curto de frutificação, porém produz, anualmente, grande quantidade de frutos na estação chuvosa, contribuindo com a oferta de recursos alimentares e amplo forrageamento durante esse período (Battilani et al., 2006). Em complemento, Ragusa-Neto (2002) observou que a presença de aves frugívoras/onívoras varia intensamente ao longo do ano, tendo maior abundância quando há oferta massiva de flores e dos frutos carnosos dessa espécie.

Battilani et al., (2006), em estudo sobre a morfologia dos frutos, sementes e desenvolvimento de plântulas e plantas jovens de $M$. tinctoria, verificaram que o pericarpo carnoso e doce e a coloração amarelo-esverdeada quando madura, indicam que esta espécie é amplamente consumida por vertebrados frugívoros, tornando-se importantes para a avifauna local. Devido às características biológicas de $M$. tinctoria e à sua importância ecológica para o forrageamento da fauna, Battilani et al. (2006) sugerem a utilização dessa espécie em modelos mistos de restauração ecológica, em sistemas agroflorestais e em plantios como poleiros naturais em áreas submetidas à regeneração natural.

$\mathrm{Na}$ Serra do Cipó, a espécie floresce de agosto a setembro e frutifica de novembro a janeiro. 


\section{Pseudolmedia Tréc.}

Árvores, até $13 \mathrm{~m}$ alt.; ramos lisos, branco a acinzentados, monopodiais, cicatrizes horizontais; látex amarelado, enegrecido quando exposto ao ar. Folhas simples, alternas, dísticas; lâmina geralmente inteira, margem geralmente inteira, densos tricomas pluricelulares, globoso-capitados, glândulas ausentes; pecíolo plano, glabro a levemente pubérulo; venação broquidódroma; estípulas livres, amplexicaules, decíduas. Inflorescências unissexuadas (plantas dióicas ou monóicas), geralmente axilares, discóide-capitadas, sésseis, unifloras, várias brácteas imbricadas, basifixas, cobrindo a superfície do receptáculo; inflorescências estaminadas sésseis, unifloras, discóides, livres; flores: perianto geralmente ausente, invólucro cobrindo os estames na antese; estames livres entremeados por brácteas dispostas concentricamente, filetes retos, anteras frequentemente apiculadas, ciliadas ou não; pistilódio geralmente ausente, às vezes reduzido; inflorescências pistiladas sésseis, unifloras; flores: tépalas 4, tubulares, denteadas, conatas; ovário completamente adnato ao perianto; estigma 2 , filiforme. Fruto drupáceo, perianto expandido na frutificação, avermelhado a alaranjado, carnoso ou suculento, endocarpo crustáceo; semente grande, endosperma ausente.

O gênero compreende nove espécies amplamente distribuídas pela América tropical, sendo seis destas pertencentes à sect. Pseudolmedia, restrita à América do Sul (Berg \& Simonis, 2000; Castro, 2006). Ocorre desde o sul do México, passando pelo Panamá, Venezuela, leste da Bolívia e Paraguai e norte da Argentina. No Brasil ocorre no Amazonas, Bahia, Maranhão, Mato Grosso, Mato Grosso do Sul, Minas Gerais, Piauí, Santa Catarina e São Paulo, habitando principalmente em áreas de cerrado. Em Minas Gerais há registros apenas de Pseudolmedia laevigata Tréc., no Espinhaço Sul, Noroeste e Triângulo Mineiro na orla ou interior de Floresta Estacional Semidecidual Alto Montana e em matas ciliares (Oliveira Filho, 2006). 
6.1. Pseudolmedia laevigata Trécul, Ann. Sci. Nat. Bot., Sér. 3, 8: 131. 1847.

Nome vernacular: marurê (RO, MT, MG, Carauta et al., 1996)

Figura 10: F - J.

Árvores, até 4,0 m alt.; ramos folhosos 1,0-3,2 mm larg., alvo-acinzentados a amarelados, glabros, às vezes levemente pubescentes; látex esbranquiçado, tornandose alaranjado. Lâmina foliar cartácea a coriácea, (2,5-)4,0-11,3(-14,5) cm compr., (1,52,5-3,5(-5,0) cm larg., elíptica a oblonga ou lanceolada, levemente assimétrica, ápice acuminado a agudo, base aguda a obtusa, às vezes emarginada, margem geralmente inteira, às vezes levemente sub-denteada; face adaxial geralmente glabra, diminutamente pubérula sobre a nervura principal; face abaxial glabra a esparsamente pubérula; venação broquidódroma, nervuras impressas na face adaxial, proeminentes na abaxial, nervuras secundárias 9-20 pares, nervuras terciárias reduzidas ou reticuladas; pecíolo 0,2-1,0 cm compr., glabro a levemente pubescente; estípulas 0,3$1,2 \mathrm{~cm}$ compr., esparsa a densamente pubescentes. Inflorescências estaminadas globosas a subglobosas, 0,2-0,7 cm diâm., 12-25 brácteas involucrais, reniformes, ovada a lanceoladas, esparsamente pubescentes, dispostas em 4-8 verticilos; flores: perianto geralmente ausente, muitas brácteas inter-estaminais, 1,0-3,2 mm compr., pubescentes a glabras externamente, dispostas concentricamente; estames 1-3, livres, filetes retos, 0,3-1,0 mm compr., anteras 0,7-1,0 mm compr., 0,2-0,4 mm larg., apiculadas ou não, ciliadas ou não, conectivo amplo; pistilódio geralmente ausente, às vezes reduzido. Inflorescências pistiladas 1,5-2,0 mm compr., isoladas; 8-15 brácteas involucrais, reniformes a ovadas, obtusas a agudas, esparsamente pubescentes, dispostos em 3-6 verticilos; flores: tépalas tubulares, 1,0-2,0 mm compr., esparsa a densamente pubescentes; ovário livre, pubescente, estilete 0,3-0,8 mm compr., estigmas 2, 2,0-5,7 mm compr., filiformes. Fruto amplo, envolto por perianto expandido, elipsóide, 6,5-8,5 mm compr., 4,3-5,2 mm larg., esparsamente pubescente, às vezes concentrado no ápice, alaranjado a avermelhado, carnoso a suculento; sementes 3,04,5 mm compr., 2,4-3,5 mm larg.

Material examinado: Santana do Riacho, ao longo da rodovia Belo Horizonte Conceição do Mato dentro, córrego Mãe D’Água, J.R. Pirani et al. CFSC 7598, 8.X.1981, fl., fr. (SPF); Serra do Cipó, rodovia Lagoa Santa - Conceição do Mato Dentro: km 106, margem 
direita da rodovia, próximo a cachoeira da "capelinha", mata de encosta, E.G.A. Martins et al. 66, 13.II.2007, bt. (SPF); Serra do Cipó, Parque Nacional da Serra do Cipó, trilha do Cânion das Bandeirinhas, margem direita, próximo ao paredão do Cânion, E.G.A. Martins \& P.T. Sano 75, 14.II.2007, bt. (SPF); Serra do Cipó, estrada para a Usina Dr. Pacífico Mascarenhas (ramal da rodovia Lagoa Santa - Conceição do Mato Dentro - MG 010), sobre o Ribeirão Indequicé, mata ciliar, E.G.A. Martins et al. 50, 17.I.2007, fr. (SPF).

Material adicional: Minas Gerais, São Gonçalo do Rio Preto, Parque Estadual do Rio

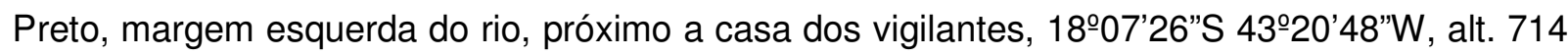
m, F.N. Costa \& L.G. Lessa 1038, 22.II.2006, fl., fr. (SPF).

Pseudolmedia laevigata Tréc. apresenta distribuição predominantemente tropical, desde o Panamá, Venezuela, Guiana Francesa, Equador, Colômbia, Peru, Paraguai ao Brasil. Neste, ocorre no Acre, Amazonas, Rondônia, Roraima, Bahia, Mato Grosso, Minas Gerais, São Paulo e no Distrito Federal, habitando principalmente em matas úmidas e cerradão ocorrentes acima de 1500 m alt. (Berg \& Simonis, 2000; Berg, 1972).

Na Serra do Cipó, $P$. laevigata Tréc. ocorre em matas de encosta e de galeria nas proximidades do Cânion das Bandeirinhas, situado dentro do PARNA Serra do Cipó, e na orla e interior das matas ciliares ao longo do Ribeirão Indequicé (ou Andrequicé).

Berg (1972) registrou a possibilidade de essa espécie florescer o ano todo, principalmente a partir de setembro a novembro. Entretanto, na Serra do Cipó foi coletada apenas com botões nos meses de janeiro e fevereiro e florescendo em outubro. Frutos foram achados em outubro e janeiro. 


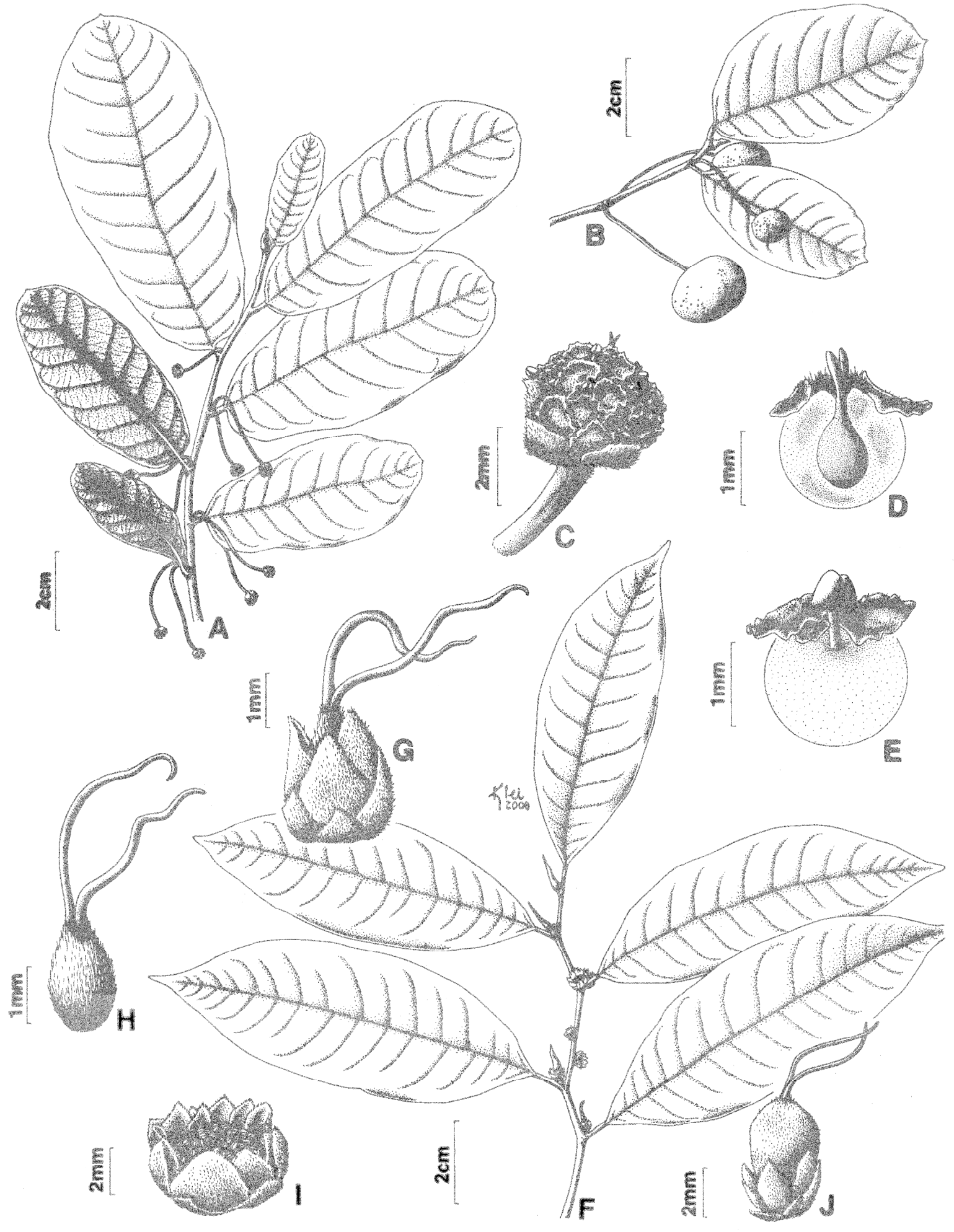

Figura10.A-E. Brosimum gaudichaudii . A. Ramo fértil. B. ramo frutífero. C. Inflorescência bissexuada. D. Flor pistilada. E. Flor estaminada. F-J. Pseudolmedia laevigata. Ramo fértil. G e H. Flor pistilada.

I. Inflorescência estaminada. J. Fruto. A, C-E: Lombardi \& Toledo 454. B: Yamamoto \& Freitas 67.

F-I: Martins 47. J: Kameyama CFSC 9465. 


\section{Sorocea A.St.-Hil.}

Árvores ou arbustos; ramos inermes, glabros a levemente pubescentes, lenticelas conspícuas frequentes. Folhas simples, alternas, dísticas; lâmina inteira, margem geralmente denteada a crenulada ou espinulada, glândulas ausentes; venação craspedódroma ou semicraspedódroma; pecíolo plano, geralmente glabro; estípula livre, lateral. Inflorescências unissexuadas (plantas dióicas), solitárias ou aos pares, axilares ou logo abaixo, multifloras; brácteas pequenas, basifixas ou peltadas, cordiformes, ovadas ou sub-orbiculares; inflorescências estaminadas racemos, espigas ou sub-capitadas; flores: tépalas 4 , decussadas, imbricadas, geralmente conatas; estames 2-4, livres, retos no botão, anteras basifixas, às vezes dorsifixas, extrorsas, conectivo amplo, frequentemente apiculado; pistilódio geralmente ausente; inflorescências pistiladas racemosas, às vezes sub-espigadas a sub-capitadas; flores: tépalas 4 , lobadas, às vezes levemente inteiras, tubulares, parte apical e basal distintas, parte basal adnata ao ovário; perianto expandido, pedicelo e pedúnculo carnosos, avermelhados a alaranjados na frutificação; estigma 2, simétricos, curtos. Fruto amplo, globoso a elipsóide, adnato ao perianto expandido; endocarpo coriáceo a subcrustáceo; semente grande, endosperma ausente, testa fina; cotilédones assimétricos.

O gênero Sorocea distribui-se por toda a região tropical e subtropical, com maior diversidade na América do Sul e Central (Romaniuc-Neto, 1996). O gênero compreende 14 espécies neotropicais, subdivididas em dois subgêneros: subg. Sorocea, com a maioria das espécies, e o subg. Paraclarisia que compreende somente duas espécies neotropicais (Berg \& Simonis, 2000). Na Serra do Cipó encontra-se apenas uma espécie, pertencente ao subg. Sorocea: S. guilleminiana Gaudch.

Berg \& Akkermans (1985) propuseram novos táxons e combinações de Sorocea, no qual 13 táxons foram reconhecidos para o Brasil, 10 destes concentrados na Bacia Amazônica e apenas $S$. bonplandii, $S$. guilleminiana e $S$. hilarii ocorrentes no sul e sudeste brasileiro. No entanto, Berger et al. (1962) registraram também S. racemosa ocorrendo na Mata Atlântica do sudeste brasileiro. 
Vários autores tem sugerido a necessidade de uma revisão das espécies do gênero ocorrentes no Brasil, principalmente das espécies da região oeste brasileiro (Romaniuc-Neto, 1996; Burger et al., 1962).

7.1. Sorocea guilleminiana Gaudichaud, Voy. Bonite, Bot. Atlas t. 74. 1844.

Nome vernacular: jaca-branca, jaca-brava (AM, Ribeiro \& Berg, 1999); bainhade-espada (RJ, Carauta, 1993); folha-de-serra, canela dourada (MG, Tameirão Neto 2654, BHCB 46493)

Figura 11: J $-\mathrm{K}$.

Árvores ou arbustos, até 10,0 m alt.; ramos folhosos 1,0-3,0 mm larg., glabros a esparsamente pubescentes, cicatrizes horizontais presentes. Lâmina foliar sub-coriácea a coriácea, (4,5-)10,5-17,3(-20,0) cm compr., (1,5-)4,3-6,8(-8,5) cm larg., elíptica a oblonga ou lanceolada, ápice acuminado, espinuloso, base aguda a obtusa, às vezes sub-cordada, margem geralmente espinulosa a denticulada, raramente inteira, revoluta; face adaxial glabra; face abaxial glabra a esparsamente subpubescente, levemente hirtela sobre a nervura principal; venação semicraspedódroma, impressa na face adaxial, proeminente na abaxial, nervuras laterais 9-15 pares, nervuras terciárias geralmente escalariforme; pecíolo $(0,2-) 0,5-1,0(-1,5) \mathrm{cm}$ compr., pubescente a glabro; estípula membranácea, 0,3-1,0 cm compr., diminutamente pubescentes, decíduas a sub-persistentes. Inflorescências estaminadas pêndulas, 1,5-5,0 cm compr., pedúnculo de 0,3-1,0 cm compr.; flores: tépalas partidas ou lobadas, esparsamente pubescentes, cilioladas, pediceladas; estames 2-4, livres, filetes 0,5-1,0 mm compr., anteras 0,2-0,8 mm compr., 0,2-0,5 mm larg., conectivo amplo. Inflorescências pistiladas patentes ou pêndulas, 1,7-5,5 cm compr., pedúnculo 0,3-1,5 cm compr., pubescente; flores: tépalas lobadas a inteiras, esparso-pubescentes a glabras externamente, face abaxial densamente pubescente a hispidulosa, às vezes glabras, pediceladas ou subsésseis; pedicelo 0,2-0,4 cm compr., 0,3-1,0 cm compr. na frutificação, estilete longo, estigma subulado, 0,2-0,5 mm compr., papilas presentes. Frutos 0,4-1,0 cm compr., 0,3-0,7 cm larg., perianto expandido, globoso a elipsóide ou ovóide, avermelhado a enegrecido, ápice arredondado, superfície lisa a verrucosa ou muricado. 
Material examinado: Itambé do Mato Dentro, distrito de Santana do Rio Preto (Cabeça de Boi), propriedades do José Agostinho, 1923'46.9"S 4324'07.4"W, M.F. Santos \& L.M. Borges 541, 15.II.2007, fr. (SPF); Córrego Cipó, à meia altura da serra, 19²4'52.0"S 4325’52.8”W, M.F. Santos \& E.G.A. Martins 170, 25.VIII.2007, st. (SPF); M.F. Santos \& H. Serafim 281, 14.III.2008, fl., fr. (SPF); Propriedades do Nem, 19²3'49.2"S 4324'05.8”W, M.F. Santos \& E.G.A. Martins 134, 23.VIII.2007, st. (SPF); Santana do Riacho, Serra do Cipó, APA Morro da Pedreira (afloramentos de calcários na base da Serra do Cipó), 19¹8’34.3"S 433'ㄷ‥'W, alt. $821 \mathrm{~m}$, mata decídua, E.G.A. Martins et al. 44, 24.IX.2006, bt. (SPF); ao longo da rodovia Belo Horizonte - Conceição do Mato Dentro: km 128, capão, R. Mello-Silva et al. CFSC 9775, 3.V.1986, fl. (SPF)

Material adicional: Minas Gerais, Descoberto, Reserva Biológica da Represa do Grama, F.R.G. Salimena s.n., 30.X.2000, fr. (CESJ 31437, SPF).

Sorocea guilleminiana Gaudch. é encontrada principalmente na América tropical, em regiões úmidas da Venezuela, Peru, Bolívia e Equador ao leste brasileiro. No Brasil ocorre desde a Amazônia - nos estados do Acre, Amazonas, Mato Grosso e Rondônia, passando pelo Brasil Central ao sudeste brasileiro, tido como área de maior concentração de suas populações (Carauta, 1993; Berg \& Simonis, 2000; RomaniucNeto, 1996).

$\mathrm{Na}$ Serra do Cipó ocorrem indivíduos isolados no interior de floresta decidual associada a solos carbonáticos e na orla e interior de floresta estacional semidecidual da face leste da serra, e também em capão de mata do alto da serra.

Floresce de agosto a outubro, com frutificação indo até março. 
Figura 11: A - E. Helicostylis tomentosa. A. Ramo fértil. B. Detalhe de Ramo frutífero. C. Flor pistilada. D. Flor estaminada. E. Vista ventral e dorsal do estame. F - I. Maclura tinctoria. F. Ramo fértil. G. Flor pistilada. H. Flor estaminada. I. Fruto. J - K. Sorocea guilleminiana. J. Ramo fértil. K. Fruto. A, D e E: Santos \& Borges 514. B: Santos \& Serafim 336. C: Santos \& Borges 540. F e H: Santos \& Martins 177. G e I: Santos \& Borges 204. J e K: Santos \& Borges 541. 


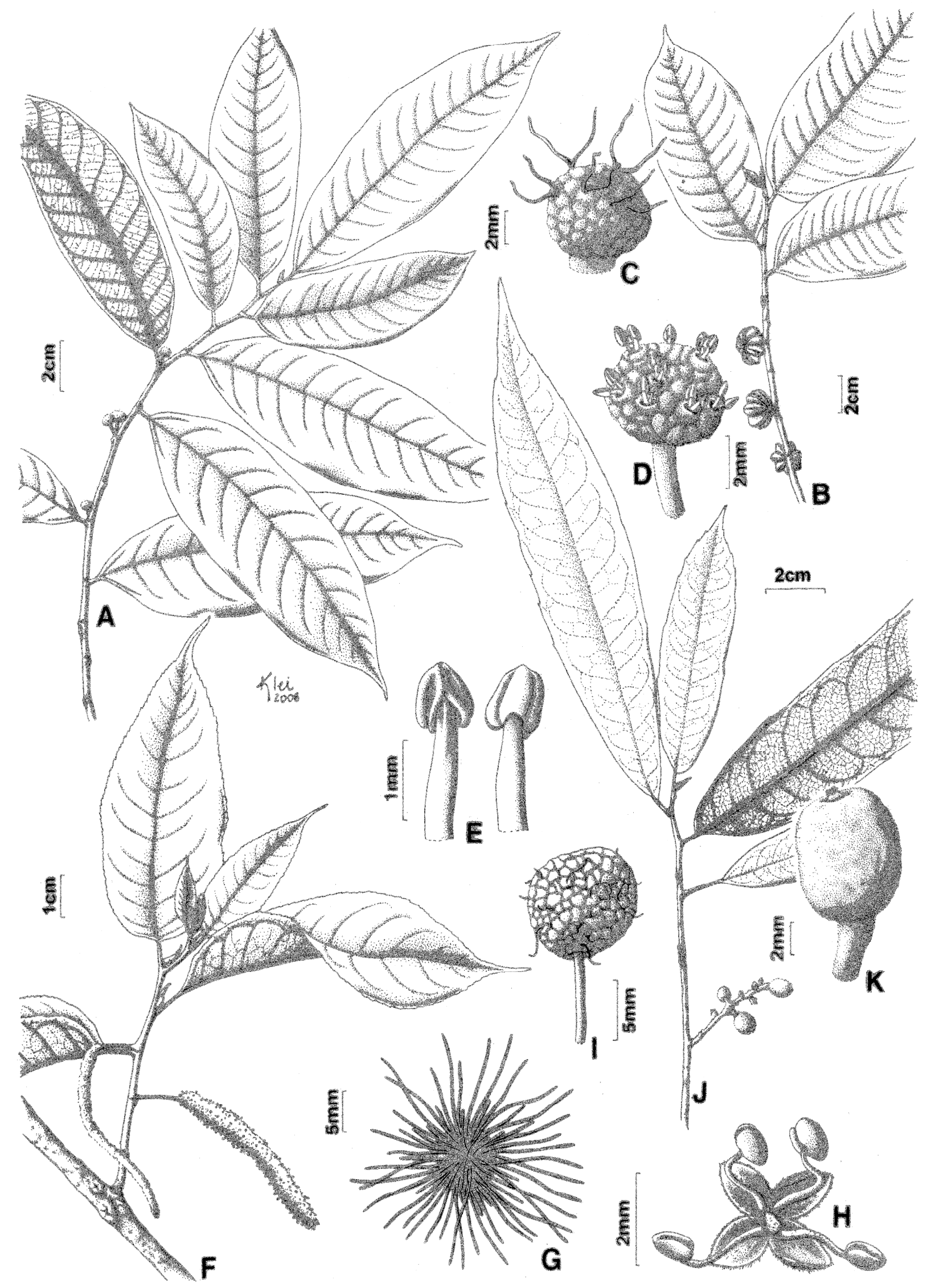




\section{IV.3. URTICACEAE Juss.}

Ervas, arbustos, árvores ou lianas, terrestres ou hemiepífitas, às vezes raízes aéreas ou escoras presentes, raramente latescentes; cistólitos usualmente puntiformes, fusiformes ou lineares. Folhas alternas ou menos frequentemente opostas, raro anisófilas, pecioladas ou sésseis; lâmina simples ou 3-5(-7)-lobada, margem inteira ou serreada, venação actinódroma, raro camptódroma a semicraspedódroma; estípulas inter ou intrapeciolares, fusionadas a completamente amplexicaules. Indumento híspido, estrigoso a tomentoso ou viloso, às vezes tricomas urticantes presentes nas folhas e ramos. Inflorescências axilares, cimeiras ou racemos, pedunculadas ou sésseis, às vezes capitadas, espigadas a sub-umbeladas, geralmente subtendidas por brácteas involucrais, decíduas; flores não vistosas, unissexuadas (plantas monóicas, dióicas ou polígamas), raro bissexuadas, actinomorfas ou zigomorfas (no caso de flores pistiladas), monoclamídeas, raramente aclamídeas; perianto simples, tépalas (1-)2-5(6), livres ou conatas na base, lobadas ou denteadas, prefloração valvar ou imbricada. Flor estaminada: estames em número igual ou menor que as tépalas, raramente o dobro, oposititépalos, livres entre si, inflexos no botão, raro retos; anteras basifixas, rimosas, na antese rapidamente reflexas e ejetando o pólen 2-6-porado ou 15-17forado; pistilódio reduzido ou ausente. Flor pistilada: tépalas desiguais, acrescente após a polinização; ovário súpero, bicarpelar, mas com um dos carpelos extremamente reduzido, oblíquo ou assimétrico, unilocular; óvulo 1, placentação basal ou sub-basal, (sub)ortótropo ou anátropo, às vezes hemianátropo, bitegumentado, crassinucelado; estilete 1, curto, linear ou séssil, geralmente persistente no fruto; estigma capitado, penicelado, ligulado ou filiforme a peltado; estaminódio reduzido, às vezes ausente. Fruto aquênio, às vezes drupáceo, pequeno e livre ou grande e adnato ao perianto acrescente, persistente e suculento, endocarpo crustáceo ou lenhoso; sementes com testa delgada, endosperma presente (ausente em sementes maiores), copioso, embrião reto, pequeno ou grande, cotilédones alados ou compactos.

Urticaceae apresenta 54 gêneros e cerca de 2.600 espécies amplamente distribuídas nas regiões tropicais e temperadas, enquanto no Brasil as estimativas 
apresentam a ocorrência de 12 gêneros e cerca de 80 espécies (Souza \& Lorenzi, 2008; Stevens, 2001). Na Serra do Cipó, o presente trabalho reporta a ocorrência de cinco gêneros com uma espécie cada e um com duas espécies.

O gênero de maior destaque na flora brasileira é Cecropia Loefl., cujas espécies são conhecidas popularmente como embaúbas e geralmente são típicas de formações secundárias ou clareiras no interior de florestas em todo o Brasil. Algumas espécies de urtiga são comuns em bordas de florestas, incluindo aquelas pertencentes aos gêneros Boehmeria Jacq. e Urera Gaudich., que possuem tricomas urticantes que, em alguns casos, como em U. baccifera (L.) Gaudich. (urtigão), podem causar intensa dor quando tocados (Souza \& Lorenzi, 2008).

Urticaceae também apresenta interesse econômico diversificado. Algumas espécies de Cecropia Loefl. são cultivadas como ornamentais, principalmente na arborização urbana. Outros gêneros são cultivados por apresentar folhagem ornamental, incluindo Elatostema J.R.Forst. \& G.Forst. (peliônia-cetim) e Pilea Lindl., este último com espécies conhecidas popularmente como pílea-alumínio ( $P$. cadierei Gagnep. \& Guillaumin), pílea ( $P$. involucrata (Sims) Urb.), brilhantina ( $P$. microphylla (L.) Liebm.), dinheiro-em-penca ( $P$. nummulariifolia (Sw.) Wedd.) e asa-de-anjo ( $P$. spruceana Wedd.). O rami (Boehmeria nivea (L.) Gaudich.) é uma espécie cultivada em diversas partes do mundo, inclusive no Sul do Brasil, pela alta qualidade de suas fibras.

A circunscrição tradicional de Urticaceae tem sido ampliada a partir dos recentes estudos filogenéticos (Sytsma et al., 2002; Monro, 2006; Kravtsova \& Oskolski, 2007), tendo sido incluídos na família os gêneros Cecropia Loefl., Coussapoa Aubl. e Pourouma Aubl., três gêneros neotropicais que eram tradicionalmente reconhecidos em Cecropiaceae.

Os gêneros que eram incluídos em Cecropiaceae C.C.Berg tinham vários caracteres em comum com Urticaceae Juss. Descreveremos alguns desses caracteres utilizados na literatura, que corroboram as afinidades das espécies pertencentes a esses grupos.

O pistilo ocorrente em Cecropiaceae, com estigma simples e óvulo ortótropo basal ou (sub) basal, é típico de Urticaceae. Este tipo de pistilo pode ser relacionado como derivado a partir do tipo de pistilo (com dois estigmas e óvulo anátropo apical) característico de Moraceae e Ulmaceae (Bechtel, 1921). E na transição entre as 
famílias para o tipo de pistilo urticáceo, a redução de um dos dois estiletes ramificados e a posição lateral do óvulo em Castilla tunu Hesml. (Moraceae) são fortes evidências desta transição.

O sistema de tubos laticíferos é reduzido em Cecropiaceae, assim como em Urticaceae (Renner, 1907; Guérin, 1923). Estas plantas não exsudam um látex leitoso, mas uma seiva mucilaginosa que frequentemente torna-se preta (escura) quando exposta ao ar.

O tipo de cistólito que ocorre em Urticaceae pode ser achado em Poikilospermum Zipp. ex Miq. (Renner, 1907; Chew Wee-Lek, 1963), mas está ausente nos outros cinco gêneros de Cecropiaceae (Renner, 1907). Tricomas aracnóides frequentemente encontrados em Boehmeria Jacq. são comuns em Cecropiaceae.

Segundo Berg (1978a), em contraste com Urticaceae, Cecropiaceae seria caracterizada pelo hábito lenhoso, sem qualquer tendência ao hábito herbáceo.

Por fim, um caráter bastante discutido é a presença do tipo urticáceo de estames (dobrados no botão e retos na antese), que diferem dos presentes em Cecropiaceae (retos no botão). Somente poucas espécies de Poikilospermum Zipp. ex Miq., mais especificamente membros do subgênero Poikilospermum, tem estames mais ou menos dobrados, que gradualmente tornam-se retos na antese (Berg, 1977b).

Para Berg (1978b) a diferença entre estames dobrados e retos tem colocado uma importante regra na delimitação dos taxa da família, subfamília ou tribo, apesar de muitos estudantes de Urticales ou partes destes, expressarem alguma dúvida sobre o significado dessa diferença. Corner (1962) considerou tal diferença sem relevância taxonômica, e, nas tribos Artocarpeae e Moreae de seu sistema de classificação de Moraceae, ele incluiu em uma mesma tribo espécies com estames retos e dobrados.

De qualquer maneira, em termos biológicos, os estames dobrados no botão constituem provável adaptação à polinização pelo vento, e as Urticaceae, com poucas exceções, aparentemente dependem do vento como agente polinizador. Berg (1977b) em um estudo sobre a abscisão de anteras em Cecropia Loefl., verificou que aparentes adaptações para a polinização pelo vento foram perdidas em algumas Cecropiaceae, com a provável exceção de Cecropia, que conserva adaptações morfológicas para a anemofilia. Contudo, essas adaptações podem ser apenas uma especialidade do grupo Urticóide, no qual os estames são basicamente retos. 


\section{Chaves para os gêneros presentes na Serra do Cipó}

1. Árvores a raramente arbustos; cistólitos ausentes na lâmina.

2. Folhas peltadas; radialmente lobadas

2. Cecropia.

2'. Folhas basifixas; inteiras ou palmadamente incisivas.

3. Flores estaminadas com 1-2(-3) estames conatos; flores pistiladas sésseis; frutos pequenos; cicatriz da estípula geralmente ascendente; árvores terrestres ou hemiepífitas

3. Coussapoa

3'. Flores estaminadas com 2-4 estames livres; flores pistiladas pediceladas; frutos largos; cicatriz da estípula horizontal; árvores terrestres ....5. Pourouma

1'. Arbustos, subarbustos ou ervas; cistólitos presentes na lâmina.

5. Estigma filiforme, não penicelado; perianto tubular; lâmina oval-orbicular a ovada 1. Boehmeria

5'. Estigma penicelado; perianto 3-4-partido; lâmina elíptica a lanceolada.

6. Folhas alternas; tricomas urticantes presentes; arbustos ou subarbustos até 7 m alt.; ramos sulcados 6. Urera

6'. Folhas opostas; tricomas urticantes ausentes; ervas até $30 \mathrm{~cm}$; ramos não sulcados

4. Pilea 


\section{Boehmeria Jacq.}

Ervas, subarbustos ou arbustos, até $5 \mathrm{~m}$ alt., ramos glabros, às vezes tricomas hirsutos a levemente tomentosos, raramente sulcados ou canaliculados; cistólitos puntiformes, frequentemente presentes na face adaxial; raramente latescentes. Indumento aracnóide, tomentoso, raro estrigoso. Folhas opostas no caule principal, alternas nos ramos laterais, frequentemente simétricas, às vezes assimétricas; margem denteada a serreada; venação actinódroma; estípulas aos pares, livres ou conatas na base, decíduas. Inflorescências axilares, glomerulares, sésseis, dispostas em espigas longas, unissexuadas (plantas monóicas ou dióicas); brácteas pequenas, escariosas; flores estaminadas: perianto 4-lobado, tubular, raramente 3-5-partido, lobos valvados; estames 4, raramente 5-3; pólen 3(-4)-porado; pistilódio reduzido, clavado ou subgloboso, piloso, raramente lanado; flores pistiladas: perianto tubular, membranáceo, contraído, acrescente ao ovário, 2-4-denteado no ápice; estilete alongado, filiforme, piloso unilateralmente; estigma linear, filiforme, não penicelado, persistente no fruto. Fruto aquênio, acrescente ao perianto tubular e persistente.

Boehmeria Jacq. apresenta cerca de 80 a 100 espécies habitando regiões tropicais e subtropicais das Américas, África, Europa e Ásia (Friis, 1993; Pool, 2005). No Brasil ocorrem aproximadamente 16 espécies e na Serra do Cipó é registrada apenas uma espécie - B. caudata Sw.

A filotaxia de Boehmeria Jacq. é muito heterogênea, apresentando folhas alternas e opostas, assim como ocorre em Pouzolzia (Gaudich.) e mais raramente em Pilea Lindl.

Guérin (1923) em estudo sobre as células mucilaginosas, laticíferos e canais secretores das Urticaceae observou a presença de células mucilaginosas em Boehmeria e identificou a presença de cistólitos puntiformes em todas as espécies desse gênero.

O indumento de Boehmeria tem sido estudado por Gangadhera \& Inamdar (1977), os quais observaram a presença de tricomas em forma de gancho no perianto e nas brácteas e indumento aracnóide na face abaxial da folha. 
Em Boehmeria, o perianto tubuloso envolve ligeiramente a núcula, deixando livre o estilete longo e piloso, persistente por algum tempo.

1.1. Boehmeria caudata Sw. Prodr. (Swartz) 34. 1788.

Nome vernacular: assa peixe (SP, Kuhlmann \& Kühn, 1947); urtiga mansa (SP, Crestana et al., 2006)

Figura 13: A - C.

Ervas, subarbustos ou arbustos, às vezes epífitas, eretas ou escandentes, ca. 1,5-6 m compr., caule acinzentado-claro, ramos não sulcados, pubescentes a híspidos. Lâmina (6,8-)7,5-12,1(14,2) cm compr., $(2,5-) 3,6-6,1(7,5) \quad \mathrm{cm}$ larg., elíptica a lanceolada, raramente ovada, membranácea a cartácea, raramente subcoriácea; ápice acuminado a agudo; base frequentemente cuneada a arredondada, raramente subcordada ou atenuada; margem denteada a serreada, raramente crenulada; face adaxial esparsamente estrigosa, às vezes hispidulosa; face abaxial minutamente vilosa, macia ao toque, raramente esparso-híspida; venação actinódroma, impressa na face adaxial e proeminente na abaxial; pecíolos longos, (1,4-)2,3-4,8(-5,5) cm compr., eretos, geralmente tricomas híspidos; estípulas aos pares, (1,8-)2,7-4,5(-5,5) mm compr., ferrugíneas, tomentosas, raramente híspidas; cistólitos puntiformes. Inflorescências em espigas, (2,1-)3,1-6,3(-8,4) cm compr., formando glomérulos; pedúnculo pubescente, raramente híspido; flores rosadas, diminutas, elípticas a lanceoladas, revolutas, vilosas a levemente estrigosas externamente, glabras internamente, creme-esverdeadas a amareladas; flores estaminadas: perianto (1,8-)2,33,2(-3,8) mm compr., (1,3-)1,6-2,2(-2,5) mm larg., 4-meras, tubular, globosa, pedicelada; estames 4 ; filetes $(1,2-) 1,8-2,7(-3,5) \mathrm{mm}$ compr., curvos no botão, retos após a antese; anteras 0,4-0,8 mm compr., oval, marrom-ferrugínea, rimosas, deiscência explosiva; pistilódio oblongo a cilíndrico, colunar, 0,7-1,2 mm compr., 0,3-0,6 mm larg.; flores pistiladas: perianto (2,3-)2,8-3,3(-3,7) mm compr., (0,6-)1,1-1,4(-1,6) mm larg., tubular, denteadas, sésseis, glomérulos ao longo do eixo da inflorescência, esparso-estrigosa, acrescente na frutificação; ovário (0,8-)1,5-1,8(-2,2) mm compr., 0,61,2 mm larg., globoso a ovóide, esparso-estrigoso; estilete 1,2-3,0 mm compr., alongado-filiforme, levemente hispiduloso, em um dos lados; estigma não penicelado, 
curvado, expandido, piloso, persistente. Aquênio (0,7-)2,4-4,6(-6,1) mm compr., (0,4)1,3-1,9(-2,2) mm larg., ovado, comprimido, esparsamente híspido, enegrecido a marrom, acrescente ao perianto.

Material examinado: Minas Gerais, Jaboticatubas, Santana do Riacho, ao longo da rodovia Lagoa Santa - Conceição do Mato Dentro - Diamantina: km 126, J. Semir et al. 4427, 5.IX.1973, fr. (SP, UEC); Santana do Riacho, ao longo da rodovia Belo Horizonte - Conceição do Mato Dentro: km 122, Córrego Três Pontinhas, mata ciliar, A. Furlan et al. CFSC 6965, 11.I.1981, fl., fr. (ICN, SP, SPF); Serra do Cipó, estrada entre a pensão Chapéu do Sol e o Córrego Duas Pontinhas, F.R Salimena-Pires et al. CFSC 10728, 9.X.1987, fl., fr. (SPF).

Material adicional: Minas Gerais, Lagoa Santa e Matozinhos, APA Carste de Lagoa Santa, mata semidecídua, A.E. Brina \& L.V. Costa s.n., 4.III.1996, fl. (BHCB 36584). Rio Grande do Sul, Tenente Portela, Parque Florestal do Turvo, extremo noroeste do RS, Alto do Uruguai, Mata Pluvial Subtropical, J.R. Pirani et al. 487, 19.I.1983, fl. (SP, SPF). São Paulo, Águas de Lindóia, W. Hoehne 6253, 17.III.1968, fl. (SPF); Bananal, à 10 km de São José do Barreiro, M. Kirizawa \& E. leda 1897, 21.VIII.1987, fl. (SP, SPF); Bragança Paulista, Fazenda Santo Antônio, mata perturbada, 2352'30"S 4632'30”W, alt. 820 m, R. Mello-Silva et al. 384, 7.X.1990, fl., fr. (SPF); Cunha, Parque Estadual da Serra do Mar - Núcleo Cunha, Floresta Ombrófila Densa, L.B. Albuquerque et al. 53, 12.XI.1996, fr. (ESA, SPF, UEC); Embu, Almenat, remanescente de mata, 7383'45.4”S 3079'12.0”W, alt. 885 m, N.M. Ivanauskas et al. 6120, 14.XII.2005, fl. (SPF, SPSF); Mairiporã, Parque Estadual da Cantareira, região de Águas Claras, F.A.R.D.P. Arzolla \& A.C. Vasconcelos 220, 4.I.2001, bt. (SPF, SPSF); Santo André, Paranapiacaba, Morro das Torres de TV, S.J. Gomes-Silva et al. 287, 17.XII.1991, fl. (SP, SPF); São Luís do Paraitinga, à $3 \mathrm{~km}$ do núcleo de Santa Virgínia, alto de serra, H.F. Leitão-Filho, et al. 34702, 29.I.1996, fl., fr. (ESA, SPF, UEC).

Espécie bastante comum no leste brasileiro e geralmente encontrado em florestas úmidas de terras baixas, em áreas drenadas, capões de mata, matas ciliares e em florestas semidecidual, geralmente associada a solos residuais a partir de rochas ácidas e calcárias. Na Serra do Cipó ocorre na orla de matas ciliares (como nos Córregos Duas e Três Pontinhas), e na orla ou interior de matas decidual associadas a afloramentos de calcários (como na Área de Proteção Ambiental Morro da Pedreira).

No Estado de São Paulo, B. caudata ocorre como espécie pioneira em florestas estacionais; apresenta moderada sensibilidade à ocorrência de geadas e tolera 
inundações menos prolongadas; geralmente frutifica de novembro a março e suas sementes apresentam baixa densidade, chegando ao número de 1.500 .000 sementes por quiilograma (Crestana et al., 2006).

Trata-se de uma espécie frequentemente utilizada na apicultura, principalmente por características do pólen, e sua madeira, de boa combustão, tem sido frequentemente utilizada como lenha e carvão para o aproveitamento energético (Crestana et al., 2006; Lorenzi \& Souza, 2001).

Kuhlmann \& Kühn (1947) destacaram o cultivo intenso dessa espécie por índios da região do Vale do Rio Camanducaia e pico da Serra Negra, no Estado de São Paulo, os quais utilizavam na fabricação de fibras têxteis e como planta medicinal. 


\section{Cecropia Loefl.}

Árvores, frequentemente com raízes-escora, ramificação candelabriforme, caule e ramos com entrenós ocos (mirmecofilia frequentemente presente); indumento viloso, híspido a esparso-estrigoso, alvo, ferrugíneo, vináceo a prateado. Folhas simples, alternas, raramente opostas, 5-20-lobadas, peltadas, radialmente lobadas, dispostas espiralmente, coriácea a subcoriácea ou cartácea; margem frequentemente denteada; venação actinódroma; estípulas, 5-50 cm compr., fusionadas, amplexicaules; cistólitos ausentes na lâmina; base do pecíolo com ou sem triquílio (região produtora de corpúsculos de Müller, tricomas elipsóides, alvos a vináceos, às vezes ferrugíneos, produtores de proteínas e associados à mirmecofilia). Inflorescências axilares, geralmente aos pares, racemos digitados, às vezes espigados, unissexuados (plantas essencialmente dióicas, raro monóicas), pedunculados, pendentes, cada conjunto envolto por uma espata (bráctea) ampla, decídua; inflorescências estaminadas 1-6 espigas, pistiladas 1-4; flores estaminadas: diminutas, numerosas, perianto tubular, tépalas 2, conatas; estames 2; anteras desconectadas na antese, introrsas; flores pistiladas: isoladas, denso indumento aracnóide, branco; estilete exserto, às vezes bifurcado; estigma peltado ou capitado-penicelado; óvulo basal. Fruto aquênio, pequeno, castanho, seco, envolto por perianto carnoso, endocarpo crustáceo, tuberculado ou denteado. Sementes delgadas, endosperma presente, cotilédones planos, retos.

O gênero Cecropia compreende aproximadamente 100 espécies, com diversidade centrada na região andina, em cujas montanhas e terras baixas adjacentes cerca de 70 espécies já foram descritas (Cuatrecasas, 1982; Berg \& Franco-Rosselli, 2005). A maioria delas ocorre em ambientes úmidos, predominando em áreas secundárias, em bosques e sub-bosques. No Brasil, estimativas (Berg \& FrancoRosselli, 2005) apontam para a ocorrência de 34 espécies distribuídas em três das cinco regiões fitogeográficas neotropicais de Cecropia. Na Serra do Cipó o presente estudo resgistra a ocorrência de duas espécies: $C$. hololeuca Miq. e C. pachystachya Tréc. 
Cecropia é um dos gêneros característicos da flora neotropical. Apesar de ser abundante e apresentar formas distintas, o gênero tem fraca representação nos herbários e nosso conhecimento sobre ele ainda é fragmentário. Assim como vários autores sugerem (Andrade \& Carauta, 1982; Berg, 1996; Romaniuc-Neto, 1999; Vianna-Filho et al., 2005), as coletas dessas plantas têm sido preteridas por uma série de fatores, tais como: ocorrência comum em vegetações e/ou formações secundárias (as quais são frequentemente negligenciadas); grande similaridade entre as espécies; dimensões consideráveis das partes vegetativas e presença de formigas, muitas vezes agressivas. Acrescenta-se a esses fatores, sua morfologia e forma de vida que exigem cuidados especiais quanto à coleta e registros efetuados em campo. Nesse contexto, aspectos que tem dificultado o estudo de materiais de herbário de Cecropia (Carauta \& Schreiber, 1977; Berg \& Simonis, 2000), assim como dos demais representantes urticóides, são coletas compostas de materiais estéreis e incompletos; a falta de anotações de caracteres observáveis apenas em indivíduos vivos e necessários para a determinação em nível específico e por último, descrições muito reduzidas e frequentemente baseadas em um único indivíduo masculino ou feminino.

Muitas das espécies de Cecropia estão associadas com formigas do gênero Azteca em uma relação mutualística. Populações dessas formigas habitam os compartimentos ocos dos caules e ramos (que permitem a entrada desses insetos pelas pequenas perfurações existentes em cada entrenó) e alimentam-se, principalmente, dos corpúsculos müllerianos, tricomas produtores de proteínas encontrados em determinadas espécies de Cecropia. As vantagens deste relacionamento para a formiga são óbvias, contudo ainda estão sendo estudadas as compensações para Cecropia. A primeira hipótese desenvolvida por Müller (1880) tentou explicar que a importante função desempenhada pelas formigas é impedir ou reduzir a herbivoria, particularmente, das formigas cortadeiras. Uma segunda hipótese tentou explicar que a função das formigas é reduzir o super-crescimento das plantas trepadeiras sobre as árvores de Cecropia (Janzen, 1973).

Outra característica particular de Cecropia são as anteras. Na antese, as anteras são comprimidas entre si por meio da abertura do perianto. Em seguida as anteras se separam e se fixam a partes diversas da flor de maneiras diferentes. Em algumas espécies, as anteras permanecem fixas à flor por meio de filamentos engrossados, 
dilatados e espiralados. Na maioria das espécies, as anteras estão ligadas à flor especificamente na margem da abertura do perianto, por meio de apêndices filiformes e pegajosos da teca.

Wijmstra (1967) associa a ocorrência comum de espigas pêndulas na inflorescência estaminada e o mecanismo especial de liberação e re-fixação secundária das anteras supra-descrito a uma provável predominância de polinização anemófila em Cecropia. Não obstante, as inflorescências estaminadas e pistiladas de Cecropia, ao produzirem um leve cheiro adocicado, atraem moscas que acabam utilizando-as como criadouros para suas larvas, conforme identificado por Wheeler (1942), autor que realizou experimentos de criação de moscas do gênero Drosophila em inflorescências estaminadas de Cecropia.

As infrutescências maduras de Cecropia ficam pêndulas e são consumidas principalmente por morcegos e aves, que atuam como dispersores das sementes (Fiebrig, 1909; Huber, 1910; apud Berg, 1978b). Berg (1978b) durante um longo estudo das Cecropia ocorrentes na região amazônica observou em Manaus, o "sanhaçu" (Thraupis episcopus) e a "papira" (Rhamphocelus carbo) muitas vezes comendo tanto infrutescências pêndulas como patentes. Assim, seus frutos são provavelmente dispersos por esses animais, embora outros, como determinadas espécies de macacos, também possam atuar como agentes dispersores.

Contudo, a dispersão hidrocórica também pode ocorrer em Cecropia, principalmente em espécies ocorrentes em matas ciliares e em áreas ocasionalmente inundadas. Parte das infrutescências pêndulas, de diversos centímetros de comprimento e, constituídos por numerosos frutos ligados pelo indumento aracnóide dos periantos, podem desprender-se da raque e cair na água, onde flutuam por algum tempo devido ao ar conservado pelo indumento (Berg, 2000). 


\section{Chaves para as espécies de Cecropia Loefl. presentes na Serra do Cipó}

1. Triquílio ausente no pecíolo; denso indumento aracnóide presente na face adaxial 2.1. C. hololeuca

1'. Triquílio presente no pecíolo; ausência de indumento aracnóide na face adaxial 2.2. C. pachystachya

2.1. Cecropia hololeuca Miquel in Martius, FI. bras. 4(1): 148.1853 .

Nome vernacular. imbaúba branca (BA e ES, Carauta, 1989), imbaúba vermelha (MG, Berg \& Franco-Rosselli, 2005); embaúva-preta (SP, Lorenzi, 2002); embaúba, embraúva, embaúva-vermelha, embaúva-branca, embaúva-prateada (SP, Crestana et al., 2006); embaubaçu, imbaubuçu (RJ), embaúba branca (MG, M. A. Lopes \& P. M. Andrade, BHCB 6437).

Árvore, raramente arvoreta, até $25 \mathrm{~m}$ alt., ramos 2,2-8,5 cm diâm., verdeacastanhados a levemente marrons, hirsutos a densamente vilosos, raramente glabros, às vezes com denso indumento aracnóide, alvo a marrom. Lâmina foliar (16,7-)23,440,3(-49,6) cm compr., (12,6-)18,4-25,7(-42,3) cm larg., segmentos 8-11, partes livres na metade superior coriáceas, oblongas a subovadas, raramente oblanceoladas, incisões abaixo de 7/10- 9/10; ápice arredondado a obtuso, às vezes curto-acuminado; face adaxial, glabra a levemente esparso-estrigosa, denso indumento aracnóide, alvo a acinzentado, levemente áspera ao toque; face abaxial, verde a marrom-escura, indumento aracnóide em aréolas ao longo das nervuras principal e secundárias, levemente macia ao toque; nervuras laterais em partes livres do segmento mediano, 11-19 pares; venação actinódroma, impressa na face adaxial e proeminente na abaxial; pecíolos (15,5-)21,3-40,3(-55,8) cm compr., (0,8-)1,2-2,1(-2,7) cm larg., denso indumento aracnóide, às vezes hirsuto a densamente viloso na base, raramente glabros, ferrugínea a levemente vinácea; triquílios ausentes; estípulas (8,5-)10,1-21,5($25,2) \mathrm{cm}$ compr., alvo-amarelado a marrom-escuro, tricomas creme-amarelado a alvoseríceos ou densamente vilosos, indumento aracnóide externamente, levemente glabro a densamente seríceo internamente. Inflorescências estaminadas aos pares, eretas; 
pedúnculo $(3,8-) 4,4-6,7(-8,8)$ cm compr., glabros ou levemente vilosos, ápice levemente viloso, freqüentemente esparso indumento aracnóide; espata ausente; brácteas raramente presentes; espigas 8-14, (4,8-)7,3-10,5(-13,4) cm compr., $(0,4-) 0,6-0,8(-1,2)$ cm larg., frequentemente moniliforme, vermelho-vinácea a marrom-escuro; estipes $(0,8$ )1,3-1,8(-2,3) cm compr., glabros, indumento aracnóide raramente presente; raque frequentemente vilosa, tricomas delgados, indumento aracnóide. Flores estaminadas: perianto tubular, (0,8-)1,4-2,2(-2,8) mm compr., (0,4-)0,7-1,1(-1,5) mm larg., levemente hirsutos, às vezes glabros, ápice plano, marrom-escuro; filetes alados; anteras $(0,4-$ )0,6-0,8(-1,0) mm compr., (0,3-)0,5-0,7(-0,9) mm larg., creme-amareladas, curtoapendiculadas, semitransparentes, destacadas na antese e re-fixadas secundariamente na margem da abertura apical. Inflorescências pistiladas aos pares: pedúnculo ereto mas depois pêndulo na frutificação, $(4,3-) 6,7-8,5(-11,3) \mathrm{cm}$ compr., glabro a levemente viloso no ápice e na base, vermelho a vináceo-ferrugíneo; espata ausente; brácteas raramente presentes; espigas 1-2 (raramente 3), (4,5-)5,1-10,4(-11,5) cm compr., (0,5)0,8-1,3(-1,8) cm larg., na frutificação, (5,4-)7,6-12,5(-16,7) cm compr., (0,8-)1,2-2,8($3,1) \mathrm{cm}$ larg., inicialmente avermelhadas a rosadas, tornando-se enegrecidas, sésseis, às vezes estipitadas, $0,7-1,4 \mathrm{~cm}$ compr., glabros, à vezes tufo viloso na base; raques levemente vilosa. Flores pistiladas: perianto tubular, (2,6-)3,1-3,7(-4,3) mm compr., $(0,6-$ )0,8-1,3(-1,7) mm larg., denso indumento aracnóide na porção distal, externamente; ápice convexo, muriculado; estilete longo, reto; estigma penicelado. Aquênio, (2,5-)3,64,2(-4,8) mm compr., (0,7-)0,9-1,5(-2,1) mm larg., elipsóide a obovóide, tuberculado, vermelho a marrom-escuro.

Material examinado: Minas Gerais, Itambé do Mato Dentro, Distrito de Santana do Rio Preto (Cabeça de Boi), Serra do Cipó, Mata do Cachoeirão, 19²5'54.7"S 4325'58.3"W, M.F. Santos \& L.M. Borges 206, 18.XII.2007, fl., fr. (SPF).

Material adicional: São Paulo, Bragança Paulista, Fazenda Santo Antônio, divisa com o Sítio Bom Jardim, 135'30”S 46³2'30”W, alt. 820 m., R. Mello-Silva et al. 547, 21.IX.1991, fl., fr. (MBM, NY, SP, SPF); São José dos Campos, M. Kuhlmann \& W. Hoehne 2784, 30.VIII.1949, fl., fr. (SPF); Parque Santo Dias, trilha das Embaúbas, 2339'47"S 4646'21'W, R.J.F. Garcia 54, 8.VIII.1992, fl., fr. (PMSP, SPF). 
Cecropia hololeuca ocorre no leste brasileiro em florestas montanas e submontanas. Na Serra do Cipó ocorre apenas na face leste da serra, ao longo da orla do Rio Preto da Serra da Cabeça de Boi, localizada no distrito de Santana do Rio Preto. Ali, a espécie ocorre na orla de florestas estacionais semidecidual e na orla de córregos e de matas ciliares.

Cecropia hololeuca é uma das únicas espécies do gênero que não apresenta a característica espata, encobrindo as espigas antes da antese. Em vez da espata, às vezes ocorrem uma ou duas brácteas encobrindo as espigas. Os remanescentes da inflorescência permanecem envoltos junto à gema apical até a antese. Essa espécie é facilmente observada e identificada à distância por meio do seu denso indumento aracnóide branco na face adaxial da lâmina que, chegando à fase adulta lhe confere um aspecto prateado. A ausência de triquílio nas folhas é outra característica de fácil identificação em C. hololeuca, que juntamente com C. pittieri B.L. Rob., C. sciadophylla Mart. e C. tacuna C.C. Berg \& P. Franco-Rosselli são as únicas espécies de Cecropia destituídas desse caráter. Berg \& Franco-Rosselli (2005) associaram a presença e ausência de triquílios com a ocorrência de espécies em regiões montanas e submontanas andinas.

Em São Paulo e Minas Gerais, C. hololeuca mostra-se sensível à ocorrência de geadas; frutifica de julho a novembro, chegando a produzir 900.000 sementes por quiilograma. Trata-se de espécie pioneira e tolerante a inundações menos prolongadas, habitando, principalmente, as florestas Ombrófila Densa, Estacional e Ombrófila Mista (Crestana et al., 2006; Lorenzi \& Souza, 2001).

Frequentemente utilizada na arborização urbana de logradouros e praças públicas, e na ornamentação de parques e jardins botânicos, $C$. hololeuca apresenta também propriedades medicinais e seus frutos são geralmente utilizados para alimentação de pássaros e mastofauna (Crestana et al., 2006). Sua madeira pode ser empregada na confecção de objetos leves, como fósforos, caixotaria, lápis, brinquedos, aeromodelismo, tamancos, assim como salto para calçados (Lorenzi, 2002). A árvore confere um aspecto muito característico à fisionomia das matas onde ocorre, em virtude de sua folhagem prateada que sobressai no meio do verde. 
2.2. Cecropia pachystachya Trécul, Ann. Sci. Nat. Bot., ser. 3, 8: 80. 1847.

Nome vernacular: imbaúba vermelha (BA); torém (CE); embaúba-rosa (GO, Martins et al., 2007); embaúba branca (PE); pau de formiga, torem (PI); embaúba, embaúva-branca, embaúva verde (SP, Crestana et al., 2006); ambahú, ambaíba-tinga, ambaí, ambati, árvores da preguiça, ibaíba, imbaúba branca, imbaubão, pau de lixa (RJ), umbaubeira, umbaúba-do-brejo, ambaíba, caixeta-do-campo (SP, Lorenzi, 2002).

Figura 12: A - F.

Árvores ou arvoretas, 3,5-12,5 m alt.; ramos 1,5-4,8 cm diâm., ramos verde-alvos a alvo-amarronzados; tricomas híspidos a densamente tomentosos, às vezes indumento aracnóide. Lâmina foliar (6,5-)12,5-20,5(-25,3) cm compr., (14,8-)15,5,-20,4(30,3)cm larg.; segmentos 9-13, partes livres no segmento superior oblanceoladas a sub-obovadas, coriácea a subcoriácea ou cartácea, frequentemente lobada a sinuada, incisões abaixo de (5/10-)7/10-9/10, às vezes abaixo de 2,4 cm a partir do pecíolo; ápice curto-acuminado a levemente sub-obtuso; face adaxial escabra a híspida, às vezes esparso-hirsuta, levemente marrom-esverdeada a amarelo-ferrugínea, áspera ao toque; face abaxial levemente pubérula a tomentosa, mais densamente ao longo das nervuras mediana e secundárias, alvo-amarelada a ferrugínea-clara; indumento aracnóide em aréolas sobre as nervuras menores e mediana, às vezes apenas na nervura mediana e nas margens, macio ao toque; nervuras laterais em partes livres do segmento mediano, 9-20 pares; venação actinódroma, impressa na face adaxial e proeminente na abaxial; pecíolo (10,4-)17,5-32,5(-40,2) cm compr., hirtelo a densamente tomentoso, esparso a denso indumento aracnóide, verde-ferrugíneo a marrom-escuro; triquílio presente, fusionado, indumento marrom a alvo; estípula (6,7)9,3-13,4(-15,6) cm compr., alvo-esverdeada a vinácea, macia ao toque, levemente serícea a tomentosa, com denso indumento aracnóide externamente, glabra a levemente vilosa internamente. Inflorescências estaminadas aos pares; pedúnculo ereto ou deflexo, espigas eretas, pêndulas na antese; pedúnculo $(4,6-) 5,5-7,8(-10,5) \mathrm{cm}$ compr., hirsuto a densamente tomentoso ou minutamente puberuloso, frequentemente com denso indumento aracnóide; espata (3,5-)5,3-6,8(-8,2) cm compr., alvo-esverdeada a marrom-vinácea, com máculas alvas, levemente serícea a tomentosa, denso indumento aracnóide externamente, macia ao toque, glabra a levemente vilosa 
internamente; espigas 5-12, (1,5-)3,5-5,7(-9,5) cm compr., (0,2-)0,4-0,6(-0,9) cm larg.; estipe $0,1-0,4 \mathrm{~cm}$ compr., esparso a densamente vilosa, em tufo ou glabra; raque levemente vilosa. Flores estaminadas: perianto tubular, $(0,8-) 1,5-2,1(-2,6) \mathrm{mm}$ compr., $(0,4-) 0,6-0,8(-1,1) \mathrm{mm}$ larg., glabro, ápice plano, marrom-ferrugínea; filetes alados; anteras (0,3-)0,5-0,7(-0,9) mm compr., $(0,2-) 0,4-0,6(-0,8) \mathrm{mm}$ larg., amareladas, apendiculadas, destacadas na antese e re-fixadas secundariamente na margem da abertura do perianto por apêndices finíssimos, semitransparentes. Inflorescências pistiladas aos pares, pedunculadas, eretas ou deflexas, espigas pêndulas na frutificação; pedúnculo $(3,5-) 4,5-9,5(-11,5) \quad \mathrm{cm}$ compr., indumento similar às inflorescências estaminadas; espata $(2,5-) 4,2-5,5(-7,2) \mathrm{cm}$ compr., cor e indumento semelhante às inflorescências estaminadas; espigas 4-6(-7), (4,5-)6,4-8,7(-12,2) cm compr., (0,4-)0,6-0,9(-1,3) cm larg., na frutificação $(9,5-) 12,7-15,3(-17,6) \mathrm{cm}$ compr., $(0,6-) 0,9-1,2(-1,5) \mathrm{cm}$ larg., sésseis ou estipitadas, 0,1-0,3 cm compr., tufo pubérulo; raque levemente vilosa. Flores pistiladas: perianto $(0,9-) 1,2-1,4(-1,6) \mathrm{mm}$ compr., com denso indumento aracnóide entre as flores, na base, no ápice e no canal do estilete, internamente; estilete curto; estigma peltado, levemente penicelado. Aquênio, oval a oblongo, (1,1-)1,5-1,8(-2,2) mm compr., (0,6-)1,0-1,3(-1,6) mm larg., tuberculado, marrom escuro.

Material examinado: Minas Gerais, Itambé do Mato Dentro, localidade Canta Galo, próximo a córrego, J.R. Stehmann \& M.E. Sobral 1129, 8.VIII.1992, fr. (BHCB, MBM); próximo a ponte sobre córrego, J.R. Stehmann \& M.E. Sobral 1128, 8.VIII.1992, bt. (UEC); distrito de Santana do Rio Preto (Cabeça de Boi), 19ㅇ 24' 08.5"S 4324'08.5" W, M.F. Santos \& E.G.A. Martins 160, 24.VIII.2007, fl., fr. (SPF); Beira da estrada Itambé do Mato Dentro - Santana do Rio Preto, 1924'08.5"S 4324'08.5" W, M.F. Santos \& H.F. Serafim 356, 15.II.2007, fl., fr. (SPF); Jaboticatubas, ao longo da rodovia Lagoa Santa - Conceição do Mato Dentro Diamantina, na estrada da Usina, J. Semir \& A.M. Giulietti 5026, 21.V.1974, fl. (UEC); km 177, beira do rio, J. Semir et al. 4395, IV.IX.1973, fl. (SP); Santana do Riacho, Cardeal Mota, Morro da Pedreira (blocos do Grupo II), afloramentos de calcários na base da serra, Fazenda Canto da Serra, J.R. Pirani et al. CFSC 13251, 21.V.1989, fl. (SP, SPF); APA Morro da Pedreira (blocos do Grupo I), base dos afloramentos de metacalcários, 191' $47.7^{\prime \prime S} 43^{\circ} 36^{\prime} 38.8^{\prime \prime W}$, alt. 845 m, E.G.A. Martins \& M.F. Santos 110, fl., fr. (SPF); Serra do Cipó, rodovia Lagoa Santa Conceição do Mato Dentro (MG-010): km 101, margem direita da curva do mirante, E.G.A. 
Martins et al. 69, 13.Il.2007, fl., (SPF); Km 87, margem direita, cerrado, 19²3'00.9"S 4341'46.6"W, E.G.A. Martins et al. 43, 23.IX.2006, bt. (SPF); margem da estrada, ao lado de mina d'água, 800 m, Espósito 23, 15.IX.1990, fr. (BHCB); km 105, próximo ao Hotel Chapéu do Sol, I. Cordeiro et al. CFSC 11188, 29.VI.1988, fl. (SP); Córrego Três Pontinhas, em mata ciliar, 1917’S 4333'W, I. Cordeiro et al. CFSC 11190, 29.VI.1988, fl., fr. (SP); Serra do Cipó, Córrego Duas Pontinhas, campo rupestre e mata ciliar, 1919'S 4334'W, alt. 1220 m, D.C. Zappi et al. CFSC 10335, 21.VII.1987, fl. (SP, SPF); Mãe D’água, Vale do Córrego Véu da Noiva, acima da cachoeira, J.R. Pirani CFSC 11479, 21.V.1989, fl. (SP, SPF); Estrada de acesso à Usina Américo Teixeira - UCAT, $100 \mathrm{~m}$ após a ponte sobre o Rio Indequicé, 1915'57.1"S 4335’21”W, E.G.A. Martins \& C. Delfini 112, 15.II.2007, fl., fr. (SPF).

Material adicional: Bahia, Abaíra, estrada nova Abaíra-Catolés, próximo a São José, sobre rochas areníticas, 131'ㅇ 4142'W, alt. 750-900 m, R.M. Harley et al. 50510, 28.XII.1992, fl., fr. (CEPEC, HUEFS, K, SPF). Minas Gerais, Araguari, ao longo da rodovia BR-050, próximo ao Rio Araguari, G. Hatschbach 42244, 10.VII.1979, fl., fr. (MBM); Grão-Mogol, Vale do Riacho Ribeirão, J.R. Pirani \& R. Mello-Silva CFSC 10878, 24.V.1987, fl. (GUA, SPF); Leopoldina, ao longo da rodovia BR-116, encosta de morro, G. Hatschbach \& O. Guimarães 45015, 14.VII.1982, fl. (MBM). São Paulo, Cananéia, Ilha do Cardoso, S. Romaniuc-Neto et al. 778, 26.VIII.1988, fl., fr. (SP, SPF).

No Brasil, Cecropia pachystachya ocorre a partir do sul da Amazônia, nos estados do Amazonas, Bahia, Ceará, Espírito Santo, Goiás, Maranhão, Mato Grosso, Mato Grasso do Sul, Minas Gerais, Pará, Paraíba, Pernambuco, Piauí, Paraná, Rio de Janeiro, Rio Grande do Sul, Santa Catarina, São Paulo e Distrito Federal (Martins et al., 2007), e estende-se até o Paraguai e norte da Argentina, habitando florestas, cerrados e áreas de restinga. Trata-se de uma planta perenifólia, heliófila, pioneira e seletiva higrófita, característica de solos úmidos na orla de matas e em suas clareiras. Na Serra do Cipó ocorre na orla de mata ciliar e de capões de mata, sendo rara em seu interior, e também em matas semidecidual e nas clareiras ou capoeiras situadas junto a vertentes ou cursos d'água ou em terrenos baixos com lençol freático superficial.

Cecropia pachystachya é muito variável nas características presentes nas margens dos segmentos, nos lobos e na densidade do indumento aracnóide. Folhas com denso indumento aracnóide são comuns no sul e no leste do Brasil. Nas espécies provenientes de Minas Gerais encontraram-se grande diferença na profundidade das 
incisões próximas ao pecíolo. Em materiais de herbários, C. pachystachya tem sido frequentemente confundida com $C$. concolor Willd., porém diferenças no indumento dos triquílios e nos lobos dos segmentos da lâmina foliar distingue facilmente estas duas espécies.

Em estudo das espécies de Cecropia da Amazônia brasileira, Berg (1978b) verificou que as espécies de terra firme florescem o ano todo (assim como muitas plantas pioneiras), embora haja indivíduos que florescem intermitentemente. Na Serra do Cipó verificaram-se indivíduos de C. pachystachya Tréc. florescendo e frutificando em épocas de chuvas, chegando, nesse período, à formação de colônias ou populações, como observado em 2007, na região do córrego Mãe D’Água. Assim, observa-se que a frutificação e a floração dos espécimes sujeitos a esses ambientes, estão estreitamente correlacionadas ao nível estacional de disponibilidade hídrica.

Cecropia pachystachya apresenta um interesse econômico e uso diversificado.

Sua madeira pode ser empregada na confecção de brinquedos, caixotaria leve, saltos para calçados, lápis, compensados e polpa celulósica. Da mesma forma, sua forma característica de ramificação - candelabriforme - apresenta qualidades ornamentais e paisagísticas. Suas folhas são muito apreciadas pelo bicho-preguiça e seus frutos, produzidos anualmente em grande quantidade, são avidamente procurados por muitas espécies de pássaros. Além disso, devido a sua rapidez de crescimento, ela é indispensável nos reflorestamentos heterogêneos de áreas degradadas de preservação permanente (Lorenzi, 2002). 


\section{Coussapoa Aubl.}

Árvores ou arbustos terrestres ou hemiepífitas, até $40 \mathrm{~m}$ alt., com raízes aéreas e às vezes raízes-suporte; ramos fistulosos frequentemente presentes; indumento aracnóide geralmente presente; mirmecofilia presente eventualmente. Folhas alternas, basifixas, inteiras; venação broquidódroma, às vezes semicraspedódroma, raramente actinódroma; pecíolos longos; estípulas amplexicaules, conatas, decíduas, deixando cicatrizes ascendentes no ramo, oblíquas; cistólitos ausentes na lâmina. Inflorescências cimosas, pedunculadas, dicotomicamente ramificadas, unissexuadas (plantas estritamente dióicas, raramente monóicas); brácteas interflorais presentes, às vezes ausentes; inflorescências pistiladas frequentemente não ramificadas, geralmente reduzidas a um glomérulo globoso a raramente elipsóide; inflorescências estaminadas em vários capítulos globosos. Flores estaminadas: pequenas, geralmente pedunculadas, perianto 3(-4)-lobado, frequentemente conato e tubular; estames (1-)2-3, inteiramente conatos; filetes de comprimento variado. Flores pistiladas: sésseis, perianto (2-)3(-4), tubular, inteiramente conato ou às vezes peças livres; estigma 1, capitado-penicelado; ovário livre; óvulo basal, sub-ortótropo. Fruto pequeno, seco, geralmente drupáceo, envolto por um perianto frequentemente carnoso, esverdeado a alaranjado; endocarpo verrugoso; sementes pequenas, endosperma escasso, às vezes ausente, cotilédones planos.

Este gênero compreende cerca 50 espécies amplamente distribuídas em áreas tropicais úmidas da América do Sul e Central. A maioria das espécies é componente de florestas úmidas de terras baixas. Poucas espécies, como por exemplo, C. villosa Poepp. \& Endl. e C. asperifolia Trécul, habitam florestas montanas e submontanas (Berg et al., 1990).

Coussapoa foi revisado por C.C. Berg, R.W.A.P. Akkermans e E.C.H. van Heusden (1990) para a Flora Neotropica no seu volume 51 e na última década do século XX tem sido tratado em floras regionais como Flora do Equador (Berg \& FrancoRosselli, 1993) e Flora da Guiana Venezuelana (Berg, 1998). Para Berg et al. (1990) o pobre estado de exploração botânica em regiões neotropicais tem afetado adversamente a revisão desse gênero, pois, entre outros fatores, muitas espécies são 
conhecidas a partir de uma única coleta ou poucos espécimes. Mais de 1/4 (um quarto) das espécies conhecidas de Coussapoa foram descritas durante a preparação de sua revisão para região neotropical. De um modo geral, desde o estabelecimento do gênero Coussapoa por Aublet (1775), o qual descreveu duas espécies a partir da Guiana Francesa, nomes tem sido adicionados por Trécul (1847), Klotzsch (1847), Miquel (1853), Standley (1919, 1937b), Mildbraed (1942) e Cuatrecasas (1951 e 1956b), chegando a um total de 90 nomes criados. Contudo, Berg et al. (1990) reconheceram um total de 34 espécies na referida revisão para a série Flora Neotropica.

Berg et al. (1990) destacaram também os problemas da obtenção de um arranjo sistemático satisfatório do grupo, uma vez que a maior parte dos caracteres diagnósticos na taxonomia do gênero apresenta descontinuidades e variações estruturais.

A maior parte das espécies de Coussapoa são hemiepífitas arbóreas com uma forma de vida diferenciada, compartilhada com poucos outros gêneros, como por exemplo, Ficus (subg. Urostigma), Clusia L. (Clusiaceae) e Schefflera J.R.Forst. \& G.Forst. (Araliaceae). As Coussapoa hemiepífitas apresentam características ecológicas similares, assim como demonstram pouca variação nos seus caracteres morfológicos. O hábito hemiepifítico de crescimento é evidente quando há presença de raízes aéreas. Tais raízes podem formar ramificações em forma de cesto ao redor do caule da árvore hospedeira, à maneira do que ocorre com espécies hemiepífitas de Ficus, conferindo a essas espécies de Coussapoa a denominação de "falsaestranguladora".

Em Coussapoa, assim como em Poikilospermum Zipp. ex Miq., gêneros tipicamente epifíticos, apresentam um fruto ovóide encoberto por perianto suculento e endocarpo lenhoso que, após a decomposição da parede carnosa do fruto, abre-se em duas válvulas para liberar a semente que, até essa fase, encontra-se presa lateralmente acima da base do carpelo (Friis, 1993; Barroso et al., 1999).

Como em várias outras hemiepífitas, a ocorrência de frutos vermelhos em Coussapoa é muito comum. Isso atrai uma grande quantidade de espécies, principalmente de aves, tornando esse gênero muito importantes na dieta alimentar de muitos animais. No entanto, estudos biológicos com espécies hemiepífitas são raros, principalmente para as espécies neotropicais. 
3.1. Coussapoa microcarpa (Schott) Rizzini, Dusenia 1(5): 295. 1950.

Nome vernacular: figueirinha, figueira, figueira mata-pau (SP, Crestana et al., 2006).

Figura 12: G-K.

Árvores ou arbustos terrestres ou hemiepífitas, de 8 a $20 \mathrm{~m}$ alt., ramos de 2-4 m diâm., creme-ferrugíneos a amarelados, às vezes acinzentados e rugosos; tricomas pubérulos a levemente hirtelos ou hirsutos, às vezes denso indumento aracnóide, alvo a marrom. Lâmina foliar (2,1-)7,8-11,5(-18,4) cm compr., (1,8-)3,6-6,5(-8,7) cm larg., subobovada a ovada, oblonga, ou elíptica a lanceolada, coriácea a sub-coriácea, raramente cartácea; ápice levemente acuminado a agudo, às vezes obtuso; base aguda a obtusa ou arredondada; margem inteira, geralmente revoluta em direção a base; face adaxial glabra, raramente esparso-hirsuta a levemente pubérula ou estrigosa, marrom-escura a ferrugínea; face abaxial glabra a esparsamente estrigosa ou pubérula a levemente hirsuta sobre a nervura mediana, claro-ferrugínea a alaranjada; nervuras laterais (5-)611(-13) pares, par basal não ramificado, atingindo a margem abaixo da nervura mediana da lâmina; venação broquidódroma, às vezes actinódroma, impressa na face adaxial e levemente proeminente na abaxial; pecíolo $(0,8-) 2,1-3,5(-4,6) \mathrm{cm}$ compr., densamente pubérulo a hirtelo ou levemente hirsuto, marrom a acinzentado; estípulas $(0,8-)$ 1,3-2,2(-3,1) cm compr., alvo a amarelada, levemente prateada, densamente pubérula a tomentosa ou hirsuta, com indumento aracnóide marrom-claro, macio ao toque externamente, glabro internamente, marrom-escuro. Inflorescências estaminadas: ramificadas, capítulos globosos, (1,2-)2,3-2,7(-3,2) mm diâm.; pedúnculo comum, (0,4) 0,8-1,2(-2,1) cm compr., densamente pubérulo a hirteloso, marrom-escuro; flores estaminadas, perianto (0,3-)0,5-0,8(-1,3) mm compr., 0,3-0,7 mm larg., glabro, ápice plano, creme-esverdeado; estames 2 , raramente 3 , conatos; anteras 0,2-0,4 mm compr., 0,1-0,3 mm larg., amareladas, rimosas. Inflorescências pistiladas: não ramificadas ou raramente ramificadas; capítulos globosos, (2,5-)4,7-6,4(-7,2) mm diâm., na frutificação atingindo 10 mm diâm.; pedúnculo comum (0,5-)1,2-2,2(-2,8) cm compr., densamente pubérulo a hirtelo, creme-amarelado e ferrugíneo; flores pistiladas sésseis; perianto 0,4-1,2 mm compr., 0,3-0,6 mm larg., tubular, conato, glabro, acrescente na frutificação, verde-amarelado a alaranjado; estilete curto; estigma penicelado, roxo a 
vináceo; brácteas interflorais pequenas, estreitamente espatuladas, frequentemente 1 a 2 , às vezes ausente. Aquênio, pequeno, ovóide, (1,1-)1,5-2,1(-2,6) mm compr., (0,7)1,1-1,6(-2,0), estigma persistente, creme-amarelado a alaranjado, máculas alvas.

Material examinado: Minas Gerais, Itambé do Mato Dentro, distrito de Santana do Rio Preto (Cabeça de Boi), margem do Córrego Cipó, à meia altura da serra, 19²3'38.4"S 4335'41.3"W, M.F. Santos \& E.G.A. Martins 165, 25.VIII.2007, fl. (SPF); idem, M.F. Santos \& H.F. Serafim 296, 14.III.2008, fl., fr. (SPF); Mata do Cachoeirão, 1925'54.7"S 43ํ25'58.3"W, M.F. Santos \& H.F. Serafim 269, 13.III.2008, fl., fr. (SPF); Santana do Riacho, ao longo da rodovia Belo Horizonte - Conceição do Mato Dentro: km 116, margem do Rio Santo Antonio, L. Rossi \& M.C.E. Amaral CFSC 7260, 19.IV.1981, fl., fr. (SPF).

Material adicional: Minas Gerais, Carangola, Rio Carangola, na Ilha Encantada, acima da Cachoeira do Boi, 2043'S 420ํ'W, alt. 500 m, L.S. Leoni et al. 1037, 6.l.1990, fl. (GFJP, SPF); Conceição do Mato Dentro, Parque Natural Municipal do Ribeirão do Campo, em mata ciliar, 1906'01.8”S 433'48.9”W, R.C. Mota et al. 1671, 10.X.2002, fl., fr. (BHCB); Mariana, Pequena Central Hidrelétrica de Furquim, na margem esquerda do Ribeirão do Carmo, $E$. Tameirão-Neto 3480, 5.VIII.2002, fr. (BHCB, SPF). São Paulo, Caieiras, Fazenda da Companhia Melhoramentos, em mata seca, A.M. Giulietti et al. 1195, 17.VIII.1994, fr. (SP, SPF); Cananéia, Ilha do Cardoso, em floresta pluvial atlântica, J.R. Pirani et al. 2047, 5.XII.1987, fl., fr. (F, MBM, SP, SPF); base do Morro do Foles, em mata de restinga, S. Romaniuc-Neto et al. 765, 24.VIII.1988, fl. (SP, SPF).

No Brasil ocorre do Rio Grande do Sul ao Espírito Santo, comum em florestas acima de $1300 \mathrm{~m}$ e em vegetação de restinga. Além disso, habita geralmente em populações isoladas ao norte da Bahia e na Paraíba e Pernambuco, em topos de montanhas. Na Serra do Cipó ocorre tanto na sua face leste quanto na oeste, habitando sempre na orla de rio e de mata ciliar.

Várias espécies de Coussapoa ocorrentes em áreas de média extensão demonstram certa descontinuidade na sua distribuição. Entretanto, segundo Berg et al. (1990) não está claro se esta descontinuidade é real ou se é devido a uma insuficiência na amostragem em cada área. Para o caso de C. microcarpa, a descontinuidade na sua distribuição, especialmente os registros de ocorrência em áreas isoladas de Pernambuco e Paraíba, poderia estar relacionado com a ocorrência restrita aos "brejos 
de altitude", que são ilhas de florestas úmidas nos topos de serras no domínio das caatingas.

Coussapoa microcarpa exibe grande variabilidade na forma e dimensão da lâmina foliar, mas compartilha semelhanças foliares com $C$. latifolia Aubl. e $C$. microcephala Trécul.

Essa espécie apresenta tricomas em formato de corpos perolados (ou glândulas), hialinos e suculentos, e confinados às folhas. Esses corpos perolados são provavelmente numerosos na espécie, mas frequentemente não identificados no campo devido ao fato de serem facilmente destacados ou mesmo ceifados por formigas (O’Dowd, 1982).

Nos estados de Minas Gerais e São Paulo, populações de C. microcarpa geralmente são encontradas em restingas, na Floresta Ombrófila Densa e na Floresta Estacional. Sua frutificação ocorre frequentemente em abril e maio, chegando suas sementes a apresentarem uma densidade de até 1.500 .000 por quilograma. É uma espécie de clímax, onde germina e cresce à sombra, atingindo depois o dossel e só então entrando em fase reprodutiva. Embora sejam mais comuns em solos com maior disponibilidade hídrica, podem tolerar períodos de seca (Crestana et al., 2006; Lorenzi \& Souza, 2001).

Os frutos $C$. microcarpa tem sido frequentemente utilizados para a alimentação de pássaros e mastofauna (Crestana et al., 2006). A espécie tem sido cultivada em várias casas de vegetação da Holanda para uso ornamental, principalmente devido à beleza e durabilidade de suas folhas. 


\section{Pilea Lindl.}

Ervas, anuais ou perenes, raramente subarbustos, ramos frequentemente alaranjados a creme-esverdeados, às vezes difusos; tricomas urticantes ausentes. Folhas opostas, pares assimétricos, serreadas ou denteadas, às vezes inteiras; venação frequentemente actinódroma; estípulas intrapeciolares, completamente fusionadas aos pares; cistólitos lineares, fusiformes, raramente puntiformes, frequentes na face adaxial, às vezes na abaxial. Inflorescências axilares, cimeiras isoladas, paniculadas, capitadas ou em espigas; brácteas pequenas, largas; flores unissexuadas (plantas monóicas ou dióicas); flores estaminadas: perianto com (2-)3-4-tépalas fusionadas na base, partidas no ápice, segmentos côncavos, sub-valvados, protuberâncias verticais na face externa próxima ao ápice, frequentemente cuculadas ou corniculares; estames 4, raramente 2-3; pistilódio reduzido, cônico ou oblongo; flores pistiladas: perianto com 3-tépalas partidas, iguais ou distintas, denteadas; estaminódio reduzido, semelhante a escama, diminuto ou inconspícuo; ovário reto; estigma séssil, penicelado. Aquênio ovado a orbiculado, contraído, levemente oblíquo, às vezes parcialmente envolto pelo perianto.

Existem cerca 600-700 espécies de Pilea (Pool, 2005; Monro, 2004; 2006), gênero com distribuição pantropical, habitando regiões tropicais e quentes do Velho e do Novo Mundo, mais raramente na Austrália e na Nova Zelândia. Chen (1982) incluiu em sua revisão das espécies chinesas de Pilea, um número previamente aceito para o gênero e reconheceu sete seções. Contudo, para esses autores o gênero está urgentemente necessitando de revisão, especialmente as espécies tropicais da América e Ásia.

No Brasil ocorrem cerca 21 espécies e na Serra do Cipó apenas uma espécie Pilea microphylla (L.) Liebm. Espécies desse gênero estão frequentemente associadas a solos carbonáticos. 
4.1. Pilea microphylla (L.) Liebm., Kongel. Danske Vidensk. Selsk. Skr. Naturvidensk. Math. Afh. ser. 5, 2: 296. 1851.

Nome vernacular: brilhantina (SP, Souza \& Lorenzi, 2008);

Figura 13: D - G.

Ervas suculentas, eretas ou decumbentes, formando almofadas de até $24 \mathrm{~cm}$ alt., frequentemente diminutas; ramos glabros, esverdeados a amarelados na estação seca, não sulcados. Lâminas foliares opostas, 2 a 3 pares por nó, pares assimétricos; pares maiores: (0,3-)2,4-5,0(-9,3) mm compr., (0,2-)2,3-3,5(-5,0) mm larg., obovados a ovados, ápice obtuso, base oblíqua, atenuada a cuneada, raramente arredondada, pecíolos (0,2-)1,0-1,8(-2,2) mm compr.; par menor: (0,1-)1,8-3,5(-5,0) mm compr., (0,1)1,2-2,0(-2,9) mm larg., oval a orbicular, raramente elíptica, cordiforme ou reniforme, ápice obtuso ou agudo, às vezes arredondado a subagudo, base oblíqua, arredondada a subcordada; margem inteira a levemente revoluta, pontuações carbonáticas presentes na margem; face adaxial glabra, cistólitos lineares, fusiformes, transversais na lâmina, venação não-evidente; face abaxial glabra, cistólitos lineares, fusiformes menos frequente ou ausente; venação broquidódroma, às vezes actinódroma. Inflorescências cimosas, ramificadas, estaminadas e pistiladas às vezes no mesmo nó, pedunculadas, avermelhadas, (0,6-)1,5-2,7(-3,1) $\mathrm{mm}$ compr., flores unissexuadas (plantas monóicas, raramente dióicas), alvas, diminutas, globulares, axilares, sésseis ou pedunculadas. Flores estaminadas: perianto com 4-tépalas, às vezes partidas, $(0,2-$ ) 0,5-0,8(-1,2) mm compr., 0,3-1,0 mm larg., máculas vermelhas na base, cistólitos fusiformes na face externa, ápice vertical formando uma concavidade; pedicelo $(0,4-$ ) 0,7-1,5(-1,8) mm compr., retangulares; estames 4, opositissépalos, 0,5-0,8 mm compr., 0,2-0,4 mm larg.; anteras rimosas. Flores pistiladas: perianto 3-tépalas, segmento mediano maior e com apêndice cornicular no ápice, laterais idênticos, $(0,3-) 0,5-0,8(-1,2)$ mm compr., 0,3-0,5 mm larg., cistólitos ausentes; pedicelo $(0,3-) 2,1-2,8(-3,2) \mathrm{mm}$ compr.; ovário globoso, elíptico, 0,3-0,5 mm compr., 0,2-0,4 mm larg., vermelho a alaranjado; estilete curto, dilatado; estigma penicelado. Aquênios ovados, 0,3-0,6 mm compr., 0,2-0,4 mm larg., marrom-ferrugíneo a alaranjado, estigma persistente; sementes oblongas, achatadas, proximal enegrecido a vináceo, endosperma ausente. 
Material examinado: Minas Gerais, Santana do Riacho, Cardeal Mota - Serra do Cipó, APA Morro da Pedreira, alto dos afloramentos de metacalcários (blocos do Grupo I), 1918'19.3”S 4336'50.0”W, alt. 920 m, E.G.A. Martins et al. 54, 17.I.2007, fl., fr. (SPF); afloramentos de metacalcários (blocos do Grupo I), 19²0'S 4336’'W, alt. $920 \mathrm{~m}$, floresta decidual, E.G.A. Martins et al. 34, 20.VII.2006, fl., fr. (SPF); alto dos afloramentos de metacalcários (blocos do Grupo I), floresta decidual, formando tapetes sobre as rochas, 1918'23.3"S 4336'54.9”W, alt. 959, E.G.A. Martins et al. 107, 23.V.2007, fl., fr. (SPF); afloramentos de calcários na base da Serra do Cipó (blocos do Grupo III), 19¹8'27.1"S 4336'50”W, alt. 900 m, J.R. Pirani et al. 4993, 5.III.2002, fl., fr. (F, SPF); Serra do Cipó, Morro da Pedreira, grande afloramentos de metacalcários (blocos do Grupo II), 19²0'S 434ㅇ'W, alt. 920 m, J.R. Pirani et al. 3675, 2.IV.1996, fl., fr. (SPF); Serra do Cipó (Serra da Lapa), distrito de São José da Cachoeira, beira da estrada Santana do Riacho - Santana do Pirapama, em vegetação arbustivo-arbórea sobre afloramentos de calcários, V.C Souza et al. 32895, 20.II.2007, fl., fr. (ESA, SPF); Serra do Cipó, ao longo da rodovia Belo Horizonte - Conceição do Mato Dentro: km 104, em mata mesófila, B. Stannard et al. CFCR 5910, 13.XI.1984, fl., fr. (ICN, K, SPF); Serra do Cipó, afloramento de calcários ao longo da rodovia Belo Horizonte Conceição do Mato Dentro, R. Simão et al. CFSC 10123, 8.V.1987, fl., fr. (SPF); Morro da Pedreira (blocos do Grupo II), afloramentos de calcários na base da Serra do Cipó: Fazenda Canto da Serra, J.R. Pirani et al. CFSC 13283, 22.VII.1993, fl., fr. (SPF).

Material adicional: Minas gerais, Arcos, afloramentos de calcários, M.A. Rollo s.n., 24.I.1991, fr. (SPF 168363); Santo Hipólito, 5 km após Santo Hipólito em direção a Monjolos, antigo leito de estrada de ferro, sobre afloramentos de calcários à margem esquerda do Rio Pardo Pequeno, 181'17'S 4411'06"W, alt. 500 m, R. Mello-Silva et al. 1324, 24.III.1997, fl. (K, MBM, NY, SPF); estrada Santo Hipólito - Conselheiro Mata, em borda de floresta sobre rochas calcárias, 1817'08.1"S 4411'11.8”W, alt. 550 m, V.C. Souza et al. 28136, fl. (ESA, SPF). São Paulo, São Paulo, Horto do Viveiro Manequinho Lopes, L. Rossi 215, 6.VIII.1984, fl., fr. (PMSP, SPF).

Pilea microphylla apresenta distribuição tropical e subtropical, apresentando maior diversidade na Ásia e América do Sul (Monro, 2006). No Brasil é frequentemente abundante na maioria dos ambientes rochosos da Cadeia do Espinhaço, especialmente em afloramentos de calcários, podendo ocorrer também em ambientes concretados ou em paredes rochosas. 
São comumente encontradas em florestas úmidas de terras baixas, em florestas semidecidual associadas à solos residuais a partir de rochas ácidas e calcárias. $\mathrm{Na}$ Serra do Cipó ocorre principalmente em matas decidual associadas a afloramentos de calcários, sendo muito comum no alto dos afloramentos de calcários do Grupo I e II da Área de Proteção Ambiental Morro da Pedreira.

Estudos em floras regionais, como por exemplo, na Guiana Venezuelana (Pool, 2005) P. microphylla tem sido frequentemente confundida com $P$. serpyllacea (Kunth) Liebm. Esta espécie é muito similar àquela na aparência, mas difere por ter folhas subglobosas e simétricas no mesmo nó e por apresentar inflorescências pistiladas com pedúnculos tão longo quanto às folhas subtendidas. Pode também ser confundida no aspecto geral com algumas espécies do gênero Chamaesyce Gray (Euphorbiaceae), ambos ocorrentes no mesmo ambiente de áreas alteradas, mas estas são plantas lactescentes.

Suas flores e frutos são frequentemente encontrados o ano todo, principalmente de janeiro a março.

\section{Pourouma Aubl.}

Árvores ou arvoretas, frequentemente com raíz-suporte; ramos geralmente odoríferos; seiva escassa, alva a avermelhada, tornando-se enegrecida quando exposta ao ar; denso indumento aracnóide com tricomas de diferentes comprimentos, marromferrigíneo. Folhas basifixas, inteiras ou palmadas, às vezes 3-11(-13)-lobadas, com grande variação na forma e textura ao longo dos estágios desenvolvimento, ovada a elíptica ou oblonga a obovada, cartácea a subcoriácea ou coriácea; indumento esparso a denso; venação semicraspedódroma a broquidódroma nas folhas inteiras, actinódroma nas folhas lobadas ou partidas; margem inteira, às vezes levemente crenada; estípulas amplas, às vezes curtas, conatas e completamente amplexicaules, decíduas deixando cicatrizes horizontais ou raramente persistentes; cistólitos ausentes na lâmina. Inflorescências aos pares, axilares, ramificadas, geralmente dicotômicas a raramente tricotômicas, às vezes não ramificadas; brácteas lineares, basais, geralmente diminutas, às vezes ausentes; inflorescências estaminadas em capítulos globosos; inflorescências pistiladas em fascículos (subumbeladas) ou flores isoladas. 
Flores estaminadas: sésseis ou pediceladas; perianto com 3-4-tépalas, livres, basalmente conatas ou às vezes inteiramente fusionadas, urceolado ou infundibuliforme; estames 2-4, livres; anteras exsertas antes da antese; filetes livres ou conatos ao perianto; pistilódio reduzido. Flores pistiladas: isoladas, levemente fasciculadas, pediceladas; perianto tubular, inteiro ou 4-3-lobulado; estilete curto; estigma sub-peltado a peltado. Fruto drupa, relativamente grande; pericarpo seco, endocarpo crustáceo, envolto pelo perianto acrescente formando uma pseudodrupa; sementes sem endosperma; cotilédones grandes.

Este gênero compreende 27 espécies arbóreas de médio tamanho ocorrentes em áreas de florestas úmidas da América do Sul e Central (Berg \& Simonis, 2000). Na Serra do Cipó ocorre apenas uma espécie - $P$. guianensis Aubl.

Um grande número de espécies de Pourouma apresenta ampla distribuição, e todas essas espécies estão presentes na Bacia Amazônica e nas Guianas. Berg et al. (1990) definem três centros de diversidade no gênero: Bacia Amazônica Superior (maioria dos taxa concentrados no norte-nordeste desta região); Região das Guianas ou Bacia Amazônica Inferior (no Brasil: leste do Pará e Amapá) e a Região Costal do Pacífico (Colômbia e Equador, estendendo-se até a Guatemala e Norte da Venezuela). As populações do leste brasileiro como $P$. guianensis Aublet, $P$. mollis Trécul e $P$. velutina Mart. ex Miq. estão estreitamente relacionadas com as espécies da Bacia Amazônica Inferior e parte das Guianas.

Pourouma foi estabelecido por Aublet em 1775 quando foi descrita a espécie $P$. guianensis. Desde então muitas outras espécies foram descritas por autores como Martius (1843), Trécul (1847), Klotzsch (1847), Miquel (1853), Rusby (1910), Benoist (1922, 1924), Macbride (1930), Ducke (1932a, 1932b, 1947), Standley (1937b), Cuatrecasas (1954, 1956a, 1956b, 1956c, 1967), Woodson \& Schery (1960) e finalmente por Berg \& Kooy (1982), Berg \& van Heusden (1988) e Berg (1989 e 1990).

$O$ gênero tem sido tratado também em floras regionais neotropicais, como: Peru (Macbride, 1937), Panama (Woodson \& Schery, 1960), Costa Rica (Burger, 1977), Suriname (Berg, 1975), llha do Barro Colorado (Croat, 1978) e mais recentemente na Venezuela (Berg \& Simonis, 2000). 
Pourouma geralmente apresenta correlações entre seus caracteres morfológicos. Exemplos dessas correlações podem ser observados na morfologia foliar. Espécies com folhas lobadas apresentam consideráveis diferenças na sua textura, dimensão e incisão da lâmina entre os materiais juvenis e adultos. Em espécimes juvenis as incisões tendem a ser mais profundas e numerosas, enquanto nos ramos de indivíduos adultos as folhas são menos profundas e inteiras. Da mesma forma, taxa com folhas lobadas tendem a apresentarem lâminas largas, frequentemente subcoriáceas e densamente vilosas, pecíolos e estípulas longos. Por outro lado, taxa com folhas inteiras tendem a apresentarem lâminas de médio tamanho, geralmente coriácea e esparsamente vilosa, curtos pecíolos e estípulas pequenas (Berg et al., 1990).

Segundo Berg et al. (1990) Pourouma (assim como o gênero africano Myrianthus P. Beauv.) apresenta vários caracteres, especialmente vegetativos, que demonstram um estágio intermediário entre Cecropia (tal como seu correspondente africano Musanga C.Sm. ex R.Br.) e Coussapoa (igualmente ao seu semelhante malasiano Poikilospermum Zipp. ex Miq.). Pourouma demonstra maior similaridade morfológica com Myrianthus do que com os demais gêneros de Urticaceae. As similaridades são observáveis tanto no hábito, na forma e dimensões foliares, quanto no pecíolo e nas inflorescências estaminadas.

Pouco é conhecido sobre o sistema de polinização em Pourouma. No entanto, aspectos morfológicos de suas inflorescências e flores, assim como de seu hábito (árvores de pequeno a médio tamanho em florestas) sugerem a ocorrência de anemofilia. Contudo, Falcão \& Lleras (1980) registraram um grande número de espécies de abelhas como polinizadores de $P$. cecropiifolia Mart. Essas abelhas coletavam pólen nas inflorescências estaminadas e carreavam para as pistiladas. Porém esses autores não demonstraram possíveis fatores de atração das inflorescências pistiladas para as abelhas.

Assim como espécies de Cecropia, algumas espécies de Pourouma - $P$. formicarum Ducke e P. myrmecophila Ducke - apresentam mirmecofilia. Essas espécies apresentam dilatações (domácias) na base do pecíolo, que frequentemente encontram-se habitadas por formigas. De acordo com Benson (1985) essas formigas 
pertencem ao gênero Allomerus e, provavelmente, alimentam-se de corpos protéicos produzidos na face abaxial da domácia.

Importância econômica tem sido dada aos frutos de $P$. cecropiifolia Mart., os quais são frequentemente utilizados para o consumo humano. Em algumas áreas amazônicas são atribuídos nomes vernaculares a essas espécies, como por exemplo, imbaúba do vinho e uvilha, em referência ao seu cultivo para a produção de vinhos doces (Falcão \& Lleras, 1980).

5.1. Pourouma guianensis Aublet, Hist. pl. Guiane 2: 892, t. 341. 1775.

Nome vernacular: mangabé, guarumo, itararanga (SP, Crestana et al., 2006); itararanga e tararanga branca (BA), Kaymbe'y ou Ka'apor (MA), imbaubarana e imbaúba torém (MT), amapati ou mapati (PA), imbaubarana e pau de jacu (PR), embaúba da mata (PE) (Berg et al., 1990).

Figura 12: $L-P$.

Árvores 6-30 m alt., ramos espessos, 3-15 mm diâm., fistulosos, desfolhados exceto próximo ao ápice, alvos a ferrugíneos, ou amarelados a marrons, hirtelos a pubérulos ou hirsutos a levemente tomentosos, às vezes com tricomas diminutamente papilosos, dourados, vilosos; lenticelas rugosas e em raios horizontais; estípulas decíduas, pubescentes a hirsutas, amareladas, deixando cicatriz horizontal. Lâmina foliar 3-5(-7)-partida ou lobada, (8,5-)10,3-20,4(-45,6) cm compr., (8,5-)10,3-20,4(-45,6) cm larg., ou inteira (-3-lobada), (3,5-)10,3-15,8(-20,6) cm compr., (2,2-)3,4-5,6(-14,5) cm larg., amplamente ovada a elíptica, às vezes oblonga, cartácea a subcoriácea, espiralada; ápice acuminado; base cordada a truncada, às vezes arredondada a levemente aguda; face adaxial escabra, esparso hirsuta levemente tomentosa, hirtela a hirsuta sobre a nervura principal, indumento aracnóide confinado em aréolas; face abaxial tomentosa a levemente vilosa ou hirtela, pubescente ao longo das nervuras laterais, indumento aracnóide confinado em aréolas, macia ao toque; margem inteira a levemente sinuosa; venação actinódroma, nervuras laterais (6-)12-20 pares, impressa na face adaxial e proeminente na abaxial; pecíolo (5,5-)10,2-17,5 (-20,4) cm compr., pubérulo a hirtelo ou denso a esparsamente hirsuto, alvo-amarelado a marromavermelhado; estípulas $(2,5-) 6,4-9,3(-12,4)$ cm compr., pubérulas a hirtelas ou 
tomentosas a levemente vilosas, alvo-amareladas a levemente douradas, internamente glabras ou com esparsos tricomas alvo-amarelados. Inflorescências estaminadas: cimeiras pedunculadas, patentes, (2,6-)3,5-4,6(-8,0) cm diâm.; pedúnculo (3,3-)4,2-6,7($8,4) \mathrm{cm}$ compr., alvo-amarelado a marrom-ferrugíneo, levemente dourado, pubérulo a hirtelo ou levemente hirsuto a viloso; flores estaminadas glomerulares ou isoladas, terminais, sésseis ou pediceladas; perianto com (3-)4-tépalas, $(0,8-) 1,2-1,6(-1,8) \mathrm{mm}$ compr., basalmente conatas, livres no ápice, lanceoladas, pubescentes; estames 3-4; filetes delgados, enegrecidos, (1,1-)1,5-1,8(-2,1) mm compr., menores que o perianto; anteras rimosas, 0,3-0,6 mm compr., elípticas, amareladas. Inflorescências pistiladas: cimeiras, pedunculadas, patentes, (3,5-)4,7-6,2(-9,5) cm diâm.; pedúnculo (3,4-)6,5$9,6(-12,4) \mathrm{cm}$ compr., alvo-amarelado a marrom, levemente dourado, hirtelo ou levemente hirsuto a viloso; flores pistiladas pediceladas, 5-25 flores; perianto com (3-)4tépalas, (2,5-)3,8-4,3(-5,0) mm compr., (1,7-)2,7-3,5(4,0) mm larg., levemente viloso a esparsamente puberuloso, alvo a amarelado, dourado, ovóide, tubular com pequena abertura no ápice; pedicelos (0,3-)0,6-1,2(-1,8) cm compr., na frutificação $(0,6-)$ 1,1-1,8(2,8) cm compr.; estigmas (0,6-)1,3-2,0(-2,5) mm diâm., sub-peltados, levemente vilosos a hirsutos. Drupas ovóides a elipsóides envolvidas pelo perianto amplo e acrescente, $(1,2-) 1,5-1,8(-2,5) \mathrm{cm}$ compr., frequentemente vilosas, às vezes esparso-puberulas, raramente glabras. Sementes ca. 1,0 cm compr.

Material examinado: Minas Gerais, Itambé do Mato Dentro, distrito de Santana do Rio Preto (Cabeça de Boi), na Mata do Cachoeirão, 19²5'54.7"S 4325'58.3"W, M.F. Santos \& L.M. Borges 216, 18.XII.2007, fl. (SPF); 19²5'51.0"S 43ํ25'57.8"W, M.F. Santos \& H.F. Serafim 234, 13.III.2008, fl. (SPF).

Material adicional: Amazonas, Manaus, $90 \mathrm{~km}$ nordeste de Manaus, mata de terra firme, 2024'26”'S 5945'40"W, alt. 50-125 m, A.A. Oliveira et al. 522, I.1993, fr. (INPA, NY, SPF); A.A. Oliveira et al. 1074, III.1993, fr. (INPA, NY, SPF). Bahia, Itamarajú, Fazenda Nova Pau-Brasil, 4 km a Norte da junção da BR-101 com a estrada para Prado, 1655'S 39³5'W, J. Kallunki et al. 580, 18.II.1994, fr. (NY, SPF). Minas Gerais, Muriaé, beira da BR 116, Fazenda Barro Alegre, próximo ao Córrego Barro Alegre, em floresta pluvial tropical atlântica, J.R. Pirani et al. 2524, 23.X.1989, fl. (MBM, SP, SPF). São Paulo, Pariquera-Açu, Estação do IAC, mata atlântica de planície, 4753'06”S 2436'30"W, L. Sakai et al. 33375, 10.Il.1995, fl., fr. (IAC, SPF, UEC); 
Ubatuba, Parque Estadual da Serra do Mar - Núcleo Picinguaba, Trilha do Corisco, V. Kurt 13, 25.II.1992, fl. (SPF).

Ocorre da Bacia Amazônica ao leste brasileiro, estendendo-se até o leste da Colômbia e região das Guianas. Geralmente apresenta distribuição restrita a baixas altitudes, embora haja registros para 1300 m na Venezuela e 1500 m na Bolívia (Berg \& Simonis, 2000). Na região Norte e Centro-Oeste há registros nos estados do Acre, Amazonas, Roraima, Rondônia e Mato Grosso e ocorrência disjunta no leste brasileiro, desde Pernambuco até Santa Catarina, principalmente em florestas estacionais não susceptíveis a ocorrências de inundações, embora, às vezes sejam encontradas espécimes de $P$. guianensis em áreas de várzeas.

Berg (2000) reconhece duas subespécies de $P$. guianensis: $P$. guianensis subsp. guianensis e P. guianensis subsp. venezuelensis (Cuatrec.) C.C. Berg \& Heusden. Na Cadeia do Espinhaço, assim como ao longo de florestas semidecidual do leste brasileiro, a subespécie mais comum é $P$. guianensis subsp. guianensis. Esta tem sido frequentemente encontrada na face leste da Serra do Cipó, em florestas estacionais semidecidual ocorrentes no distrito de Santana do Rio Preto.

Pourouma guianensis tem sido frequentemente confundida com P. bicolor Mart., tanto em identificações no campo quanto em exsicatas depositadas nos herbários, levando muitas vezes a determinações errôneas. De fato, esses dois taxa compartilham vários caracteres e exibem sobreposição em sua distribuição geográfica. Berg et al. (1990), no entanto, tem destacado três características do indumento que auxiliam na distinção destas duas espécies: 1) indumento da face abaxial das estípulas - glabro em $P$. guianensis e denso tricomas alvo-amarelado em $P$. bicolor; 2) indumento das nervuras laterais na face abaxial - em $P$. guianensis os tricomas são relativamente longos e patentes, enquanto em $P$. bicolor são menores não apresentam distinção entre nervuras laterais e principal; e 3) proeminência das nervuras e ocorrência de indumento aracnóide na face abaxial - $P$. guianensis apresenta nervuras proeminentes e indumento aracnóide em auréolas, e nervuras impressas e indumento aracnóide sobre as nervuras laterais em $P$. bicolor. 
Sua importância econômica está relacionada à utilização dos frutos para alimentação de pássaros e ao uso ornamental, principalmente devido ao formato de suas folhas, inflorescências e frutos (Crestana et al., 2006). 


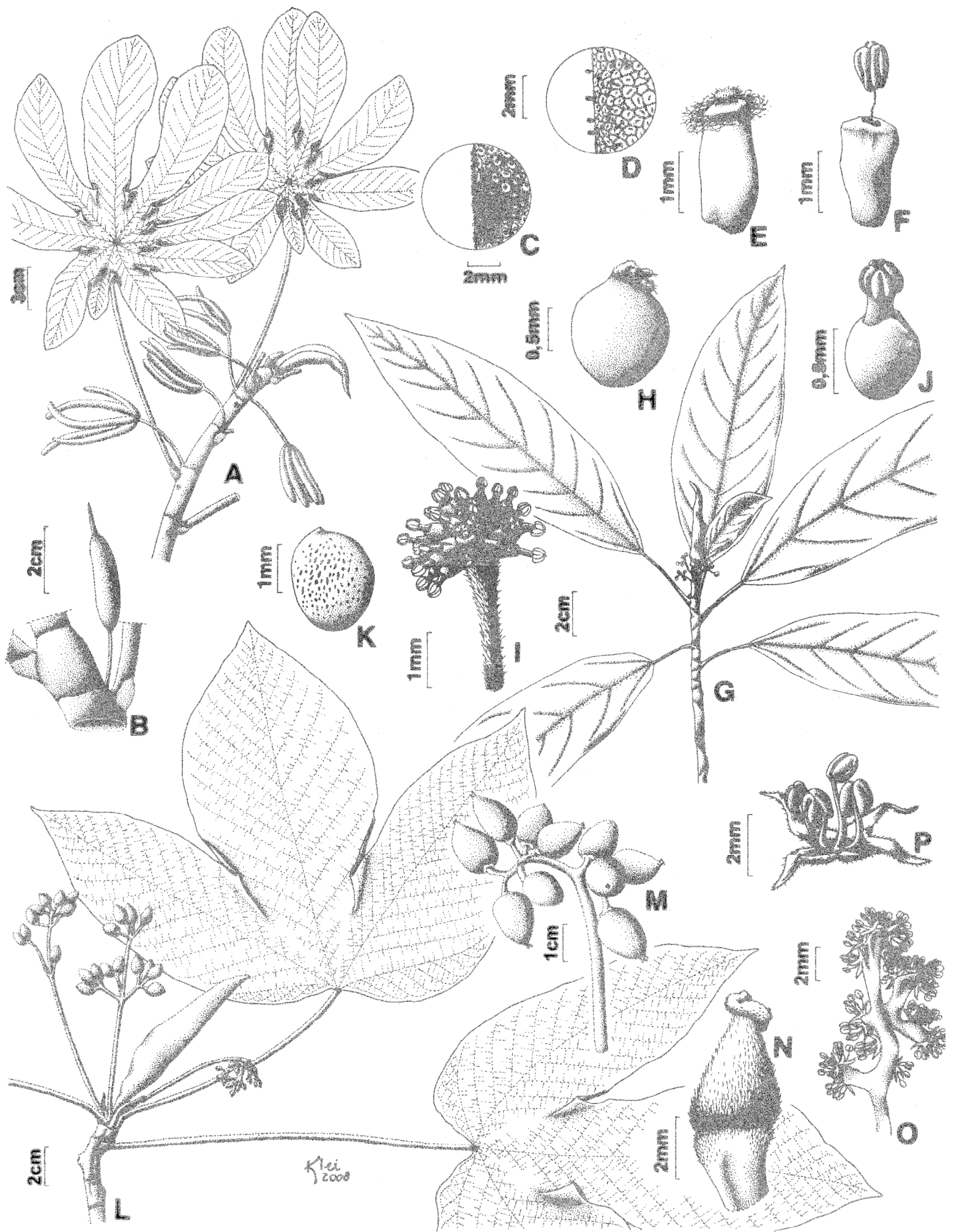

Figura. 12. A-F. Cecropia pachystachya. A. Ramo fértil. B. Detalhe mostrando triquílio na base do pecíolo e espata. C. Detalhe da inflorescência pistilada. D. Detalhe da inflorescência estaminada. E. Flor pistilada e indumento aracnóide. F. Flor estaminada e estame. G-K. Coussapoa microcarpa. G. Ramo fértil. H. Flor pistilada. I. Inflorescência estaminada. J. Flor estaminada. K. Fruto. L-P. Pourouma guianensis. L. Ramo fértil. M. Fruto. N. Flor pistilada. O. Inflorescência estaminada. P. Flor estaminada. A-C: Martins et al. 110. D e F: Martins et al. 69. E: Pirani et al. CFSC 11479. G: Santos \& Serafim 269. He K: Santos \& Serafim 293. I e J: Leoni 1037. L-N: Santos \& Borges 216. O e P: Kurt Lo 13. 


\section{Urera Gaudich.}

Arbustos, arvoretas a subarbustos, até $6 \mathrm{~m}$ alt., ramos tortuosos, escandentes, fistulosos, sulcados a canaliculados, verde-amarelados, tornando-se enegrecidos na porção distal, glabros a esparsamente sub-hispidulosos; acúleos presentes, reduzidos, raramente ausentes; tricomas urticantes geralmente presentes, decíduos. Folhas alternas, basifixas, inteiras a raramente lobadas, amplamente ovadas a elípticas, membranáceas, cartáceas a subcoriáceas; venação actinódroma a semicraspedódroma, raramente broquidódroma; margem denteada a sinuado-serreada; cistólitos lineares, puntiformes, sobre ou próximas às nervuras; estípulas intrapeciolares, fusionadas. Inflorescências axilares, cimosas, dicotômicas ou irregulares, escorpióides, unissexuadas (plantas estritamente dióica); flores estaminadas monoclamídeas; perianto 4-5-partido ou lobado, tépalas eretas; estames isômeros, unidos às tépalas; flores pistiladas: perianto 4-tépalas, livres, fusionadas na base, assimetricamente pareadas; ovário ovóide, unicarpelar, unilocular. Aquênio ovóide a elíptico, achatado, raramente dilatado, crescimento reto ou oblíquo, às vezes acrescente a um perianto carnoso.

O gênero Urera Gaudich. apresenta cerca de 35 binômios publicados, ocorrentes na região tropical da América e da África e Madagascar (Friis, 1993). Mas assim como outros membros de Urticaceae, mostra-se pouco conhecido, sendo raros os trabalhos que o enfocam, principalmente com enfoque taxonômico ou ecológico.

No estado de Minas Gerais, espécies de Urera Gaudich. frequentemente formam densas populações na orla de matas decidual, semidecidual, capoeiras e matas ciliares de áreas elevadas da Cadeia do Espinhaço (Brandão, 1996). Por meio de análise de material de herbários tem sido verificados registros de Urera em vários municípios mineiros situados no domínio do cerrado, de capões de mata e de campos rupestres.

Em estudo sobre a flora de áreas erodidas de calcário Bambuí no estado da Bahia, Andrade-Lima (1977) verificou a ocorrência de populações de Urera restritas a um condicionamento edáfico formado por calcários desnudados e com mínima capacidade de retenção hídrica da superfície. 
As espécies nativas de Urera geralmente são conhecidas como 'urtigas' ou 'urtigões'. Seus tricomas são frequentemente maiores que os de outras espécies e dotados de uma projeção angular, apresentando em seu ápice agudo uma solução líquida transparente contendo ácido fólico. Quando tocado, o extremo dessa estrutura se abre e sua pressão injeta o líquido no interior da pele, causando dores agudas que vão desde poucos minutos até várias horas (Little Jr, et al., 1988). Entretanto, as injúrias causadas por esses contatos não são permanentes, podendo ocorrer, apenas, em casos extremos, erupções ou bolhas na pele, inchaço, febre ou úlcera (Allen, 1943).

6.1. Urera baccifera (L.) Gaudichaud, Bot. Voy, Uran: 496. 1826.

Nome vernacular: urtiga-branca (MG, Rocha, C.A., BHCB 5598), cansanção (MG, Andrade, P.M., BHCB 7788); urtiga vermelha (MG, Gavilanes \& Brandão, 1994); urtiga-grande (MG, Brandão \& Brandão, 1995); urtiga brava, urtiga graúda, urtiga de cipó (Brasil, Little Jr, et al., 1988).

Figura 13: $\mathrm{H}-\mathrm{K}$.

Arbustos, subarbustos ou arvoretas, $1,5 \mathrm{~m}$ a $5,5 \mathrm{~m}$ alt., ramos tortuosos, escandentes, fistulosos, sulcados a levemente canaliculados, acinzentados a verdeamarelados, glabros a raramente hispidulosos; acúleos presentes na base e inermes no ápice, reduzidos, raramente ausentes; tricomas urticantes geralmente presentes, decíduos; látex escasso, tornando-se enegrecido quando exposto ao ar. Lâmina foliar $(3,8-) 8,5-16,7(-25,8) \mathrm{cm}$ compr., (3,8-)5,5-13,3(-18,7) cm larg., amplamente ovada, às vezes ovada a levemente elíptica, membranácea a subcoriácea ou cartácea; ápice acuminado a agudo, base frequentemente cordada a subcordada, às vezes arredondada a levemente truncada, margem sinuada a serreada ou denteada; face adaxial esparsamente híspida a hispidulosa, áspera ao toque, concreções de carbonato de cálcio geralmente presente, puntiforme, esbranquiçado; face abaxial esparsa a densamente híspida; acúleos 1,7-2,5 mm compr. ao longo das nervuras na face adaxial e na principal da face abaxial; venação actinódroma, às vezes craspedódroma; cistólitos arredondados ou lineares sobre ou próximas às nervuras; pecíolos (2,3-)5,712,3(-18,4) cm compr., sulcados, fistulosos, rugosos, pubescentes, com acúleos 
pequenos; estípulas (1,8-)2,4-3,0(-3,5) cm compr., triangulares, decíduas, pubescentes. Inflorescências axilares, cimosas ou paniculadas, dicotômicas ou escorpióides, ramificadas, rosadas; estaminadas $(3,2-) 3,6-4,0(-5,0) \mathrm{cm}$ compr., pistiladas (1,5-)2,03,0(-5,0) cm compr.; pedúnculo curto, densamente pubescente. Flores estaminadas: (1,3-)1,7-2,2(-3,0) mm compr., (1,2-)1,5-1,8(-2,1) mm larg., levemente globosas, às vezes comprimidas, alvo-rosadas, pediceladas; perianto com 5-tépalas, (1,1-)1,3-1,8(2,0) mm compr., (0,4-)0,7-1,0(-1,3) mm larg., elípticas a agudas; pedicelo 0,4-0,6 mm compr.; estames 5, (2,2-)3,0-4,5(-5,3) mm compr., exsertos, dobrados no botão, alvos a amarelados; anteras 0,7-1,0 mm compr., rimosas, amareladas; pistilódio (0,4-)0,7-1,0(1,3) $\mathrm{mm}$ compr., discóide a levemente elíptico, ápice globoso, enegrecido. Flores pistiladas: (1,4-)1,8-2,3(-3,1) mm compr., $(0,5-) 0,7-1,3(-2,0) \mathrm{mm}$ larg., levemente globosas; perianto com 4-tépalas, (0,5-)0,8-1,0(-1,2) mm compr., (0,3-)0,5-0,8(-1,0) mm larg.; ovário (0,4-)0,7-1,0(-1,3) mm compr., 0,4-0,6 mm larg., levemente cilíndrico a elíptico; estilete curto, impregnado de concreções carbonáticas; estigma capitado, penicelado, ferrugíneo a arroxeado. Aquênio globoso a levemente achatado, (2,2-)2,83,2(-3,6) mm compr., (0,3-)0,6-0,8(-1,2) mm larg., perianto acrescente, assimétrico, estigma persistente, amarelo a alaranjado; semente (1,0-)1,2-1,7(-2,0) mm compr., ferrugínea a alaranjada na base, ápice enegrecido a avermelhado, endosperma presente.

Material examinado: Minas Gerais, Cardeal Mota, Serra do Cipó, APA Morro da Pedreira, alto dos afloramentos de metacalcário (blocos do Grupo I), floresta decidual, 19¹8'19.3”S 4336'50.0”W, alt. 920 m, E.G.A. Martins et al. 53, 17.I.2007, fl. fr. (SPF); Santana do Riacho, ao longo da rodovia Belo Horizonte - Conceição do Mato Dentro: km 133, em mata mesófila, M.C. Amaral et al. CFSC 7137, 2.III.1981, fl. (ICN, SPF); M.C. Amaral et al. CFSC 7140, 2.III.1981, fl., fr. (ICN, SP, SPF); Serra do Cipó, Morro da Pedreira, mata calcária, J.A. Freire s.n., 21.IV.1989, fr. (BHCB 17602)

Material adicional: Bahia, Palmeiras, rodovia Lençóis-Seabra, ca. $21 \mathrm{~km}$ nordeste de Lençóis, próximo ao Rio Mucugezinho, 122ㄱ'27"S 4127'10"W, alt. 900-1100 m, R.M. Harley et al. CFCR 14170, bt., fl. (NY, SPF). Minas Gerais, Bocaiúva, Engenheiro Dolabela, BR 135, à 51 $\mathrm{km} \mathrm{N}$ do trevo para Buenópolis, afloramentos de calcários na estrada para Eng. Dolabela, 17³0'S 4400'W, J.R. Pirani et al. 3857, 10.I.1998, fl. (SPF); Lagoa Santa e Matozinhos, na APA Carste de Lagoa Santa, na Fazenda Caucaia, A.E. Brina \& L.V. Costa s.n., 27.III.1995, fl., 
fr. (BHCB 36581); Matozinhos, na APA Carste de Lagoa Santa, A.E. Brina \& L.V. Costa s.n., 27.III.1995, fr. (BHCB 36583); Diamantina, estrada para Curralinho, Gruta do Salitre, M.L.O. Trovó \& M.T.C. Watanabe 388, 21.IV.2007, fl., fr. (SPF); Joaquim Felício, estrada pela Serra do Cabral, L.Rossi et al. CFCR 1086, 17.IV.1981, fl. (SP, SPF); Paius, afloramentos de rochas calcárias, M.A. Rollo s.n., 23.I.1991, bt., fl. (SP, SPF 168364); Patrocínio, Serra do Salitre, mata ciliar do Rio Salitre, G. Ceccantini 311, 24.III.1994, fr. (SPF). Paraná, Sete Quedas, M.R.F. Melo 389, 20.III.1982, fr. (SP, SPF). São Paulo, Bauru, Reserva Estadual de Bauru, J.Y. Tamashiro et al. 173, 26.V.1994, fr. (IAC, SPF, UEC); São Paulo, Cidade Universitária "Armando de Salles Oliveira" - USP, Instituto de Biociências, atrás do Anfiteatro do Departamento de Zoologia,

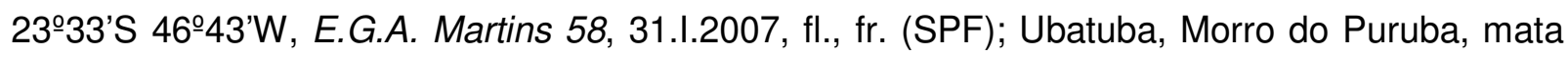
degradada de encosta, A.C.E. Pontes et al. 29800, 21.VIII.1996, bt., fl. (SPF, UEC).

Urera baccifera (L.) Gaudich. apresenta distribuição desde o México, passando pela América Central e Antilhas, até o sul do Brasil, Argentina, Bolívia e Peru (Little Jr, et al., 1988). É comumente encontrada em florestas úmidas de terras baixas com precipitações pluviométricas acima de $1600 \mathrm{~mm}$, em áreas drenadas, matas ciliares e em florestas semidecidual associadas a solos residuais a partir de rochas ácidas e calcárias. Na Serra do Cipó ocorre em capões de mata, na orla ou interior de matas decidual associadas a afloramentos de calcários, sendo muito comum na Área de Proteção Ambiental Morro da Pedreira.

Em estudo sobre as florestas estacionais decidual a oeste da Cadeia do Espinhaço, Meguro et al. (2007) identificaram U. baccifera (L.) Gaudich. em três das cinco áreas de afloramentos de calcários do estudo, caracterizando-a como espécie oportunista de orla de florestas primárias ou perturbadas. Segundo Bertoni et al. (1988) trata-se de espécie pioneira, geralmente presente em áreas perturbadas e, no Brasil, tem sido utilizada como indicadora de áreas degradadas.

Nascimento et al. (1999) verificaram o surgimento de populações de U. baccifera em áreas com histórico de queimadas na Mata Atlântica do sudeste brasileiro. Essas populações apresentavam ainda altas taxas de recrutamento e baixa de mortalidade.

A análise dos materiais de $U$. baccifera geralmente mostra grande variação morfológica no tamanho das folhas e na presença ou não de acúleos, dificultando, às vezes a sua correta determinação. 
Na América Central essa espécie tem sido cultivada para formar cercas-vivas e cercados, que devidos aos seus acúleos e tricomas urticantes, tornam-se uma barreira impenetrável (Little Jr, et al., 1988). Já no México, ainda durante o Império Inca, os Aztecas e os índios Otomi utilizavam o caule de urtiga-brava na fabricação de papel (Hagen, 1943). Mais recentemente, tem sido cultivada como erva em plantações de café na Bolívia, objetivando a obtenção de sombra (Francis \& Rodríguez, 1993).

O fruto de $U$. baccifera, dotado de um cálice acrescente, carnoso e colorido, mostra-se atrativo para aves, que parecem atuar como eficientes dispersores de suas sementes (Barroso et al., 1999). 


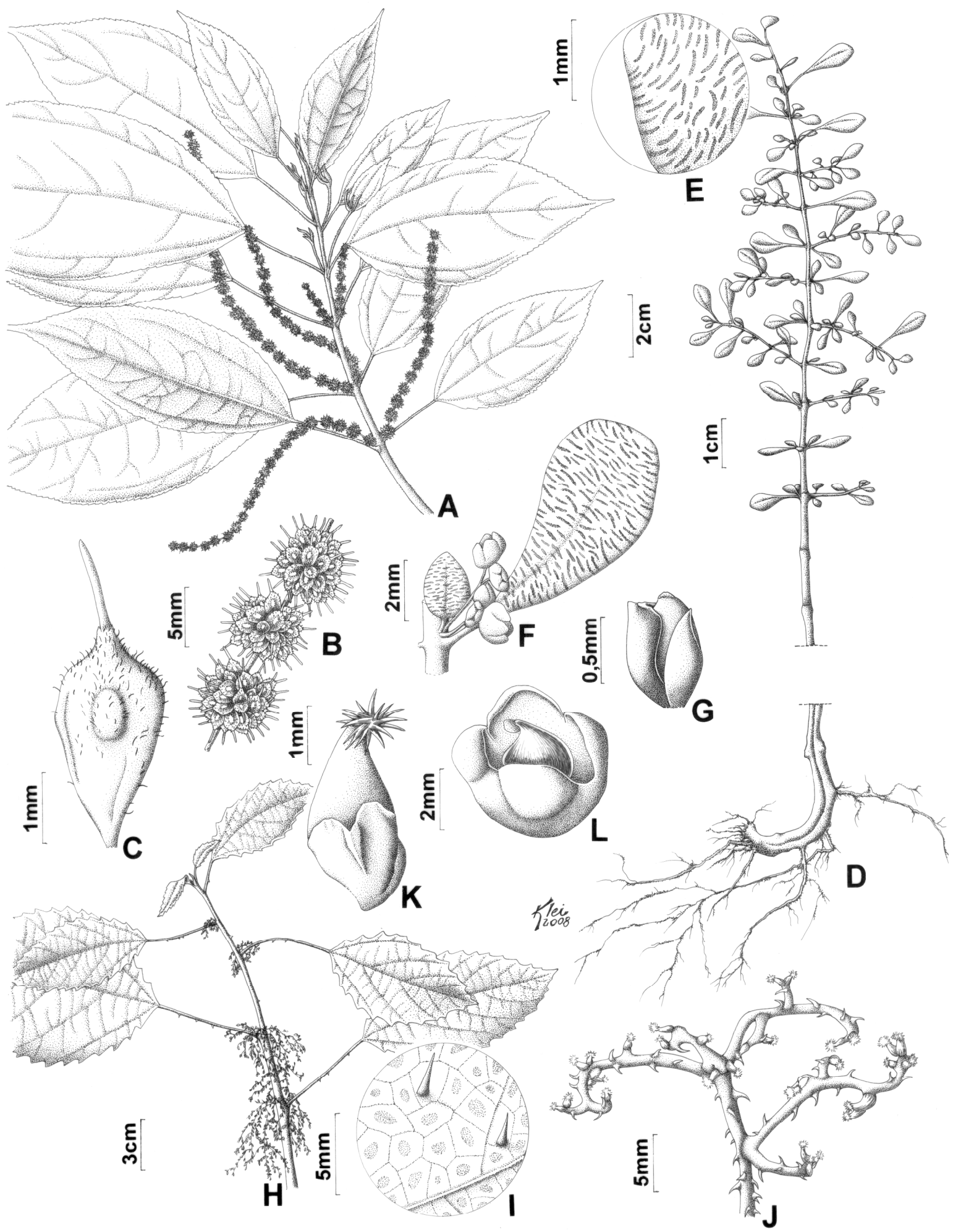

Figura 13. A-C. Boehmeria caudata. A. Ramo fértil. B. Detalhe de ramo frutífero. C. Fruto. D-G. Pilea microphylla. $D$. Raiz e ramo fértil. E. Detalhe da face adaxial da folha mostrando os cistólitos. F. Detalhe de ramo florífero. G. Flor pistilada. H-K. Urera baccifera. H. Ramo fértil. I. Detalhe da face adaxial da folha. J. Detalhe de ramo florífero. K. Flor pistilada. L. Fruto. A-C: Furlan et al. CFSC 6965. D e E: Martins et al. 54. F e G: Martins et al. 107. $\mathrm{H}-\mathrm{L}:$ Martins et al. 53. 


\section{CONSIDERAÇÕES FINAIS E CONCLUSÕES:}

O presente estudo taxonômico das espécies do clado urticóide ocorrentes na Serra do Cipó contribui para o melhor conhecimento da flora dessa região, não só por incrementar o número de gêneros e espécies registrados ali, mas também por trazer aprimoramento sobre o conhecimento acerca desses táxons. No total foram levantadas 20 espécies em 15 gêneros, distribuídas nas famílias Cannabaceae, Moraceae e Urticaceae. Assim, das famílias pertencentes ao clado urticóide, apenas Ulmaceae ficou sem representante na Serra do Cipó, uma vez que as duas espécies desse grupo citadas no checklist de Giulietti et al. (1987), Celtis pubescens e Trema micrantha, passaram a ser agora tratadas em Cannabaceae. No entanto, não se exclui a possibilidade de coleta futura de alguma espécie de Ulmaceae na Serra do Cipó, pois táxons como Ampelocera glabra Kuhlm. e Phyllostylon brasiliense Capan. ex Benth. \& Hook. f. têm ocorrência registrada em diversas áreas do centro do estado de Minas Gerais.

Comparando com o checklist anterior (Giulietti et al., 1987), o presente trabalho trouxe um aumento de quase $50 \%$ no total de espécies e gêneros amostrados na área de estudo, passando de oito para 15 gêneros e de 11 para 20 espécies registradas. Dentre as famílias urticóides, Moraceae apresentou a maior diversidade (sete gêneros e 11 espécies), constituindo um aumento de quatro gêneros e cinco espécies em relação ao checklist, seguida de Urticaceae (seis gêneros e sete espécies, aumento de três gêneros e quatro espécies) e por fim Cannabaceae (dois gêneros e as mesmas duas espécies tratadas anteriormente em Ulmaceae).

Esse acréscimo no número de espécies pode-se atribuir a três fatores:

1) Aumento da área amostrada: tradicionalmente, a maioria das coletas na Serra do Cipó concentravam-se nas áreas circunvizinhas ao longo da Rodovia MG-010. A partir dos anos 90, com a consolidação da infra-estrutura do Parque Nacional, pôde haver uma expansão considerável das regiões exploradas, passando-se a realizar coletas na Serra das Bandeirinhas, Cânion do Córrego Mascate, Capão dos Palmitos e Cachoeira da Farofa. Porém, mesmo assim foi só mais recentemente que muitas áreas mais a oeste e ao sul da serra passaram a ser amostradas mais regularmente. No presente 
trabalho foram realizadas algumas expedições à face leste da Serra do Cipó, abrangendo parte do município de Itambé do Mato Dentro, até então muito pouco visitada. Foi de áreas desse município, como o distrito de Santana do Rio Preto, na região chamada Cabeça de Boi, que adveio grande parte das urticóides arbóreas reportadas neste trabalho, como Ficus gomelleira, Helicostylis tomentosa, Pourouma guianensis, Cecropia hololeuca e Maclura tinctoria.

2) Esforço de coleta: além da realização de expedições à novas áreas da Serra do Cipó, incursões efetuadas à áreas ao longo da Rodovia MG-010, especialmente nos pontos de coletas das espécies amostradas no checklist, permitiram a obtenção de abundante material fértil e a confirmação dessas espécies amostradas, além de alguns novos registros para a Serra do Cipó. Além disso, permitiram ainda a apreciação dos tipos de habitats preferenciais das espécies amostradas, a observação dos hábitos e algumas variações relacionadas ao ambiente.

3) Consultas aos herbários: outro fator de importância fundamental para o aumento das urticóides da Serra do Cipó, foi a verificação detalhada das coleções presentes nos principais herbários com materiais oriundos dessa região e daqueles com rica coleção do grupo estudado. Essa atividade resultou na inclusão de Brosimum gaudichaudii, Dorstenia brasiliensis e Ficus obtusiuscula, com coletas até anteriores ao checklist, mas que não constavam no mesmo.

Dessa maneira, verifica-se que a realização de expedições exploratórias em novas áreas e de consultas a herbários são métodos fundamentais para o conhecimento da biodiversidade florística de determinado espaço geográfico. Não obstante, a amplificação desses fatores serve como uma atualização dessa biodiversidade, conferindo aos projetos florísticos um aspecto cíclico em constante atualização de seus elementos.

$\mathrm{Na}$ Serra do Cipó, duas áreas de coleta se destacaram por apresentar maior diversidade urticóide, tanto nos aspectos qualitativo como quantitativo. A primeira 
destas, a Floresta Estacional Decidual da APA Morro da Pedreira, destacou-se por apresentar exemplares exuberantes de figueiras da espécie Ficus calyptroceras, com suas longas raízes crescendo sobre e entre as fendas das enormes rochas carbonáticas que caracterizam esse afloramento situado ao pé da Serra do Cipó. Essa área é marcada ainda pela concentração de espécies de Cannabaceae (Celtis iguanaea e Trema micrantha) como árvores da mata, de Urticaceae (com abundantes agrupamentos de Pilea microphylla sobre as faces expostas das rochas e arbustos de Urera baccifera). A segunda área foi a região de Floresta Estacional Semidecidual da face leste da serra, cuja exploração resultou, como citado anteriormente, em expressivo aumento de espécies arbóreas desse grupo no trabalho. Não obstante, ambientes de mata ciliar também apresentaram grande ocorrência de espécies urticóides.

Assim, visualizam-se as preferências ambientais das urticóides divididas em três grupos principais dos cinco habitats de ocorrência reportada (Tabela 2): as ocorrentes em florestas estacionais decidual da APA Morro da Pedreira - FED (sete espécies); as ocorrentes em matas ciliares - MC (oito) e, por último, as ocorrentes nas florestas estacionais semidecidual - FES (com 12 espécies). Nessa última, supõe-se a provável ocorrência de um número ainda maior de espécies urticóides, na medida em que forem aumentados os esforços de coletas e estudos exploratórios nos estratos herbáceos e arbustivos, uma vez que as expedições realizadas a área tinha como foco o levantamento das espécies com PAP $\geq 15 \mathrm{~cm}$.

Com relação à biogeografia, de modo geral as espécies de Rosales urticódes encontradas na Serra do Cipó são de ampla distribuição geográfica. Algumas espécies como Ficus calyptroceras, Celtis iguanaea e Trema micrantha são comuns ao longo das florestas decidual e semidecidual do leste brasileiro. Embora as espécies urticóides sejam geralmente de ampla distribuição, algumas espécies de Dorstenia apresentam distribuição restrita. No entanto, no presente trabalho nenhuma espécie apresenta restrita a Serra do Cipó. 
Tabela 3: Habitats preferenciais das espécies do clado urticóide ocorrentes na Serra do Cipó, Minas Gerais.

\begin{tabular}{|c|c|c|c|c|c|}
\hline & HAB & S PR & $\mathrm{NCl}$ & & \\
\hline FAMILIAS & ESPÉCIES & FED & CE & MC & FES \\
\hline \multirow{2}{*}{ CANNABACEAE } & Celtis iguanaea & $\mathrm{X}$ & & & $\mathrm{X}$ \\
\hline & Trema micrantha & $\mathrm{x}$ & & & \\
\hline \multirow{11}{*}{ MORACEAE } & Brosimum gaudichaudii & & $X$ & & $\mathrm{X}$ \\
\hline & Dorstenia brasiliensis & & & $X$ & \\
\hline & Ficus calyptroceras & $\mathrm{X}$ & & & \\
\hline & F. gomelleira & & & & $\mathrm{X}$ \\
\hline & F. obtusifolia & & & $X$ & $\mathrm{X}$ \\
\hline & F. obtusiuscula & & & $X$ & $\mathrm{X}$ \\
\hline & F. pertusa & & & $X$ & \\
\hline & Helicostylis tomentosa & & & & $\mathrm{X}$ \\
\hline & Maclura tinctoria & & & & $\mathrm{X}$ \\
\hline & Pseudolmedia laevigata & & & $X$ & \\
\hline & Sorocea guilleminiana & $\mathrm{X}$ & & & $\mathrm{X}$ \\
\hline \multirow{7}{*}{ URTICACEAE } & Boehmeria caudata & & & $X$ & \\
\hline & Cecropia hololeuca & & & & $\mathrm{X}$ \\
\hline & Cecropia pachystachya & $\mathrm{x}$ & & $X$ & $\mathrm{X}$ \\
\hline & Coussapoa microcarpa & & & $X$ & $\mathrm{X}$ \\
\hline & Pilea microphylla & $\mathrm{X}$ & & & \\
\hline & Pourouma guianensis & & & & $\mathrm{X}$ \\
\hline & Urera baccifera & $\mathrm{X}$ & & & \\
\hline
\end{tabular}

Legenda: FED - Floresta Estacional Decidual da APA Morro da Pedreira; CE Cerrado; MC - Mata Ciliar; FES - Floresta Estacional Semidecidual da Serra do Cipó.

No presente estudo do clado urticóide da Serra Cipó, características como hábito, tipos de inflorescências, forma da folha, presença e forma das glândulas foliares e dos cistólitos, número e forma de estames e estigmas, além das estípulas, brácteas e flores, mostraram-se importantes para a distinção de suas espécies dada a sua variabilidade e constância entre seus grupos. 
Ao longo do trabalho encontraram-se grande dificuldade na identificação e delimitação em vários de seus táxons, principalmente nas espécies dos gêneros Ficus e Celtis. A análise de vários materiais e de fotos de alguns dos materiais-tipo permitiu apreciar uma ampla variabilidade morfológica em diversos atributos vegetativos e mesmo reprodutivos de cada espécie, tanto na área de estudo, como em outras áreas.

Apesar de adotarmos aqui trabalhos de revisões taxonômicas e conceitos e delimitações de espécies de autores como Berg (1972, 1978a e 2001), Berg \& Dahlberg (2001) e Berg \& Franco-Rosselli (2005), observa-se que são muitos os muitos problemas nomenclaturais e insuficiências em algumas circunscrições, seja devido a discordâncias entre os autores, seja pelo fato de que o comportamento das espécies estudadas aqui não se encaixa integralmente nos delineamentos propostos nos estudos disponíveis. Dessa forma, verifica-se que o grupo urticóide necessita ainda de muito esforço de campo, de estudos de revisão e de incremento no número e tipos de análises morfológicas e anatômicas. Também novos estudos filogenéticos, que envolvam o maior número de caracteres morfológicos e moleculares possíveis, que sejam preferencialmente interdisciplinares, deverão contribuir para o progresso do conhecimento e conservação desse importante grupo de plantas.

Ao concluir o presente trabalho, almeja-se ter alcançado o objetivo de incrementar e aprimorar o conhecimento do clado urticóide, e que os resultados aqui apresentados possam servir de base para estudos ulteriores preconizados acima. 


\section{REFERÊNCIAS BIBLIOGRÁFICAS:}

ALLEN, P.H. 1943. Poisonous and injurious plants of Panama. J. Trop. Med. 23(suppl.): 3-76.

ALMEIDA, S.P., PROENÇA, C.E.B., SANO, S.M. \& RIBEIRO, J.F. 1998. Cerrado: espécies vegetais úteis. Planaltina, Embrapa-CPAC.

ANDRADE, J.C. \& CARAUTA, J.P.P. 1982. The Cecropia - Azteca Association: A Case of Mutualism? Biotropica 14(1): 15-0.

ANDRADE-LIMA, D. 1977. A flora de áreas erodidas de calcário Bambuí, em Bom Jesus da Laba, Bahia. Revista Brasil Biol. 37(1): 179-194.

APG. 1998. An ordinal classification for the families of flowering plants. Ann. Missouri Bot. Gard. 85: 531-553.

ARRUDA, V.L.V. \& SAZIMA, M. 1988. Polinização e reprodução de Celtis iguanaea (Jacq.) Sarg. (Ulmaceae), uma espécie anemófila. Revista Brasil. Bot. 11(1/2): 101-113.

AUBLET, J.B.C.F. 1775. Histoire des plantes de Guiane française, v. 2. London \& Paris. Pp. 952.

BAEHNI, C. 1936. Les Celtis Sub-Américains. Candollea 7: 189-214.

BARROSO, G.M., MORIN, M.P., PEIXOTO, A.L. \& ICHASO, C.L.F. 1999. Frutos e sementes: morfologia aplicada à sistemática de dicotiledôneas. Editora da Universidade Federal de Viçosa, UFV. Viçosa. Pp. 443.

BATTILANI, J.L., SANTIAGO, E.F. \& SOUZA, A.L.T. 2006. Morfologia de frutos, sementes e desenvolvimento de plântulas e plantas jovens de Maclura tinctoria

(L.) D. Don. Ex Steud. (Moraceae). Acta Bot. Brasil. 20(3): 581-589.

BECHTEL, A.R. 1921. The floral anatomy of the Urticales. Amer. J. Bot. 8: 386-410.

BELL, A.B. 1993. Plant form: an illustrated guide to flowering plant morphology. Oxford University Press, Oxford.

BENOIST, R. 1922. Descriptions d'espèces nouvelles du genre Pourouma (Moracées). Bull. Mus. Natl. Hist. Nat., Paris 28: 318-321.

BENOIST, R. 1924. Descriptions d'espèces nouvelles de Phanérogames de la Guyane française. Bull. Mus. Natl. Hist. Nat., Paris 30: 103-105. 
BENSON, W.W. 1985. Amazon ant-plants. In G.T. Prance \& T.E. Lovejoy (eds.) Key Environments: Amazonia. Pergamon Press, Oxford. Pp. 239-266.

BERG, C.C., AVILA, M.V. \& KOOY, F. 1984. Ficus species of Brazilian Amazônia and the Guianas. Acta Amazon. Supl. 14(1/2): 159-194.

BERG, C.C., AKKERMANS, R.W.A.P. \& HEUSDEN, E.H.van. 1990. Cecropiaceae:

Coussapoa and Pouroma, with an introduction to the family. Fl. Neotrop. Monogr. 51: 1-208.

BERG, C.C. \& DAHLBERG, S.V. 2001. A revision of Celtis, subg. Mertensia (Ulmaceae). Brittonia 53(1): 66-81.

BERG, C.C. \& FRANCO-ROSSELLI, P. 1993. Cecropiaceae. In G. Harling \& L. Andersson (eds.) Flora of Ecuador. Berlings. Arlöv. Pp. 48-59.

BERG, C.C. \& FRANCO-ROSSELLI, P. 2005. Cecropia. Fl. Neotrop. Monogr. n. 94:1230.

BERG, C.C. \& HEUSDEN, E.C.H.van. 1988. Studies on the flora of the Guianas 36. New taxa and combinations in Pourouma (Cecropiaceae). Proc. Kon. Ned. Akad. Wetensch., Ser. C, 91(2): 105-116.

BERG, C.C. \& KOOY, F. 1982. Three new species of Pourouma (Cecropiacea) of the Guiana Region. Brittonia 34(1):36-41.

BERG, C.C. \& SIMONIS, J.E. 1981. The Ficus flora of Venezuela: five species complexes discussed and two new species described. Ernstia 6: 1-12.

BERG, C.C. \& SIMONIS, J.E. 2000. Moraceae. In Riina, R (ed.) Flora de Venezuela. Moraceae-Cecropiaceae. Fundación Instituto Botánico de Venezuela, Caracas, p.5-189.

BERG, C.C. \& VILAVICCENCIO, X. 2004. Taxonomic studies on Ficus (Moraceae) in the West Indies, extra-Amazonian Brazil, and Bolívia. Ilicifolia 5: 1-177.

BERG, C.C. 1972. Olmedieae, Brosimeae (Moraceae). Fl. Neotrop. Monogr. n. 7: 1228.

BERG, C.C. 1975. Coussapoa. In J. Lanjouw \& A.L. Stoffers (eds.) Flora of Suriname 5(1): 279-286. Leiden.

BERG, C.C. 1977b. Abscission of anthers in Cecropia Loefl. Brief communication. Acta Bot. Neerl. 26: 417-419.

BERG, C.C. 1978a. Cecropiaceae a new family of the Urticales. Taxon 27: 39-44. 
BERG, C.C. 1978b. Espécies de Cecropia da Amazônia brasileira. Acta Amazon. 8: 149-182.

BERG, C.C. 1989. Systematics of Urticales. In Crane, P.R. \& Blackmore, S. (eds.)

Evolution, systematics, and fossil history of the Hamamelidae 2, 'Higher'

Hamamelidade. Claredon Press, Oxford. Pp. 193-220.

BERG, C.C. 1990. Differentiation of flowers and inflorescences of Urticales in relation to the protection against breeding insects and to pollination. Sommerfeltia 11: 13-34.

BERG, C.C. 1996. Cecropia (Cecropiaceae) no Brasil, ao Sul da Bacia Amazônica. Albertoa 4(16): 213-221.

BERG, C.C. 1998. Cecropiaceae. In P.E. Berry, B.K. Holst \& K. Yatskievych (eds.) Flora of the Venezuelan Guayana, vol. 4. Missouri Botanical Garden, St. Louis. Pp. 174-190.

BERG, C.C. 2001. Moreae, Artocapeae, and Dorstenia (Moraceae) with introductions to the family and Ficus and with additions and corrections to Flora Neotropica Monograph 7. Fl. Neotrop. Monogr. 83: 1-346.

BERTONI, J.E.A., MARTINS, F.R., MORAES, J.L. \& SHEPHERD, G.J. 1988. Vomposição florística e estrutura fitossociológica do Parque de Vacununga, Santa Rita do Passa Quatro, São Paulo, gleba Praxides. Bol. Téc. Inst. Flor., São Paulo 42: 149-170.

BRANDÃO, M. \& BRANDÃO, H. 1995. Reserva Biológica Municipal de Santa Rita do Sapucaí, MG - II: composição florística. Daphne 5(2): 5-16.

BRIDSON, G.D.R. \& SMITH, E.R. (eds.), 1991. B-P-H/S. Botanico-PeriodicumHuntianum/Supplementum. Pittsburgh, Pennsylvania: Hunt Institute for Botanical Documentation. p. 1068.

BRUMMITTT, R.K. \& POWEL, C.E. 1992. Authors of plant names. Royal Botanic Gardens, Kew.

BURGER, W.C. 1977. Flora Costaricensis: Moraceae. Fieldiana Bot. 40: 95-215.

BURGER, W.C., LANJOUW, J. \& BOER, J.G.W. 1962. The genus Sorocea St. Hil. (Moraceae). Acta Bot. Neerl. 11: 428-477.

CARAUTA, J.P.P. 1968. Catalogo dos gêneros de Moraceae do Brasil. Imprensa Universitária do Pará, Belém. 
CARAUTA, J.P.P. 1974. Índice das Ulmaceae do Brasil. Rodriguésia 27(39): 99-134. CARAUTA, J.P.P. 1976. Dorstenia L. (Moraceae) do Brasil e países limítrofes. Dissertação de Mestrado. Universidade Federal do Rio de Janeiro, Rio de Janeiro.

CARAUTA, C.C. 1978. Dorstenia do Brasil e países limítrofes. Rodriguésia 29(44): 53233.

CARAUTA, J.P.P. 1987. Moraceae. In A.M. Giulietti, N.L. Menezes, J.R. Pirani, M. Meguro \& M.G.L. Wanderley (eds.), Flora da Serra do Cipó, Minas Gerais: caracterização e lista das espécies. Bol. Bot. Univ. São Paulo 9: 79.

CARAUTA, J.P.P. 1987. Ulmaceae. In A.M. Giulietti, N.L. Menezes, J.R. Pirani, M. Meguro \& M.G.L. Wanderley (eds.), Flora da Serra do Cipó, Minas Gerais: caracterização e lista das espécies. Bol. Bot. Univ. São Paulo 9: 100.

CARAUTA, J.P.P. 1989. Ficus (Moraceae) no Brasil: conservação e taxonomia. Albertoa 2: 1-365.

CARAUTA, J.P.P. 1993. Moraceae da Reserva Florestal Estadual da Vista Chinesa, Rio de Janeiro. Albertoa 3(19): 193-224.

CARAUTA, J.P.P. 1996. Moráceas do Estado do Rio de Janeiro. Albertoa 4(13): 145194.

CARAUTA, J.P.P. \& SCHREIBER, A. 1977. Cecropia pachystachya Trécul: descrição da árvore masculina. Anais do XXIV Congresso Nacional de Botânica, Pelotas. Pp. 29-33.

CARAUTA, J.P.P. \& DIAZ, B.E. 2002a. Figueiras no Brasil. Editora UFRJ, Rio de Janeiro. p. 211.

CARAUTA, J.P.P. \& DIAZ, B.E. 2002b. Ficus gomelleira Kunth (Moraceae): descrição latina do sicônio e comentários sobre o autor. Albertoa, sér. Urticineae (Urticales) 10: $67-68$.

CARAUTA, J.P.P., ALBUQUERQUE, J.M., CASTRO, R.M. 2002. Dorstenia (Moraceae): notas complementares V. Albertoa ser. Urticineae (Urticales) 8: 53-56.

CARAUTA, J.P.P., ROMANIUC-NETO, S. \& SASTRE, C. 1996. Índice das espécies de Moráceas do Brasil. Albertoa 4(7): 77-96.

CARVALHO, P.E.R. 2003. Espécies Arbóreas Brasileiras. Curitiba, Embrapa Florestas. 
CASTRO, R.M. 2006. Flora da Bahia - Moraceae. Msc. Tese, Universidade Estadual de Feira de Santana, Feira de Santana, BA.

CASTRO, R.M. \& RAPINI, A. 2006. Four new species of Moraceae from Bahia, Brazil. Neodiversity 1:13-20.

CHEN, C.J. 1982. A monograph of Pilea (Urticaceae) in China. Bull. Bot. Research 2: 1-132.

CHEW, Wee-Lek. 1963. A revision of the genus Poikilospermum. Gard. Bull. Singapure 20: 1-104.

CORNER, E.J.H. 1962. The classification of Moraceae. Gard. Bull. Singapure 19(2): 187- 252.

CORRÊA, M.P. \& PENNA, A. 1969. Diccionário das plantas úteis do Brasil e das exóticas cultivadas. Imprensa Oficial, Rio de Janeiro 2: 324-325.

COSTA, F.N. 2001. Flora da Serra do Cipó, Minas Gerais: Blastocaulon Ruhland, Paepalanthus subg. Thelxinoe Ruhland e Paepalanthus subg. Paepalocephalus Ruhland pro parte (Eriocaulaceae). Dissertacão de Mestrado. Instituto de Biociências, Universidade de São Paulo, São Paulo.

CRESTANA, M.S.M. (org.), FORRETTI, A.R., TOLEDO FILHO, D.V., ÁRBOCZ, G.F., SCHMIDT, H.A.P. \& GUARDIA, J.F.C. 2006. Florestas - Sistemas de Recuperação com Essências Nativas, Produção de Mudas e Legislações. 2 ed. Campinas: CATI, 248p.

CROAT, T.B. 1978. Flora of Barro Colorado Island. Stanford University Press, Stanford, California. Pp. 339-342.

CRONQUIST, A. 1981. An Integrated System of Classification of Flowering Plants. Columbia University Press, New York.

CRONQUIST, A. 1988. The evolution and classification of flowering plants. New York Botanical Garden. New York.

CUATRECASAS, J. 1951. Moraceae. In J.A. Steyermark (ed.) Botanical exploration of Venezuela - I. Fieldiana Bot. 28(1): 210-304.

CUATRECASAS, J. 1954. Dos Moráceas y dos Compuestas nuevas de Venezuela. Bol. Soc. Venez. Ci. Nat. 15: 107-111.

CUATRECASAS, J. 1956a. Notas a Flora de Colombia, XIV. Revista Acad. Colomb. Ci. Exact. 9(36/37): 325-341. 
CUATRECASAS, J. 1956b. Moráceas nuevas de Colombia. Caldasia 7: 287-304.

CUATRECASAS, J. 1956c. Notas a la Flora de Venezuela. Bol. Soc. Venez. Ci. Nat. 17: 80-97.

CUATRECASAS, J. 1967. Moraceae. In J.A. Steyermark (ed.) Flora del Auyan-tepui. Acta Bot. Venez. 2(5-8): 202-205.

CUATRECASA, J. 1982. Miscellaneous notes on the neotropical flora, XIV. Phytologia 52: 157-159.

CUÉLLAR, H. S. 1967. Description of a pollen release mechanism in the flower of the Mexican hackberry tree, Celtis laevigata Southw. Naturalist 12: 471-474.

DAHLGREN, R. 1989. A revised system of classification of the angiosperms. Bot. J. Linn. Soc. 80:91-124.

DATWYLER, S.L. \& WEIBLEN, G.D. 2004. On the origin of the fig: phylogenetic relationships of Moraceae from $n d h F$ sequences. Amer. J. Bot. 91(5): 767-777.

DUCKE, A. 1932a. Neue Arten aus der Hylea Brasiliens. Notizbl. Bot. Gart. BerlinDahlem 11: 579-591.

DUCKE, A. 1932b. Espèces nouvelles de plantes de l'Amazonie Brésilienne. Bull. Mus. Hist. Nat., Paris, Sér. 2, 4: 720-749.

DUCKE, A. 1947. New forest trees and climbers of the Amazon. Trop. Woods 90: 7-30.

DURIGAN, G. \& NOGUEIRA, J.C.B. 1990. Recomposição de matas ciliares. Instituto Florestal. São Paulo, IF Série Registros 4.

ELIAS, T.S. 1970. The genera of Ulmaceae in the Southeastern United States. J. Arnold Arbor. 51: 18-40.

ENGLER, A. 1907. Syllabus der Pflanzenfamilien. Eine Übersicht über das gesamte Pflanzensystem MIT berücksichtigung der Medzinal und Nutzpflanzen. Borntraeger, Berlin.

FALCÃO, M.A. \& LLERAS, E. 1980. Aspectos fenológicos, ecológicos e de reprodutividade do Mapati (Pourouma cecropiifolia Mart.). Acta Amazon. 10(4): 711-724.

FARIA, E. 1967. Dicionário escolar latino-português. Departamento Nacional de Educação, Ministério da Educação e Cultura.

FONT QUER, P. F. 1989. Diccionario de Botánica. Ed. Labor, Barcelona. 
FRANCIS, J.K. \& RODRíGUEZ, A. 1993. Seeds of Puerto Rican trees and schrubs: second installment. U.S. Dep. Agric., Forest service, Research Note SO-374. Southern Forest Experiment Station, New Orleans, 5p.

FRIIS, I. 1993. Urticaceae. In KUBITZKI, K, ROHWER, J.G. \& BITTRICH, V. (eds.), The families and genera of vascular plants. v.2., Berlin: Springer-Verlag, 653p.

GANGADHERA, M. \& INAMDAR, J.A. 1977. Trichomes and stomata, and their taxonomic significance in the Urticales. Pl. Syst. Evol. 127: 121-137.

GAVILANES, M.L. \& BRANDÃO, M. 1994. Composição florística das áreas recobertas pela Caatinga na área da SUDENE. Informe Agropecuário, Belo Horizonte, 17(181): 20-33

GIULIETTI, A.M. \& PIRANI, J.R. 1988. Patterns of geographic distribution of some plant species from the Espinhaço Range, Minas Gerais and Bahia, Brasil. In P.E. Vanzolini, \& W.R. Heyer (eds). Proceedings of a workshop on Neotropical Distribution Patterns. Academia Brasileira de Ciências. Rio de Janeiro. p. 39-69.

GIULIETTI, A.M., MENEZES, N.L., PIRANI, J.R., MEGURO, M. \& WANDERLEY, M.G.L., 1987. Flora da Serra do Cipó, Minas Gerais: caracterização e lista das espécies. Bol. Bot. Univ. São Paulo 9: 1-151.

GONTIJO, A.H.F. 1993. O relevo da Serra do Cipó, Minas Gerais, Espinhaço meridional. Dissertação de Mestrado. Instituto de Biociências, Universidade de São Paulo, São Paulo.

GRANVILLE, J.J. 1971. Notes sur La biologie florale de quelques espèces du genre Dorstenia (Moracées). Cah. Ortom, sér. Biol. 15: 61-97.

GROPPO, M. \& PIRANI, J.R. 2005. Flora da Serra do Cipó, Minas Gerais: Aquifoliaceae. Bol. Bot. Univ. São Paulo 23(2): 257-265.

GUÉRIN, P. 1923. Les urticacées: cellules à mucilage, lactifères et canaux sécréteurs. Bull. Soc. Bot. Fr. 70: 125-136, 207-215, 255-263.

HAGEN, V.W. von. 1943. Mexican paper-making plants. J. New York Bot. Gard. 44: 110.

HARRIS, J.G. \& HARRIS, M.W. 1997. Plant identification terminology: an illustrated glossry. Spring Ann. Bot. 41: 1233-1258.

HENDERSON, A. 2005. The methods of herbarium Taxonomy. Syst. Bot. 30(2): 456469. 
HICKEY, L.J. 1973. A revised classification of architectureof dicotyledonous leaves. Amer. J. Bot. 60(1): 17-33.

HOLMGREN, P.K., HOLMGREN, N.H. \& BARNETT, L.C. (eds.) 1990. Index Herbariorum. Part 1: The herbaria of the world. Ed. 8. New York: New York Botanical Garden.

HUMPHRIES, C.J. \& BLACKMORE, S. 1989. A review of the classification of the Moraceae. In P. R. Crane \& S. Blackmore (eds.). Evolution, systematics, and fossil history of the Hamamelidae, vol. 2, higher Hamamelidae, p. 264-277. Claredon Press, Oxford, UK.

HUNZIKER, A.T. \& DOTTORI, N.M. 1976. Contribución al conocimiento sobre los talas (Celtis, Ulmaceae) de Argentina, com especial referencia a la region Mediterrânea. Kurtiziana 9: 103-140.

INDEX KEWENSIS: on compact disc. Royal Botanic Garden, Kew. 1997. versão 2.0 para IBM PC. Oxford University Press, Oxford.

IPNI - The International Plant Names Index. 2008. Published on the Internet http://www.ipni.org [accessed 20 may 2008].

JACOMASSI, E., MOSCHETA, I.S. \& MACHADO, S.R. 2007. Morfoanatomia e histoquímica de Brosimum gaudichaudii Trécul (Moraceae). Acta Bot. Brasil 21(3): 575-597.

JACQUIN, N. J. von. 1760. Enumeratio systematica plantarum. Theodorus Haak, Leiden.

JANZEN, D.H. 1973. Dissolution of mutualism between Cecropia and its Azteca ants. Biotropica 5: 15-28.

JUDD, W.S., SANDERS, R. W., \& DONOGHUE, M.J. 1994. Angiosperm family pairs: Preliminary phylogenetic analyses. Harvard Papers Botany 5:1-51.

JUDD, W. S., CAMPBELL, C.S., KELLOG, E.A., STEVENS, P.F. \& DONOGHUE, M. 2002. Plant Systematics: a phylogenetic approach. Ed. 2. Sinauer Associates, Sunderland, Massachusetts.

KING, L.C. 1956. A geomorfologia do Brasil Oriental. Revista Brasil. Geogr. 18: 147265.

KLOTZSCH, J.F. 1847. Beiträge zu einer Flora de Aequinotial-Gegenden: Artocarpeae. Linnaea 20: 523-525. 
KUBITZKI, K., J.G. ROHWER \& BITTRICH, V. (eds.). 1993. The families and genera of vascular plants - II Flowering plants - Dicotyledons, Magnoliid, Hammelid and Caryophyllid families. Berlin, Springer-Verlag, p. 674.

KUHLMANN, M. \& KÜHN, E. 1947. A flora do distrito de Ibiti: I - inventário florístico; II - Subsídios para o estudo da biocenose regional. sér. b, São Paulo: Instituto de Botânica, 221p.

KRAVTSOVA, T.I. \& OSKOLSKI, A.A. 2007. Cladistic analysis of the Urticaceae, Cecropiaceae and Moraceae (Urticales) based on carpological characters. Bot. Zhurn. 92: 613-640.

LACHANCE, M.A., KLEMENS, J.A., BOWLES, J.M. \& JANZEN, D.H. 2001. The yeast community of sap fluxes of Costa Rican Maclura (Chlorophora) tinctoria and description of two new yeast species, Candida galis and Candida ortonii. FEMS Yeast Research 1: 87-92.

LAMARCK, J.B.A.B.M. 1789. Encyclopédie methodique. Botanique 3. Panckoucke, Paris.

LEITÃO, M.M.N. 1984. Estudo comparativo do sub-gênero Pharmacosycea no Brasil. 1Ficus obtusiuscula (Miq.) Miq. Bradea 4(6): 31-40.

LETOUZEY, R. 1972. Manual of forest botany, Tropical Africa. Centre Technique Forestier Tropical (France).

LIMA, V.C., GODOY, C.E.C. 1987. Urticaceae. In A.M. Giulietti, N.L. Menezes, J.R. Pirani, M. Meguro \& M.G.L. Wanderley (eds.), Flora da Serra do Cipó, Minas Gerais: caracterização e lista das espécies. Bol. Bot. Univ. São Paulo 9: 101.

LITTLE Jr, E.L., WOODBURY, O. \& WADSWORTH, F.H. 1988. Arboles de Puerto Rico y las Islas Virgenes. v.2, U.S. Dep. Agric. Handb., Washington D.C. 449-S, $1177 \mathrm{p}$.

LITTLE Jr., E.L., WOODBURY, R.O., WADSWORTH, F.H. 1974. Mulberry Family (Moraceae). In LITTLE Jr., E.L., WOODBURY, R.O., WADSWORTH, F.H. (orgs.) Trees of Puerto Rico and the Virgin Islands. U.S. Dep. Agric. Handb., Washington D.C. v. 2, p.112-125.

LOFGREN, A. 1917. Manual das famílias Naturais Phanerogamas. Rio de Janeiro. Ed. Imprensa Nacional. p. 144-146. 
LORENZI, H. 2002. Árvores brasileiras: manual de identificação e cultivo de plantas arbóreas do Brasil. 2ed. vol. 2, Nova Odessa, SP: Instituto Plantarum. $\quad 352 \mathrm{p}$.

LORENZI, H. \& MATOS, J.A. 2002. Plantas medicinais no Brasil: nativas e exóticas cultivadas. São Paulo, Instituto Plantarum, Nova Odessa.

LORENZI, H. \& SOUZA, H.M. 2001. Plantas Ornamentais no Brasil: arbustivas, herbáceas e trepadeiras. 3 ed. Nova Odessa, SP: Instituto Plantarum. 1088p.

LOUREIRO, J. 1790. Flora Cochinchinensis ... Ulyssipone, 4: 562.

MACBRIDE, J.F. 1930. Peruvian Spermatophytes. 4. Other Peruvian plants, chiefly new species. Publ. Field Mus. Nat. Hist., Bot. Ser. 8(2): 113-130.

MACBRIDE, J.F. 1937. Flora of Peru. Moraceae. Publ. Field Mus. Nat. Hist., Bot. Ser. 13(2.2): 274-331.

MARCHIORETTO, M.S. 1988. Estudo taxonômico das espécies dos gêneros Celtis e Trema (Ulmaceae) no Rio Grande do Sul. Pesquisas Bot. 39:49-80.

MARIANO, G., CRESTANA, C.S.M., BATISTA, E.A., GIANNOTTI, E. \& COUTO, H.T.Z. 1998. Regeneração natural em área à margem de represa no município de Piracicaba, SP. Rev. Inst. Flor. 10(1): 81-93.

MARTINS, V.L.C., CARAUTA, J.P.P. \& SILVA, I.M. 2007. Moraceae. In Rizzo, J.A. (ed.) Flora dos Estados de Goiás e Tocantins Coleção Rizzo, v.37, Goiânia: PRPPG/UFG, 116p.

MARTIUS, C.F.P. 1843. Systema materiae medicae vegetabilis Brasiliensis. Leipzig.

MCNEILL, J., BARRIE, F.R., BURDET, H.M., DEMOULIN, V., HAWKSWORTH, D.L., MARHOLD, K., NICOLSON, D.H., PRADO, J., SILVA, P.C., SKOG, J.E., WIERSEMA, J.H. \& TURLAND, N.J. 2006. International Code of Botanical Nomenclature (Vienna Code). Liechtenstein: A.R.G. Gantner Verlag. p. 568.

MEGURO, M., PIRANI, J.R., MELLO-SILVA, R. \& CORDEIRO, I. 2007. Composição florística e estrutura das florestas estacionais decíduas sobre calcário a oeste da Cadeia do Espinhaço, Minas Gerais, Brasil. Bol. Bot. Univ. São Paulo 25(2): 147171.

MELLO-FILHO, L.E. 1963. Introdução ao estudo do gênero Ficus (Moraceae) na Guanabara e arredores. Tese de Doutorado. Universidade do Estado da Guanabara, Rio de Janeiro. 
MELLO-FILHO, L.E., NEVES, L.J., CARAUTA, J.P.P. \& DIAZ, B.E. 2001. Morfologia de certos sicônios de Ficus (Moraceae). Albertoa, série Urticineae (Urticales) 3: 1820.

MENDONÇA-SOUZA, L.R. 2006. Ficus (Moraceae) no Estado de São Paulo. Dissertação de Mestrado, Instituto de Botânica da Secretaria de Estado do Meio Ambiente, São Paulo, SP.

MILDBRAED, J. 1942. Moraceae II. In L. Dies, Neue Arten aus Ecuador. Notizbl. Bot. Gart. Berlin-Dahlem 10: 783-785.

MIQUEL, F.A.W. 1847. Prodromus monographie Ficuum. London J. Bot. 6: 514-588.

MIQUEL, F.A.G. 1853. Artocarpeae. In C.F.P. Martius (ed.). Flora Brasiliensis. Frid. Fleischer, Leipzig. vol. 4, pars. 1, p. 79-170.

MIQUEL, F.A.G. 1853. Chlorantaceae, Piperaceae, Urticineae. In C.F.P. Martius (ed.) Flora Brasilienis. Lipsiae, Frid. Fleischer, vol. 4, pars 1, p. 170-182, tab. 62-63.

MONRO, A.K. 2004. Three new species, and three new names in Pilea (Urticaceae) from New Guinea. Kew Bull. 59: 573-579.

MONRO, A.K. 2006. The revision of species-rich genera: a phylogenetic framework for the strategic revision of Pilea (Urticaceae) based on cpDNA, nrDNA, and morphology. Amer. J. Bot. 93(3): 426-441.

MOREIRA, A.A.N. 1965. Relevo. In Geografia do Brasil - grande região Leste. IBGE, Rio de Janeiro 5: 5-54.

MOREIRA, A.A.N. \& CAMELIER, C. 1977. Relevo. In Geografia do Brasil - região Sudeste. IBGE, Rio de Janeiro 3: 1-50.

MÜLLER, F. 1880. Die Imbauba und ihre Beschützer. Kosmos 8: 109-116.

NASCIMENTO, H.E.M., DIAS, A.S., TABANEZ, A.A.J. \& VIANA, V.M. 1999. Tree population and dynamics of a semidecidous seasonal Forest fragment in the Piracicaba region, Sao Paulo State, Brazil. Revista Brasil Biol. 59(2): 329-342.

NEE, M. 1984. Ulmaceae. In A. Gómez-Pompa (ed.) Flora de Veracruz. Veracruz, Instituto Nacional de Investigaciones sobre Recursos Bióticos, Fasc. 40, 38p.

NEVLING Jr., L.I. 1960. Flora of Panama: Ulmaceae. Ann. Missouri Bot. Gard. 47: 105113.

NIMER, E. 1989. Climatologia do Brasil. Rio de Janeiro. Instituto Brasileiro de Geografia e Estatística - IBGE. p. 257. 
NYLIN, S. \& WAHLBERG, N. 2008. Does plasticity drive speciation? Host-plant shifts and diversification in nymphaline butterflies (Lepidoptera: Nymphalidae) during the Tertiary. Biol. J. Linn. Soc. 94: 115-130.

O'DOWD, D.J. 1982. Pearl bodies as ant food: na ecological role of some leaf emergences of tropical plants. Biotropica 14(1): 40-49.

OLIVEIRA FILHO, A.T. 2006. Catálogo de árvores nativas de Minas Gerais: mapeamento e inventário da flora nativa e dos reflorestamentos de Minas Gerais. Lavras, Editora UFLA. 423p.

OMORI, Y., AND TERABAYASHI, S. 1993. Gynoecial vascular anatomy and its systematic implications in Celtidaceae and Ulmaceae (Urticales). J. Pl.

Sci. Res. 106: 249-258.

PAULA, J.E. \& ALVES, J.L.H. 1997. Madeiras nativas - Anatomia, dendrologia, dendrometria, produção e uso. Brasília, Fundação Mokiti Okada - MOA.

PIO-CORRÊA, M. 1984. Dicionário de Plantas Úteis do Brasil. vol. 2-3, Rio de Janeiro, Ministério da Agricultura. Instituto Brasileiro de Desenvolvimento Florestal.

PIRANI, J.R. 2003. Vegetação campestre da Cadeia do Espinhaço, MG e BA: origem, estrutura e diversidade. In Desafios da botânica no novo milênio: inventário, sistematização e conservação da diversidade vegetal. $54^{\circ}$ Congresso Nacional de Botânica, Belém, p. 175-177.

PLANCHON, J.E. 1873. Ulmaceae. In A. De Candolle (ed.) Prodomus systematis naturalis regni vegetabilis 17: 151-210.

POTT, A. \& POTT, V.J. 1994. Plants of Pantanal. Pantanal, Embrapa.

RADFORD, A.E, DICKISON, W.C., MASSEY, J.R. \& BELL, C.R. 1974. Vascular plant systematics. New York: Harper \& Row.

RAGUSA NETTO, J. 2002. Fruiting phenology and consumption by birds in Ficus calyptroceras (Miq.) Miq. (Moraceae). Braz. Jour. Biol. 62(2): 339-346.

RAPINI, A. 2000. Asclepiadoideae (Apocynaceae). Espinhaco Range, Minas Gerais, Brazil. In R.B. Foster (Coord.) Rapid color guide. Enviromental \& Conservation Programs, Field Museum. Chicago.

RAPINI, A. 2004. Classes or individuals? The Paradox of Systematics revised. Stud. Hist. Phil. Biol. \& Biomed Sci. 35:675-695. 
RENNER, O. 1907. Beiträge zur anatomie und systematiek der Artocarpeen und Conocephaleen, in besondere der Gattung Ficus. Bot. Jahrb. Syst. 39: 319-448.

RICHARDSON, J.E., FAY, M.F., CRONK, Q.C.B., BOWMAN, D., \& CHASE, M.W. 2000. A phylogenetic analysis of Rhamnaceae using $r b c \mathrm{~L}$ and $t r n \mathrm{~L}-\mathrm{F}$ plastid DNA sequences. Amer. J. Bot. 87: 1309-1324.

ROCHA, E.S.F., CARAUTA, J.P.P. \& LIMA, D.F. 2000. Ulmáceas do Estado do Rio de Janeiro: nota preliminar. Albertoa, série Urticineae, 2.

RODRIGUES, V.E.G. \& CARVALHO, D.A. 2001. Plantas medicinais no domínio dos cerrados. Lavras, Editora UFLA.

ROMANCZUK, M.C. \& MARTINEZ, M.A.P. 1978. Las especies del género Celtis en la flora argentina. Darwiniana 21(2-4): 541-577.

ROMANIUC NETO, S. 1996. Sorocea jureiana (Moraceae): a new specie from the southern of the Brazil. Albertoa 4(8): 97-100.

ROMANIUC-NETO, S. 1998. Biodiversité et spéciation dans lê Sud-Est du Brésil et dans le basin du fleuve Paraná: exemple de quelques espèces appartenant à un complexe du genre Sorocea A. St.-Hil. (Moraceae). Compt. Rend. Acad. Sci. Paris, sèr. 3, Sci. Vie. 327: 669-675.

ROMANIUC-NETO, S. 1999. Cecropioideae (C.C. Berg) Romaniuc-Neto stat. nov. (Moraceae - Urticales). Albertoa 4: 13-16.

RUSBY, H.H. 1910. New species from Bolivia, collected by R.S. Willians. Bull. New York Bot. Gard. 6: 487-517.

SANO, P.T. 1998. Flora da Serra do Cipó, Minas Gerais: Paepalanthus sect. Actinocephalus Koern. (Eriocaulaceae). Bol Bot. Univ. São Paulo 17: 187-205.

SATTARIAN, A. 2006. Contribution to the biosystematics of Celtis L. (Celtidaceae) with special emphasis on the African species. PhD Thesis Wageningen University, Wageningen.

SATTARIAN, A. \& van der MAESEN, L.J.G. 2005. Two new species of Celtis (Celtidaceae) from Australia and Madagascar. Blumea 50: 499-503.

SAVOLAINEN, V., CHASE, M.W., HOOT, S.B., MORTON, C.M., SOLTIS, D.E., BAYER, C., FAY, M.F., BRUIJN, A.Y., SULLIVAN, S. \& QIU, Y-L. 2000a. Phylogenetics of flowering plants based upon a combined analysis of plastid atpB and rbcL gene sequences. Syst. Bot. 49: 306-362. 
SAVOLAINEN, V., FAY, M.F., ALBACH, D.C., BACKLUND, A., van der BANK, M., CAMERON, K.M., JOHNSON, S.A., LLEDÓ, M.D., PINTAUD, J-C., POWELL, M., SHEAHAN, M.C., SOLTIS, D.E., SOLTIS, P.S., WESTON, P., WHITTEN, W.M., WURDACK, Y.J. \& CHASE, M.W. 2000b. Phylogeny of the Eudicots: a nearly complete familial analysis based on $r b c L$ gene sequences. Kew Bull. 55: 257-309.

SHU, P. 2003. Flora of China 5: 15-19.

SITES, J.W. \& MARSHALL. J.C. 2004. Perational criteria for delimiting species. Annual Rev. Ecol. Syst. 35: 199-227.

SMITH, S.A. \& DONOGHUE, M.J. 2008. Rates of molecular evolution are linked to life history in flowering plants. Science 322: 86-89.

SOEPADMO, E. 1977. Ulmaceae. Flora Malesiana 82: 31-76.

SOLTIS, D.E., SOLTIS, P.S., CHASE, M.W., MORT, M.E., ALBACH, D.C., ZANIA, M., SAVOLAINEN, V., HAHN, W.H., HOOT, S.B., FAY, M.F., AXTELL, M., SWENSEN, S.M., PRINCE, L.M., KRESS, W.J., NIXON, K.C. \& FARRIS, J.S. 2000. Angiosperm phylogeny inferred from 18S rDNA, rbcL, and atpB sequences. Bot. J. Linn. Soc. 133(1-4): 381-461.

SONG, B.H., WANG, X.-Q., LI, F.-Z. \& HONG, D.-Y. 2002. Further evidence for Paraphyly Celtidaceae from the chloroplast gen matK. Pt. Syst. Evol. 228:107115.

SOUZA, V.C. \& LORENZI, H. 2008. Botânica Sistemática: guia ilustrado para identificação das famílias de Fanerógamas nativas e exóticas do Brasil, baseado em APG II. Instituto Plantarum, Nova Odessa, SP. 673p.

STAFLEU, F.A. \& COWAN, R.S. 1973-1988. Taxonomic literature, vol. 1-7. Ed. Bohn, Scheltema \& Holkema, Utrech.

STANDLEY, P.C. 1919. Studies of tropical American phanerogams - n. 3. Countr. U.S. Natt. Herb 20(6): 173-220.

STANDLEY, P.C. 1937b. Flora of Costa Rica: Moraceae. Publ. Field Mus. Nat. Bot., Sér. 18(1): 378-392.

STEARN, W.T. 1980. Botanical latin. David \& Charles Pub, London. 
STEVENS, P.F. 2001 (-onwards). Angiosperm Phylogeny Website. Version 9, June 2008 [and more or less continuously updated since]. http://www.mobot.org/MOBOT/research/APweb/.

SWEITZER, E.M. 1971. Comparative Anatomy of the Ulmaceae. J. Arnold Arbor. 52: 523-585.

SYTSMA, K.J., MORAWETZ, J., PIRES, J.C. \& MORDEN, C. W. 2000. Phylogeny of the Urticales based on three molecular data sets, with emphasis on relationships within Urticaceae. Amer. J. Bot. 87(6, suppl.): 162.

SYTSMA, K. J., MORAWETZ, J., PIRES, J. C., NEPOKROEFF, M., CONTI, E., ZJHRA, M., HALL, J. C. \& CHASE, M. W. 2002. Urticalean rosids: Circumscription, rosid ancestry, and phylogenetics based on $r b c L, t r n L-F$, and $n d h F$ sequences. Amer. J. Bot. 89: 1531-1546.

TERABAYASHI, S. 1991. Vernation patterns in Celtidaceae and Ulmaceae (Urticales), and their evolutionary and systematic implications. Botanical magazine, Tokyo 104: 1-13.

THULIN, M.B., BREMER, B., RICHARDSON, J., NIKLASSON, M.F. Fay. \& CHASE, M. W. 1998. Family relationships pf the enigmatic rosid genera Barbeya and Dirachma from the Horn of Afica region. Plant Syst. Evol. 213: 103-119.

TODZIA, C.A. 1989. A revision of Ampelocera (Ulmaceae). Ann. Missouri Bot. Gard. 76(4): 1087-1102

TONIATO, M.T.Z. \& OLIVEIRA FILHO, A.T. 2004. Variations in tree community composition and structure in a fragment of tropical semideciduous forest in southeastern Brazil related to different human disturbance histories. Forest Ecol. and management 198: 319-339.

TORRES, R.B. \& LUCA, A.Q. 2005. Ulmaceae. In M.G.L. Wanderley, G.J. Shepherd, A.M. Giulietti \& T.S. Melhem (Eds.) Flora Fanerogâmica do Estado do São Paulo. RIMA, FAPESP. São Paulo, vol. 4, p. 361-369.

TRÉCUL, A. 1847. Sur la famille des Artocarpées. Ann. Sci. Nat. Bot., Sér. 3, 8: 38157.

UEDA, K., KOSUGE, K. \& TOBE, H. 1997. A molecular phylogeny of Celtidaceae and Ulmaceae (Urticales) based on rbcL nucleotide sequences. J. Pl. Res. 110: 171-178. 
Van VELZEN, R., BAKKER, F.T., SATTARIAN, A. \& van der MAESEN, L.J.G. 2006. Celtidaceae Evolutionary relationships. In A. SATTARIAN. Contribution to the biosystematics of Celtis L. (Celtidaceae) with special emphasis on the African species. PhD Thesis. Wageningen University, Wageningen.

VIANNA FILHO, M.D.M., CARRIJO, T.T., LACERDA, R.W. \& CARAUTA, J.P.P. 2005. Cecropia (Cecropiaceae): guia para coleta. Albertoa, série Urticineae (Urticales). Pp. 165-170.

VITTA, F.A. 1995. Composição florística e ecologia de comunidades campestres na Serra do Cipó, Minas Gerais. Tese de Doutorado. Universidade de São Paulo, Brasil. p. 111.

WEBERLING, F. 1989. Morphology of flowers and inflorescences. Cambridge: Cambridge University Press.

WHEELER, W.M. 1942. Studies of neotropical ant-plants. Bull. Mus. Comp. Zool. Harvard 90: 3-154.

WIEGRIEF, S.J., SYTSMA, K.J. \& GURIES, R.P. 1998. The Ulmaceae, one family or two? Evidence from chloroplast DNA restriction site mapping. Pt. Syst. Evol. 210: 249-270.

WIJMSTRA, T.A. 1967. A pollen diagram from the Upper Holocene of the Lower Magdalena Valley. Leidse Geol. Meded. 39: 261-267

WOLFE, J.A. 1974. Fossil forms of Amentiferae. Brittonia 25: 334-355.

WOODSON, R.E. \& SCHERY, R.W. 1960. Flora of Panama: Moraceae. Ann. Missouri Bot. Gard. 47(2): 114-178.

ZAVADA, M.S. \& KIM, M. 1996. Phylogenetic analysis of Ulmaceae. PI. Syst. and evol. 200: 13-20. 